\title{
Further chemistry of ruthenium alkenylacetylide complexes: routes to allenylidene complexes via a series of electrophilic addition reactions
}

Michael R. Hall, Marcus Korb, Stephen A. Moggach, Paul J. Low*

School of Molecular Sciences, University of Western Australia, 35 Stirling Highway, Crawley, 6009, WA, Australia.

Email paul.low@uwa.edu.ua

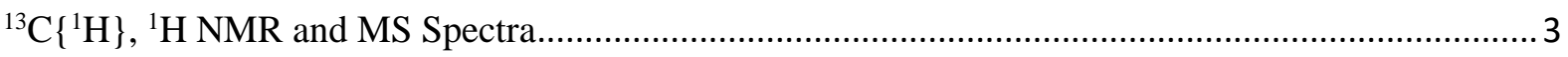

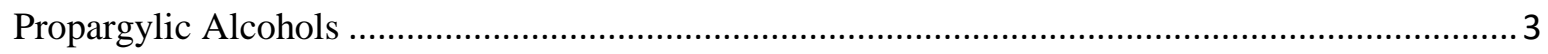

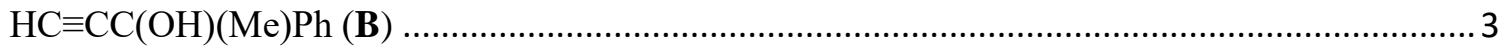

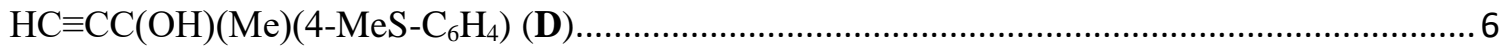

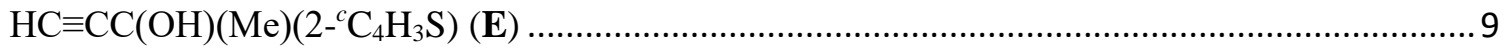

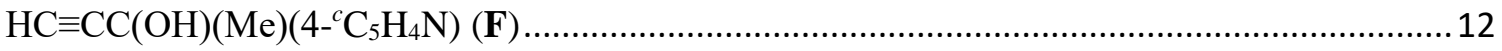

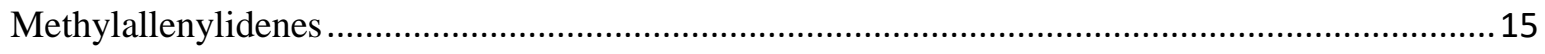

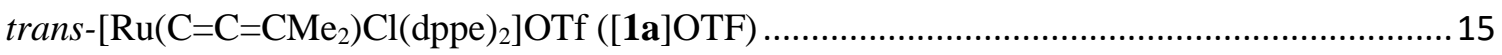

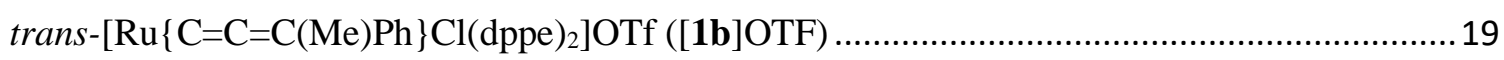

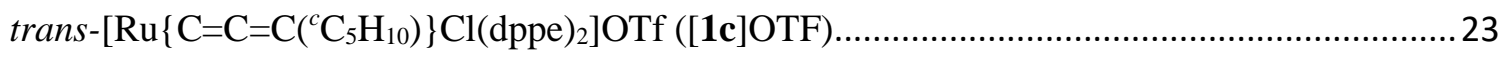

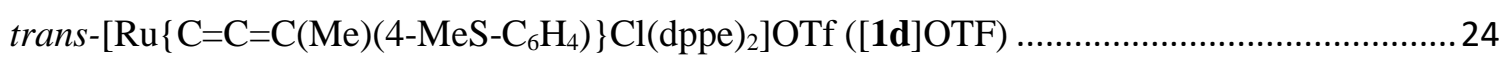

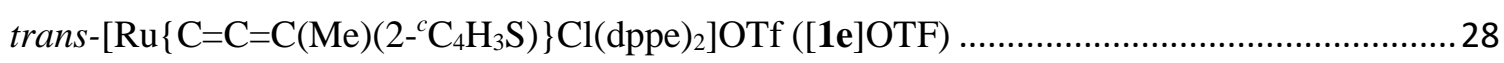

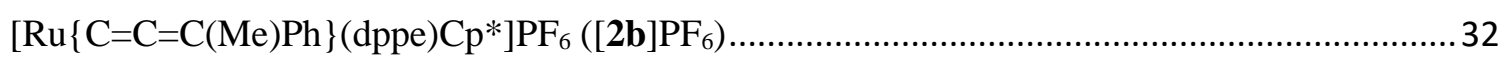

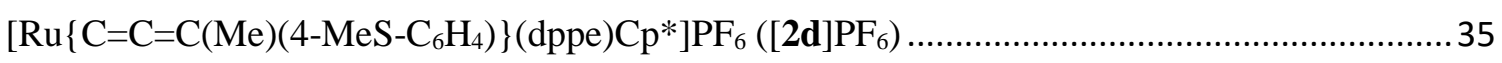

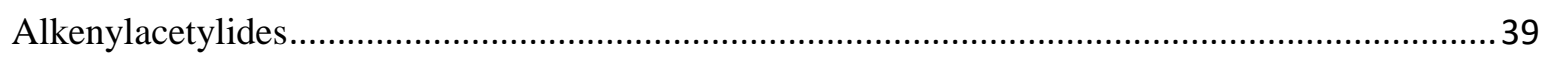

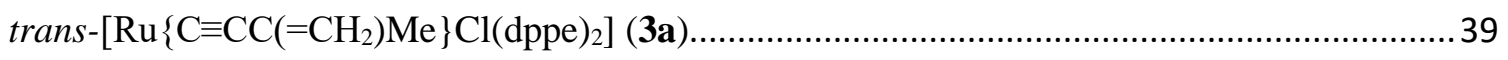

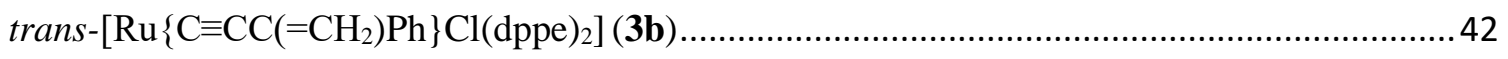

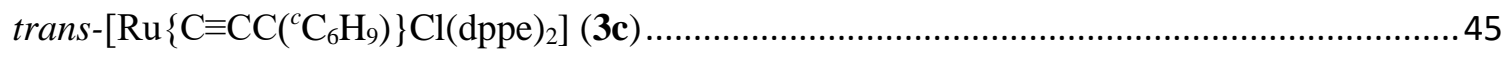

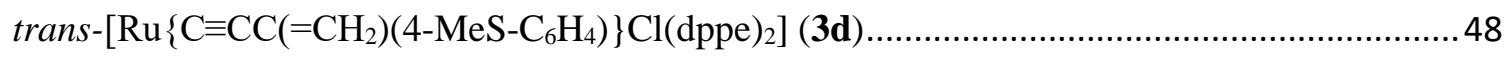

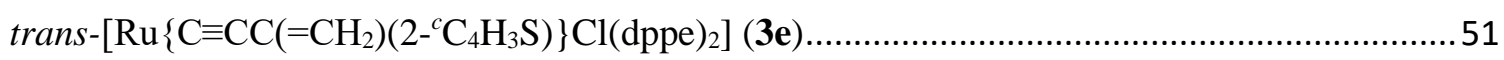

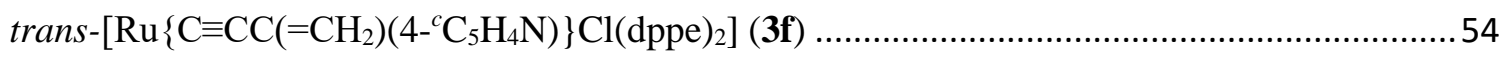

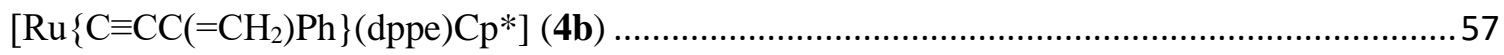

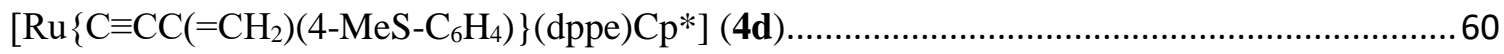

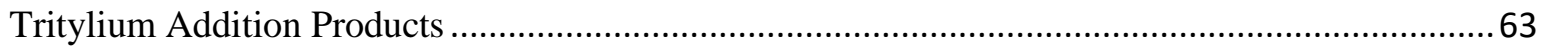

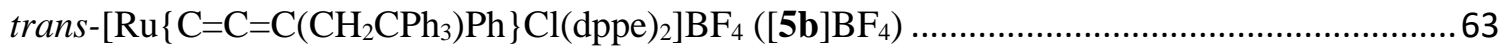




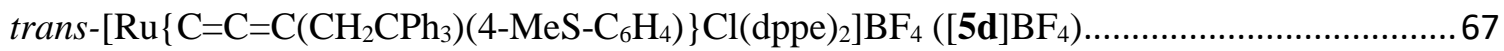

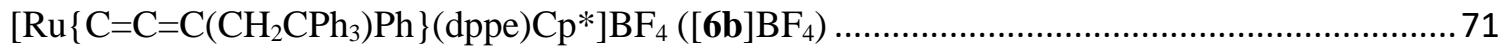

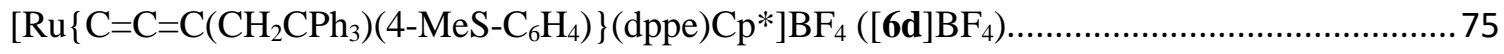

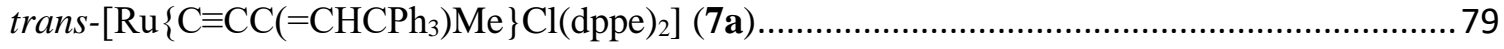

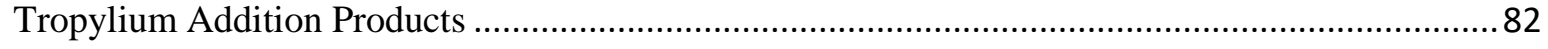

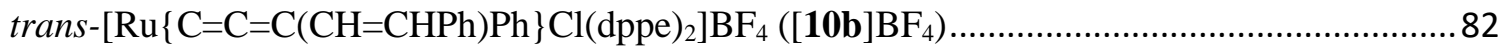

trans $-\left[\mathrm{Ru}\left\{\mathrm{C}=\mathrm{C}=\mathrm{C}(\mathrm{CH}=\mathrm{CHPh})\left(4-\mathrm{MeS}_{-} \mathrm{C}_{6} \mathrm{H}_{4}\right)\right\} \mathrm{Cl}(\mathrm{dppe})_{2}\right] \mathrm{BF}_{4}\left([\mathbf{1 0 d}] \mathrm{BF}_{4}\right) \ldots \ldots \ldots \ldots \ldots \ldots \ldots \ldots \ldots \ldots . . . . . . . . . . . . . . . .66$

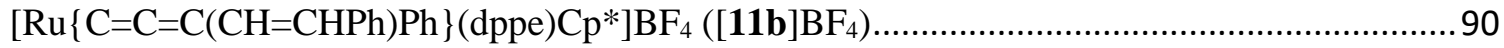

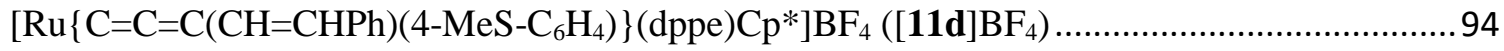

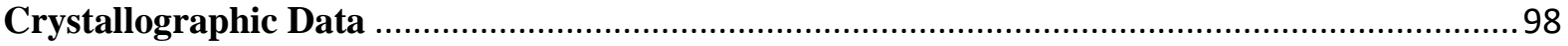

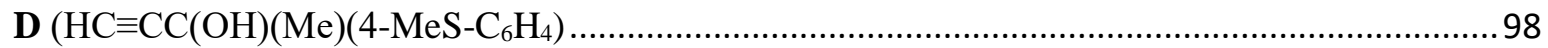




\section{${ }^{13} \mathrm{C}\left\{{ }^{1} \mathrm{H}\right\},{ }^{1} \mathrm{H}$ NMR and MS Spectra}

Propargylic Alcohols<smiles>C#CC(C)(O)c1ccccc1</smiles>

$\mathrm{HC} \equiv \mathrm{CC}(\mathrm{OH})(\mathrm{Me}) \mathrm{Ph}(\mathbf{B})$

$$
\text { mrh-01-45 }
$$

mrh-01-45
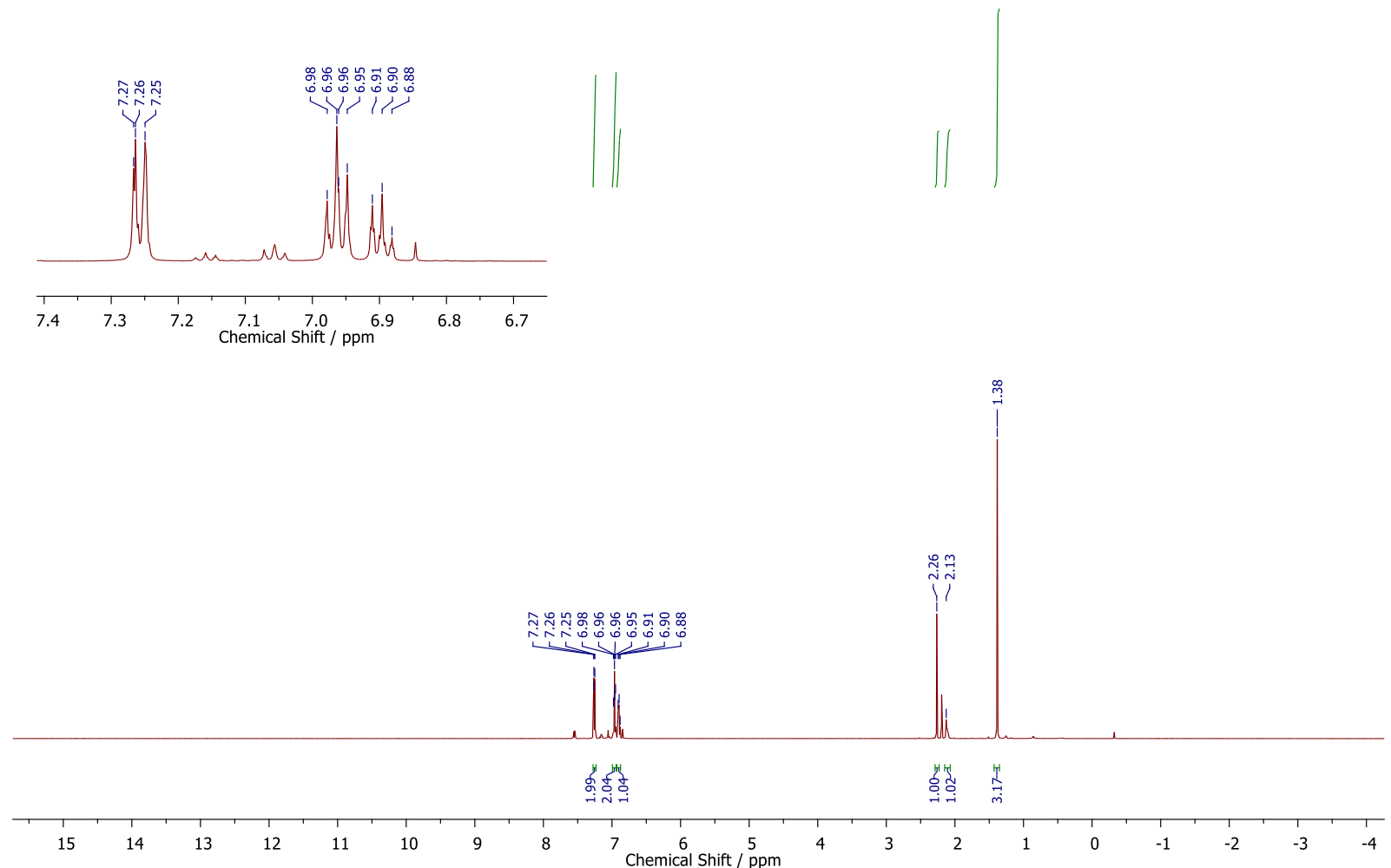

Figure S1. The ${ }^{1} \mathrm{H}$ NMR spectrum of $\mathbf{B}$. The inset shows an expansion of the aromatic region for clarity. 

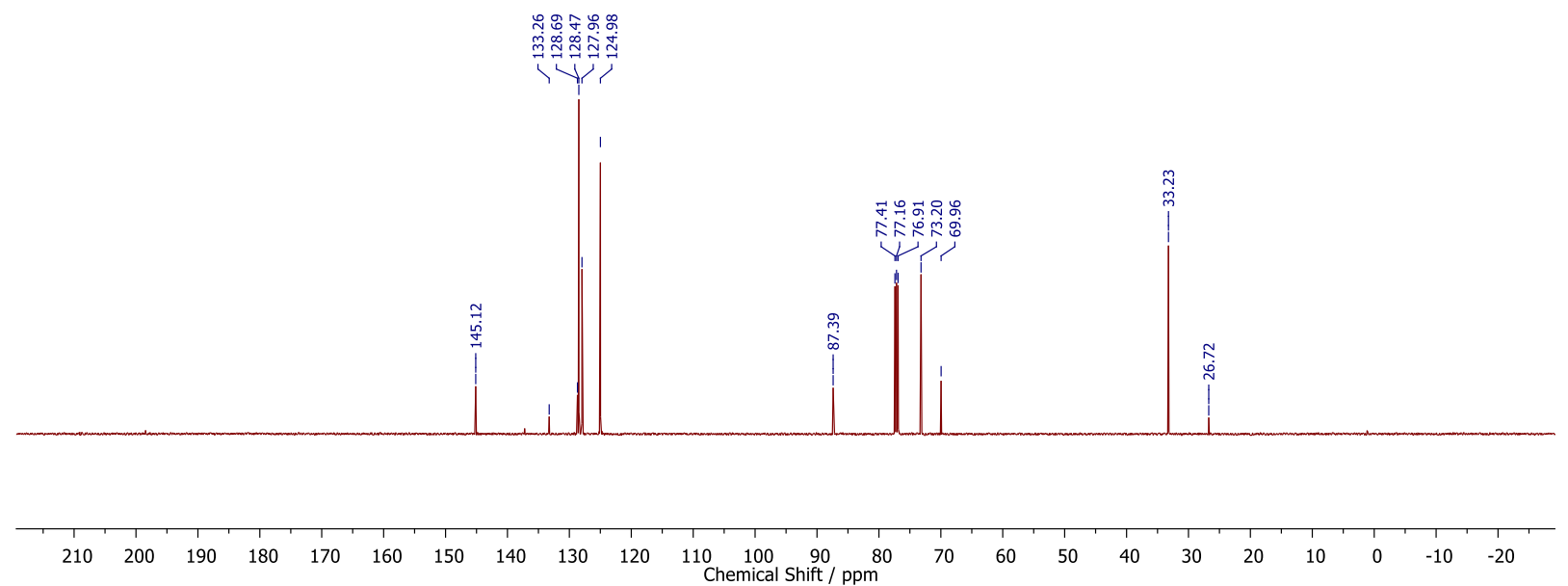

Figure S2. The ${ }^{13} \mathrm{C}\left\{{ }^{1} \mathrm{H}\right\}$ NMR spectrum of $\mathbf{B}$. The inset shows an expansion of the aromatic carbon region for clarity. 


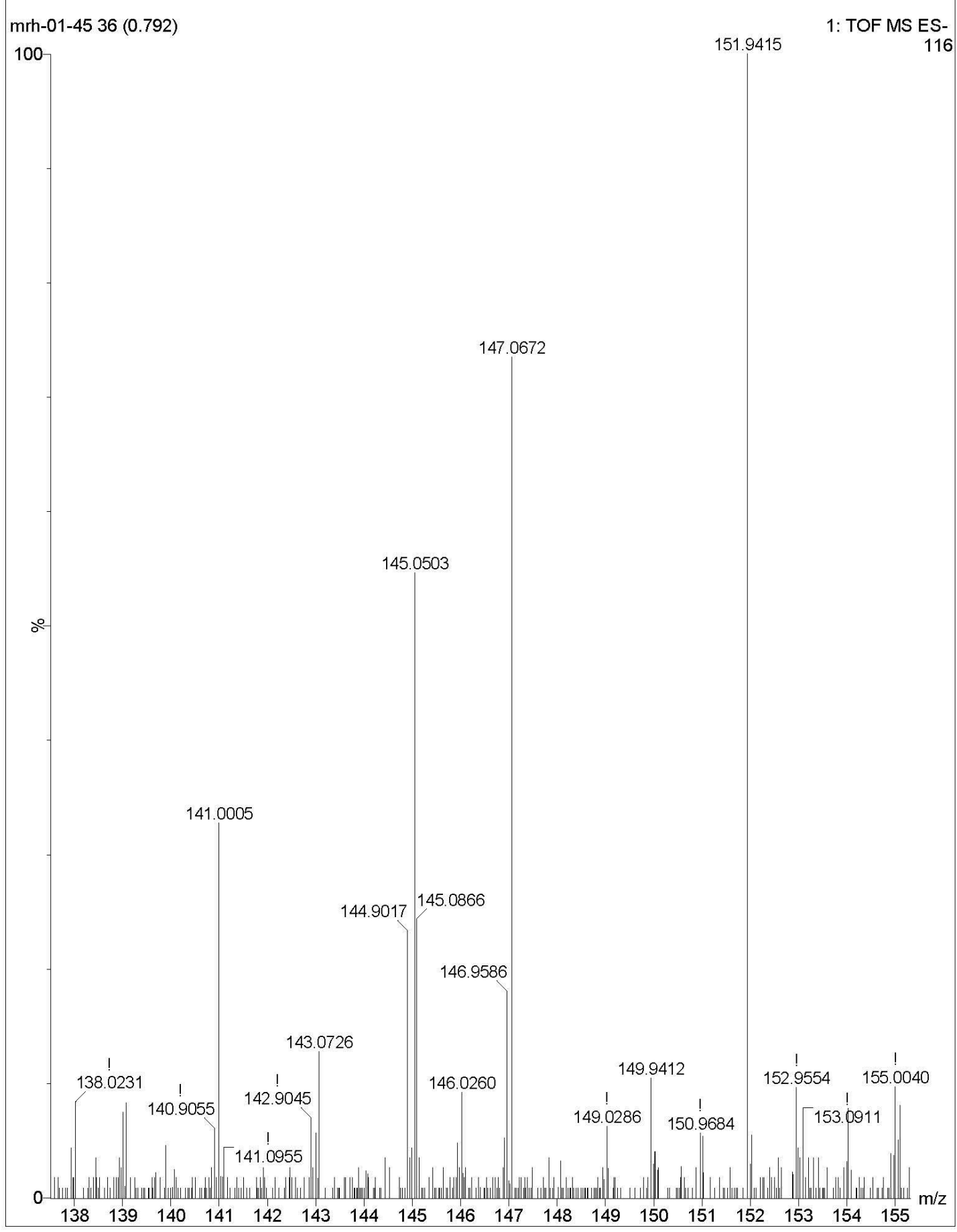

Figure S3. The ESI(+) mass spectrum of $\mathbf{B}$. 


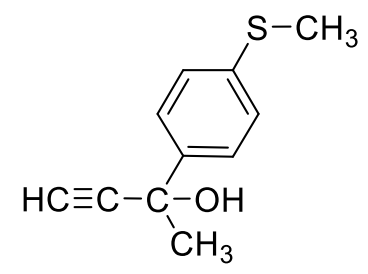

$\mathrm{HC} \equiv \mathrm{CC}(\mathrm{OH})(\mathrm{Me})\left(4-\mathrm{MeS}-\mathrm{C}_{6} \mathrm{H}_{4}\right)(\mathbf{D})$

mrh-01-77 column f2

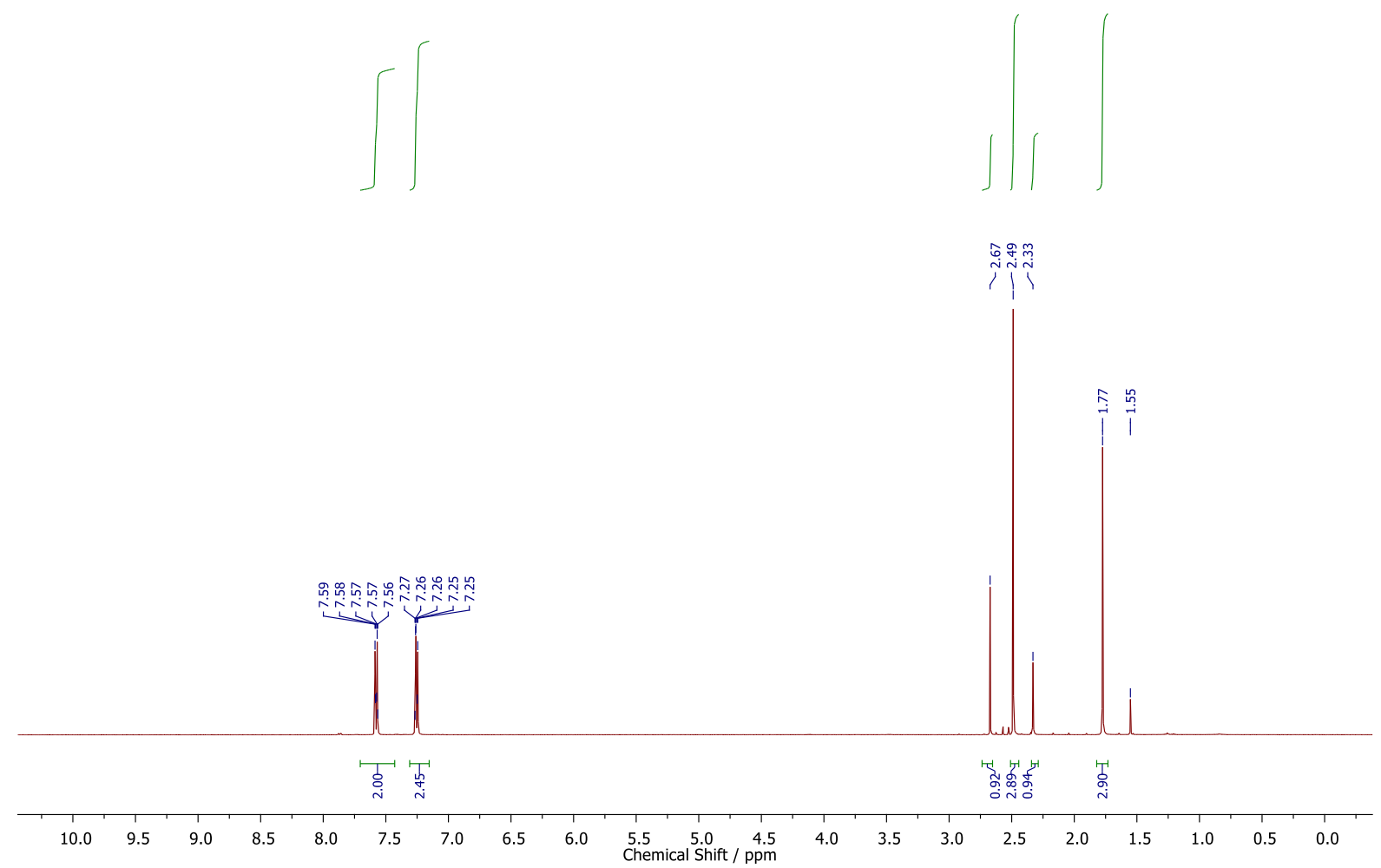

Figure S4. The ${ }^{1} \mathrm{H}$ NMR spectrum of $\mathbf{D}$. 


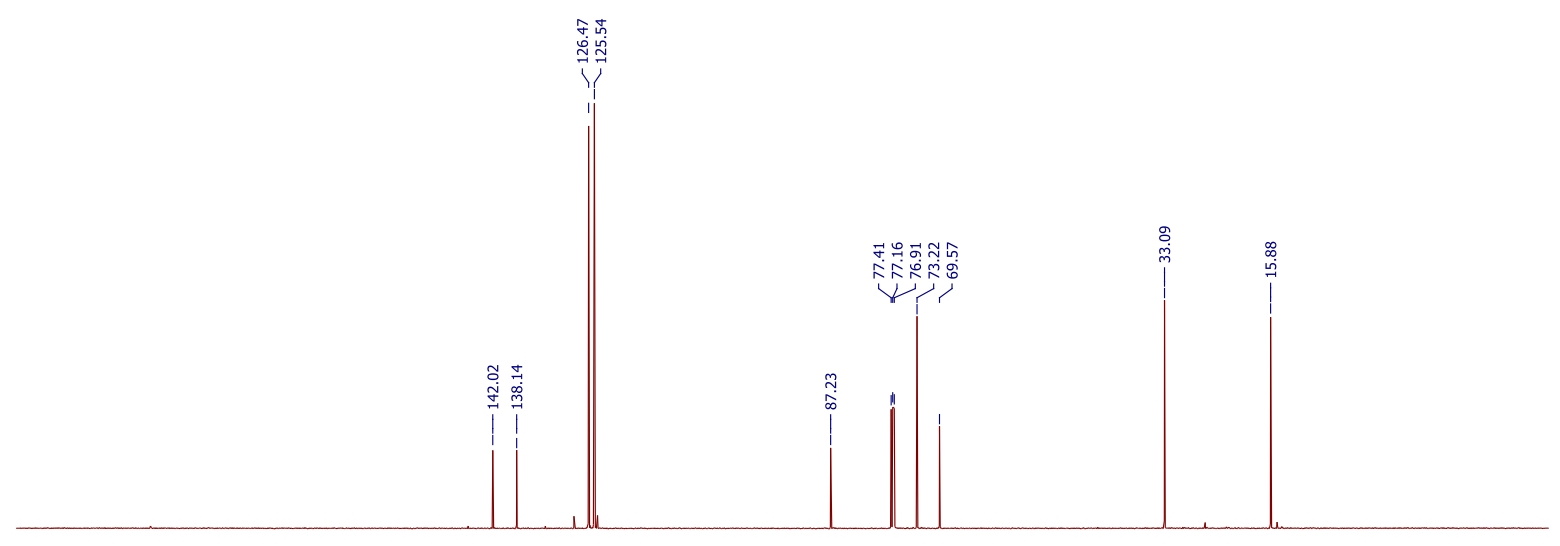

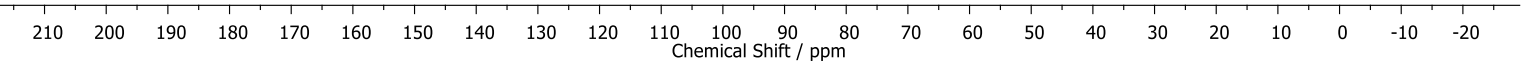

Figure S5. The ${ }^{13} \mathrm{C}\left\{{ }^{1} \mathrm{H}\right\}$ NMR spectrum of $\mathbf{D}$. 


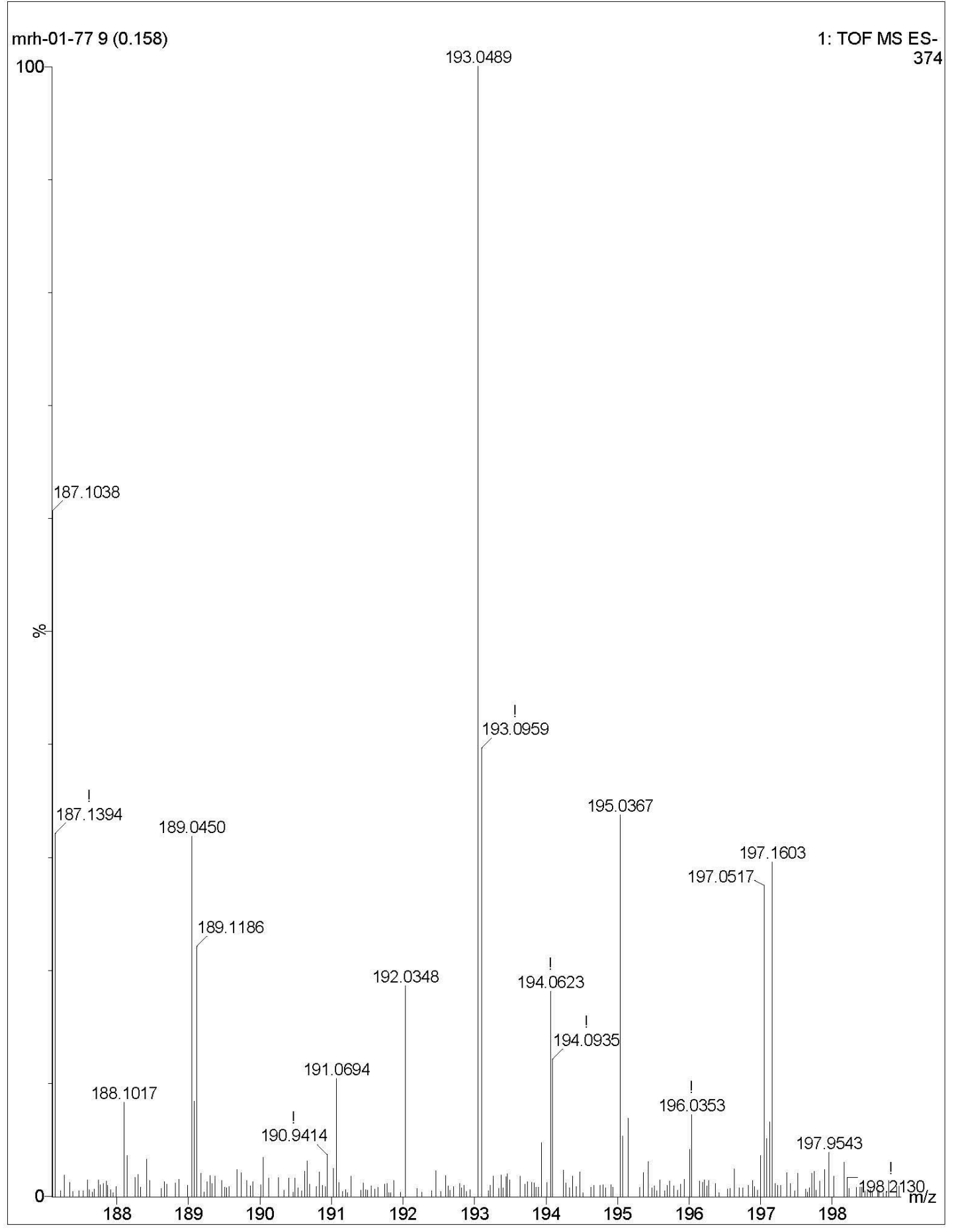

Figure S6. The ESI(+) mass spectrum of $\mathbf{D}$. 


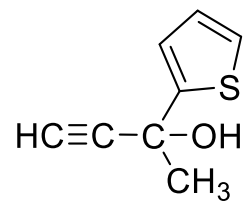

$\mathrm{HC} \equiv \mathrm{CC}(\mathrm{OH})(\mathrm{Me})\left(2-{ }^{c} \mathrm{C}_{4} \mathrm{H}_{3} \mathrm{~S}\right)(\mathbf{E})$

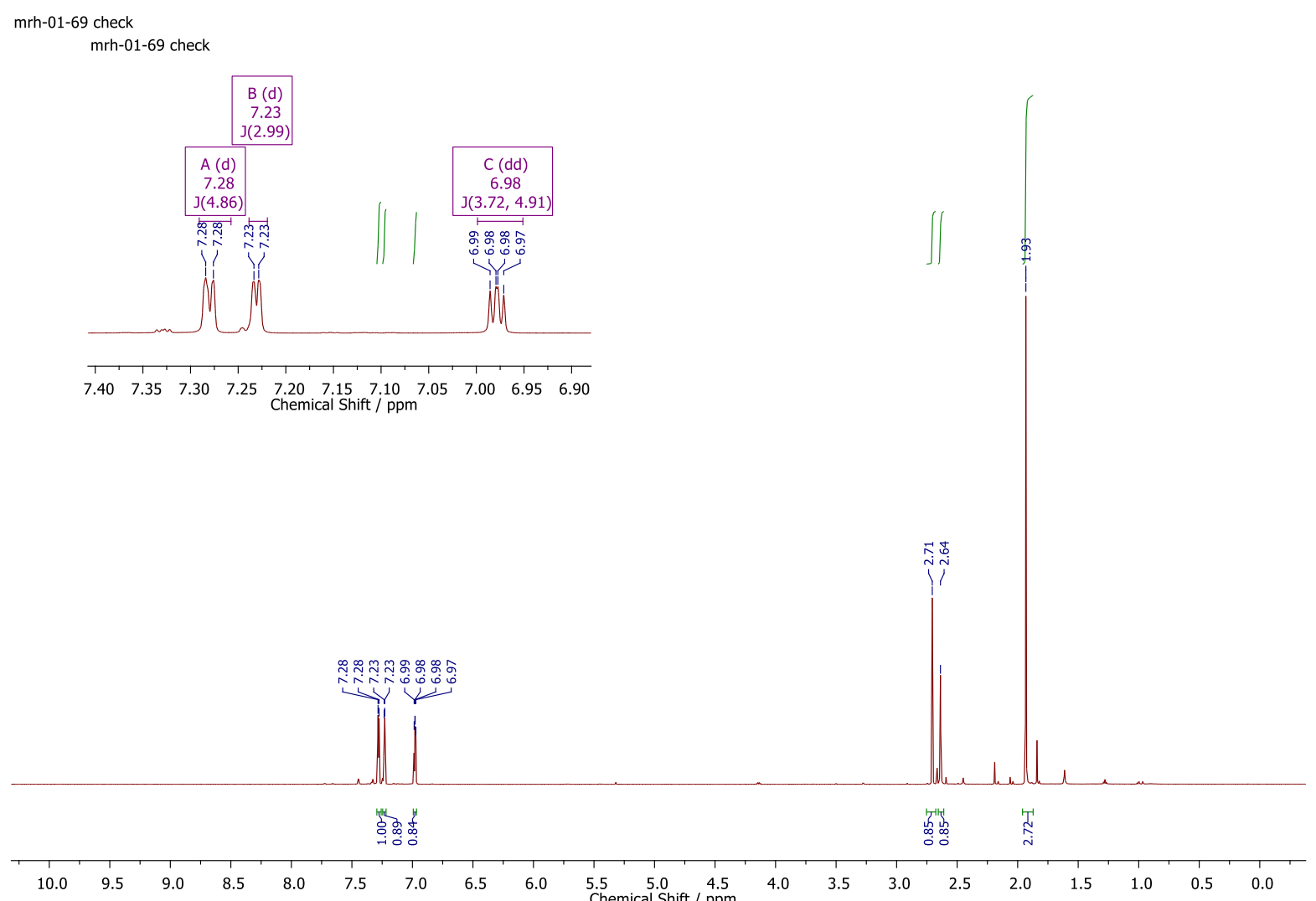

Figure S7. The ${ }^{1} \mathrm{H}$ NMR spectrum of $\mathbf{E}$. The inset shows an expansion of the aromatic region for clarity. 


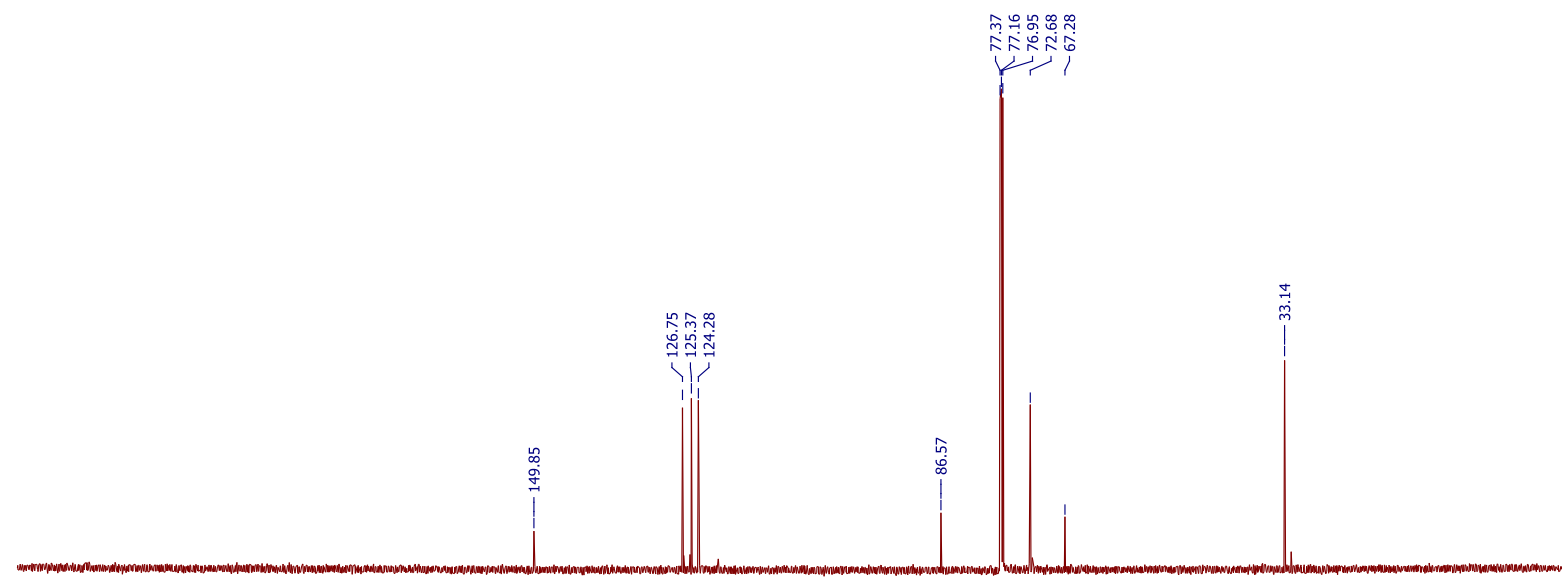

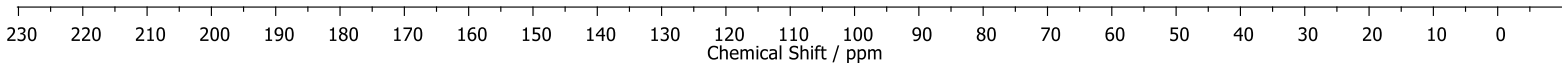

Figure S8. The ${ }^{13} \mathrm{C}\left\{{ }^{1} \mathrm{H}\right\}$ NMR spectrum of $\mathbf{E}$. 


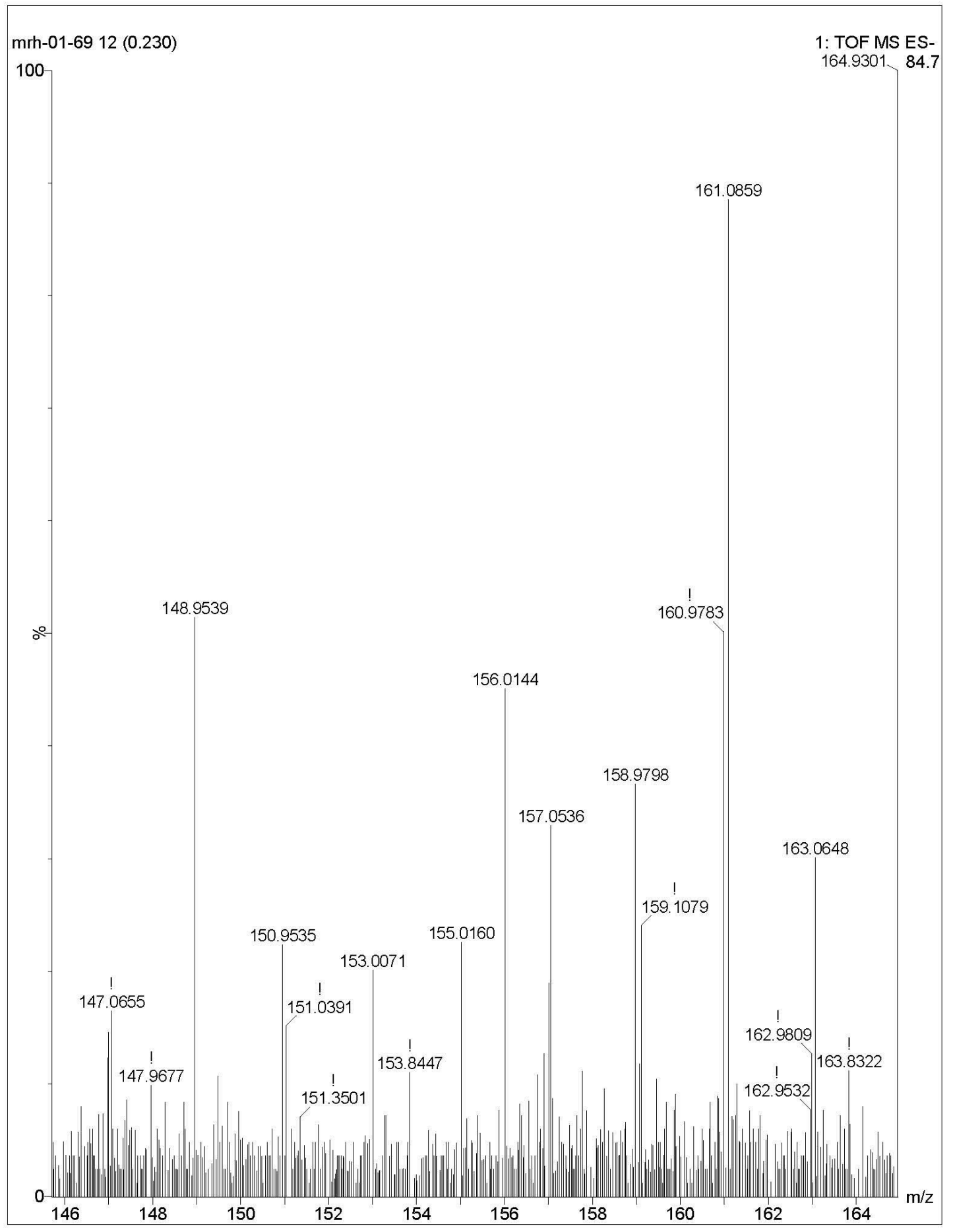

Figure S9. The ESI(+) mass spectrum of $\mathbf{E}$. 


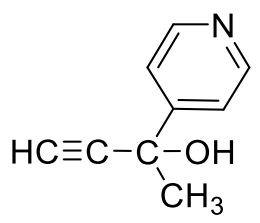

$\mathrm{HC} \equiv \mathrm{CC}(\mathrm{OH})(\mathrm{Me})\left(4-{ }^{c} \mathrm{C}_{5} \mathrm{H}_{4} \mathrm{~N}\right)(\mathbf{F})$

mrh-02-33-ii

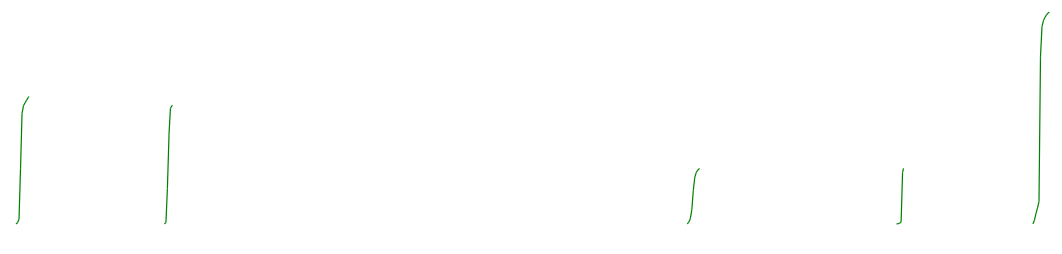

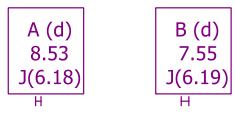

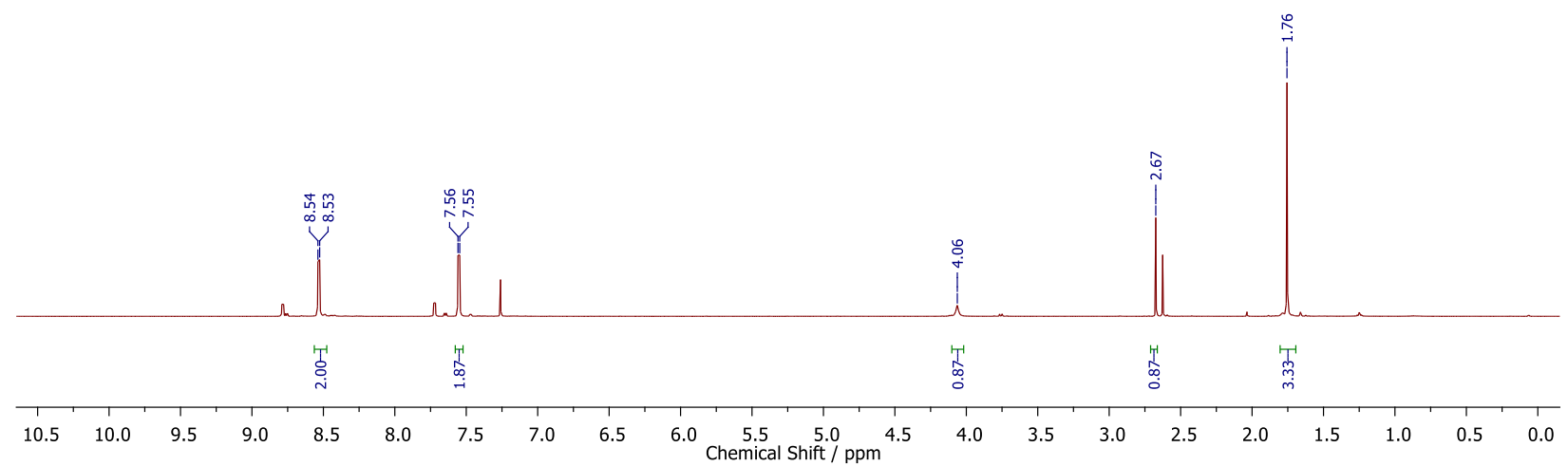

Figure S10. The ${ }^{1} \mathrm{H}$ NMR spectrum of $\mathbf{F}$. 
mrh-02-33-ii
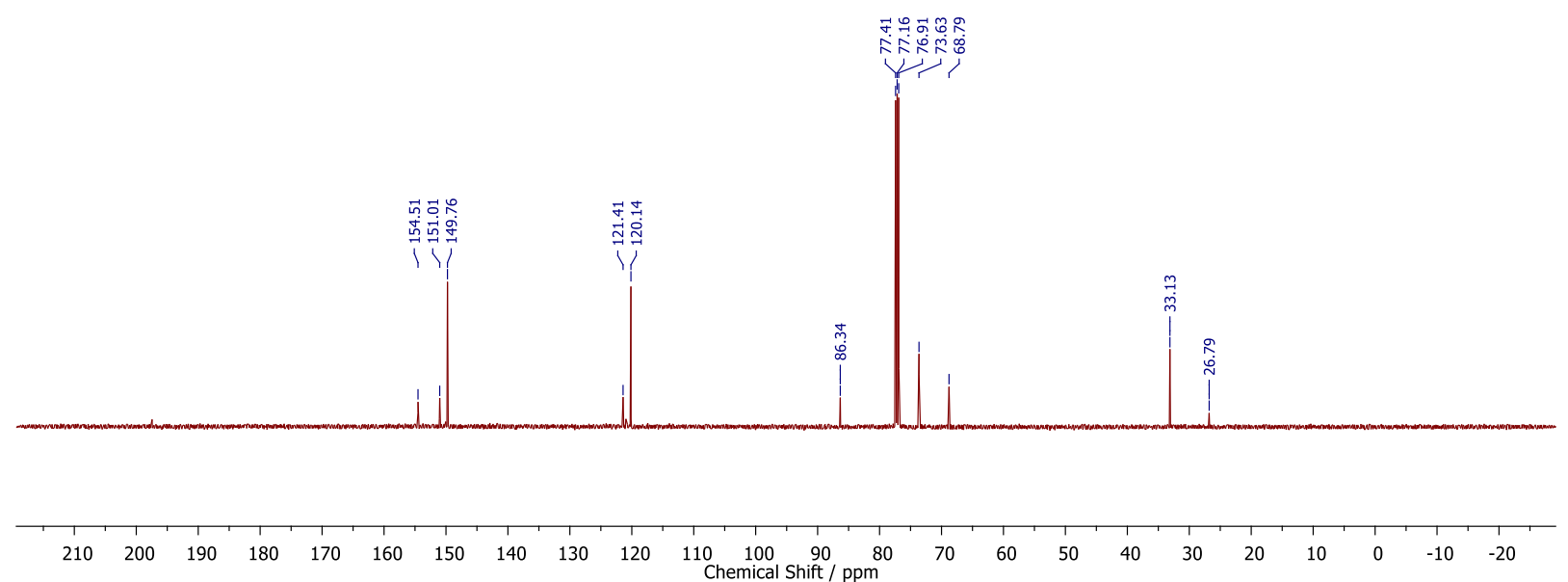

Figure S11. The ${ }^{13} \mathrm{C}\left\{{ }^{1} \mathrm{H}\right\} \mathrm{NMR}$ spectrum of $\mathbf{F}$. 


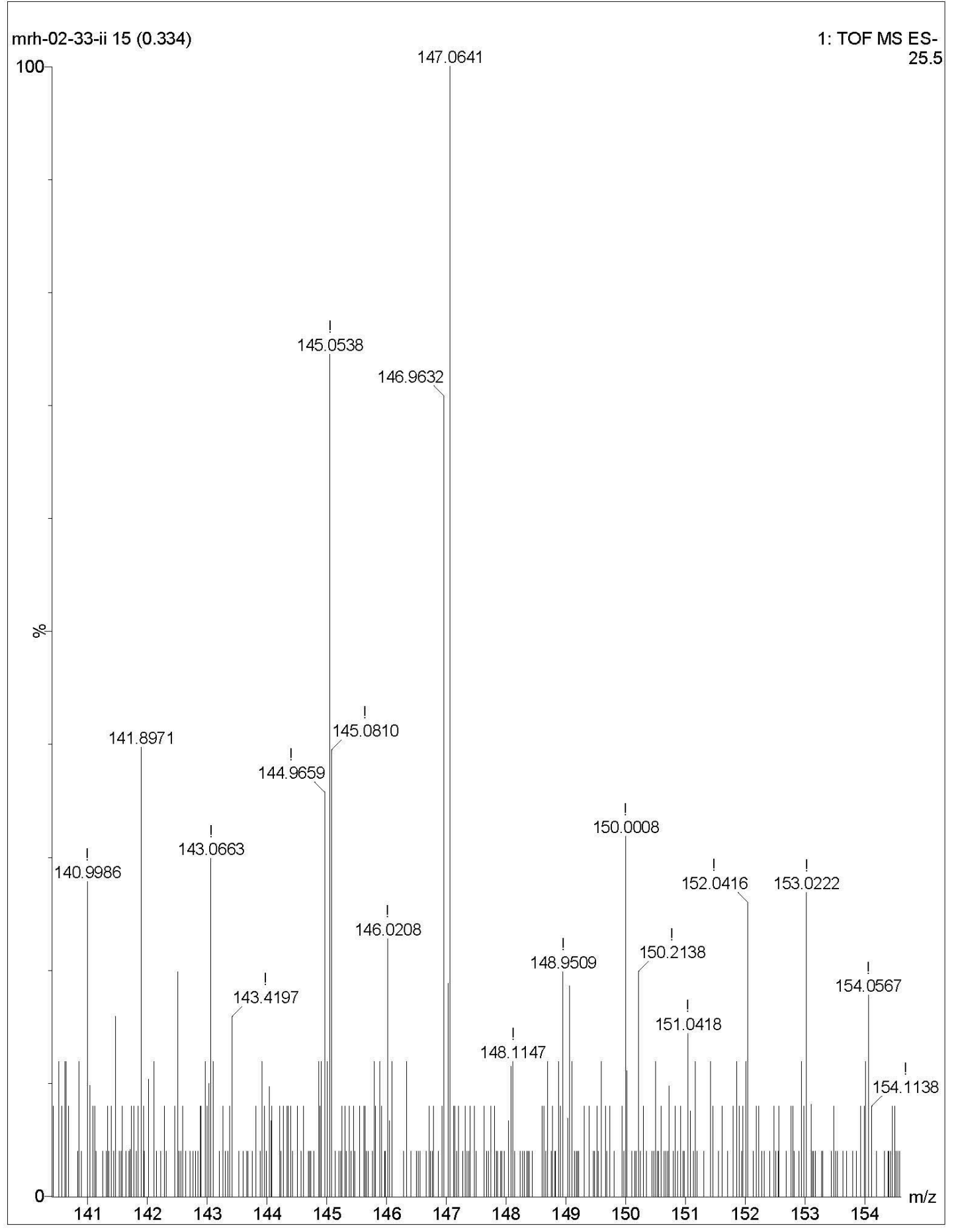

Figure S12. The ESI(+) mass spectrum of F. 
Methylallenylidenes

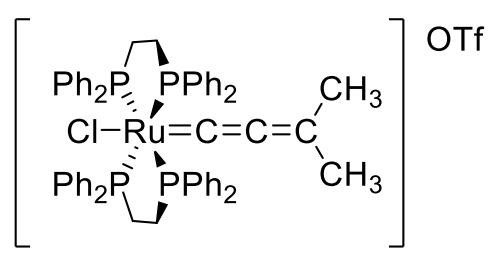

trans $-\left[\mathrm{Ru}\left(\mathrm{C}=\mathrm{C}=\mathrm{CMe}_{2}\right) \mathrm{Cl}(\mathrm{dppe})_{2}\right] \mathrm{OTf}([\mathbf{1 a}] \mathrm{OTF})$

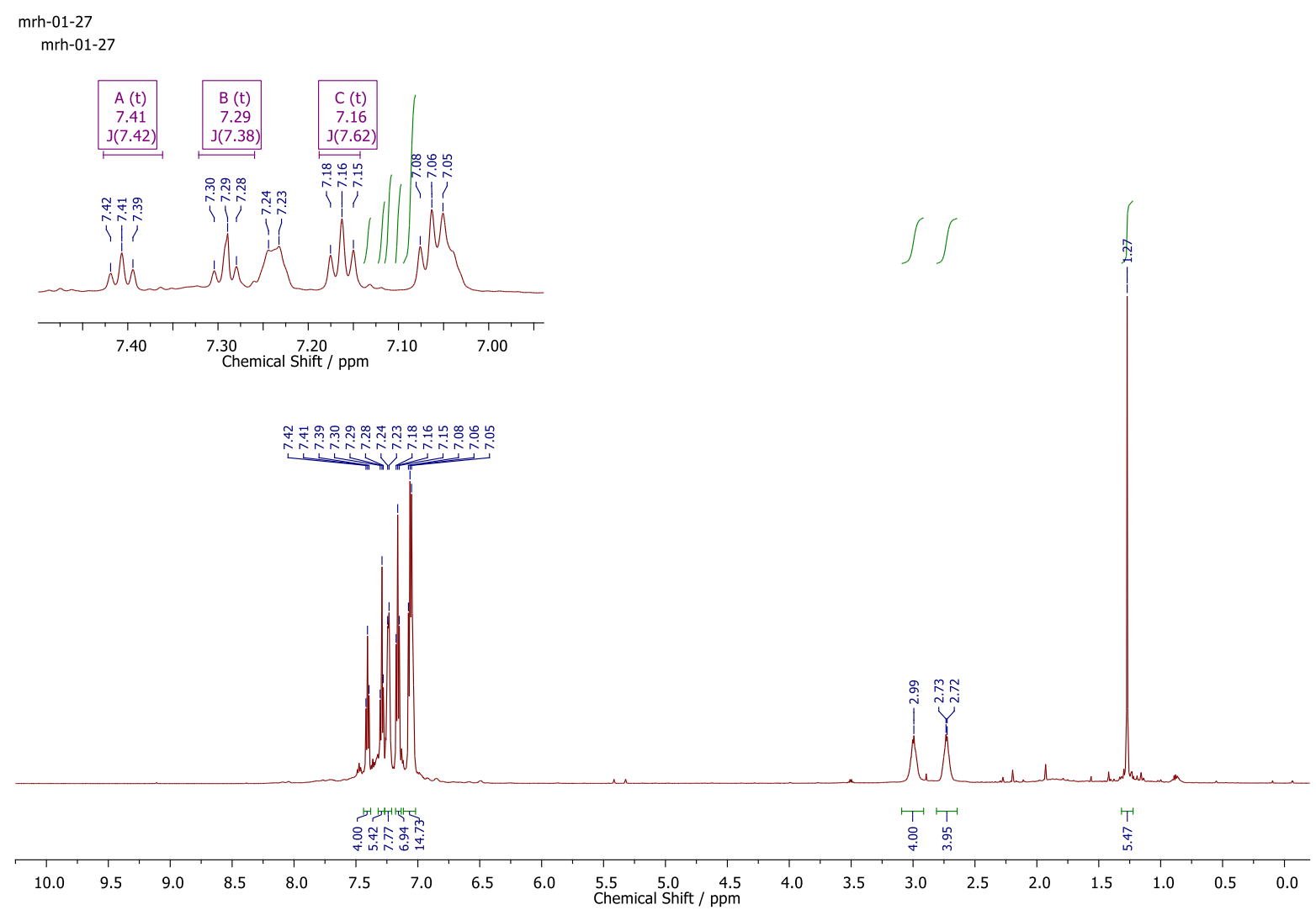

Figure S13. The ${ }^{1} \mathrm{H}$ NMR spectrum of [1a]OTf. The inset shows an expansion of the aromatic region for clarity. 


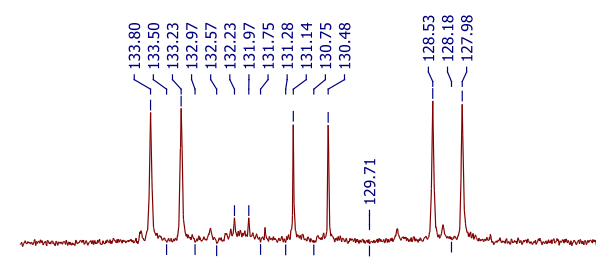

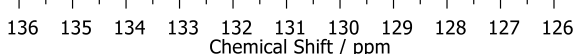

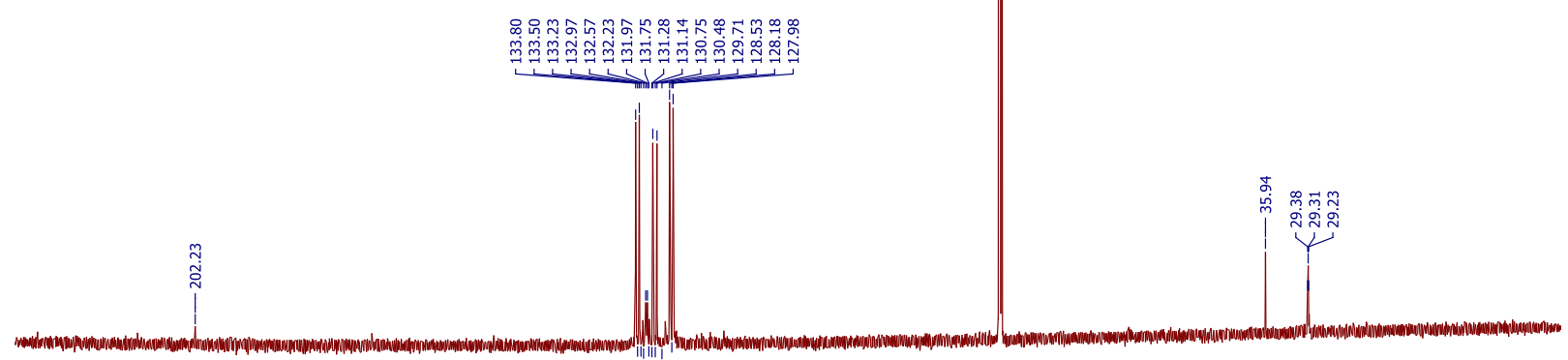

$\begin{array}{lllllllllllllllllllllllllllll}230 & 220 & 210 & 200 & 190 & 180 & 170 & 160 & 150 & 140 & 130 & 120 & 110 & 100 & 90 & 80 & 70 & 60 & 50 & 40 & 30 & 20 & 10 & 0\end{array}$

Figure S14. The ${ }^{13} \mathrm{C}\left\{{ }^{1} \mathrm{H}\right\}$ NMR spectrum of [1a]OTf. The inset shows an expansion of the aromatic carbon region for clarity. 


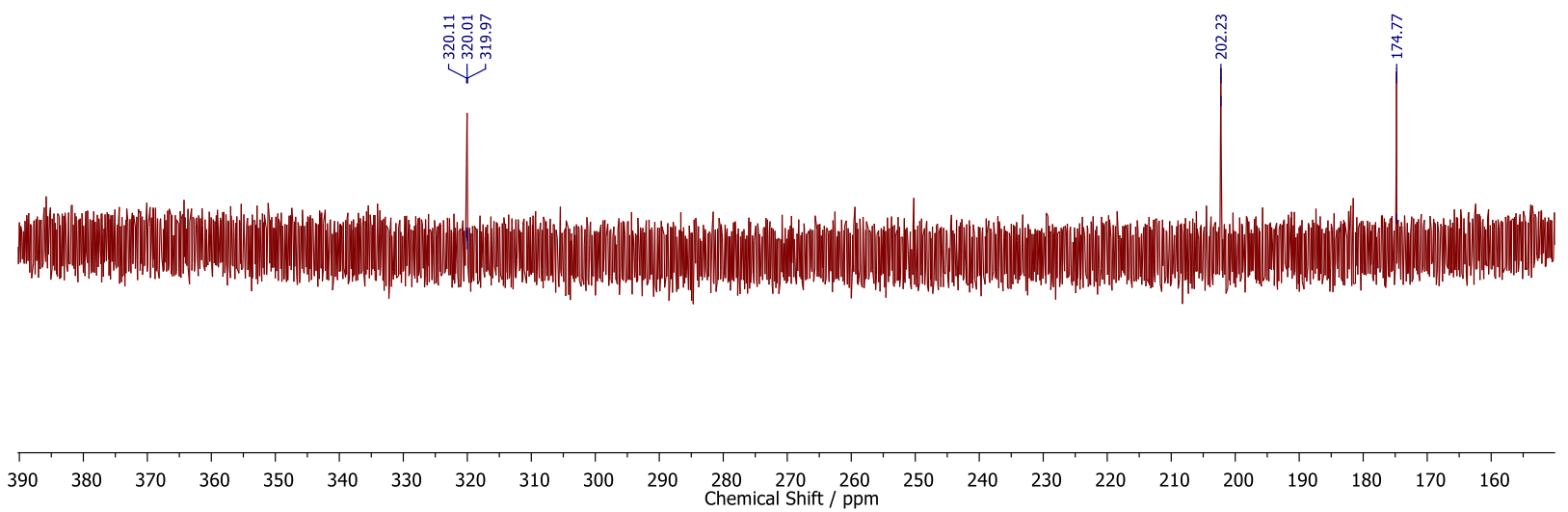

Figure S15. An expansion of the ${ }^{13} \mathrm{C}\left\{{ }^{1} \mathrm{H}\right\}$ NMR spectrum of [1a]OTf, showing the allenylidene $C(\alpha), C(\beta)$ and $C(\gamma)$ resonances. 


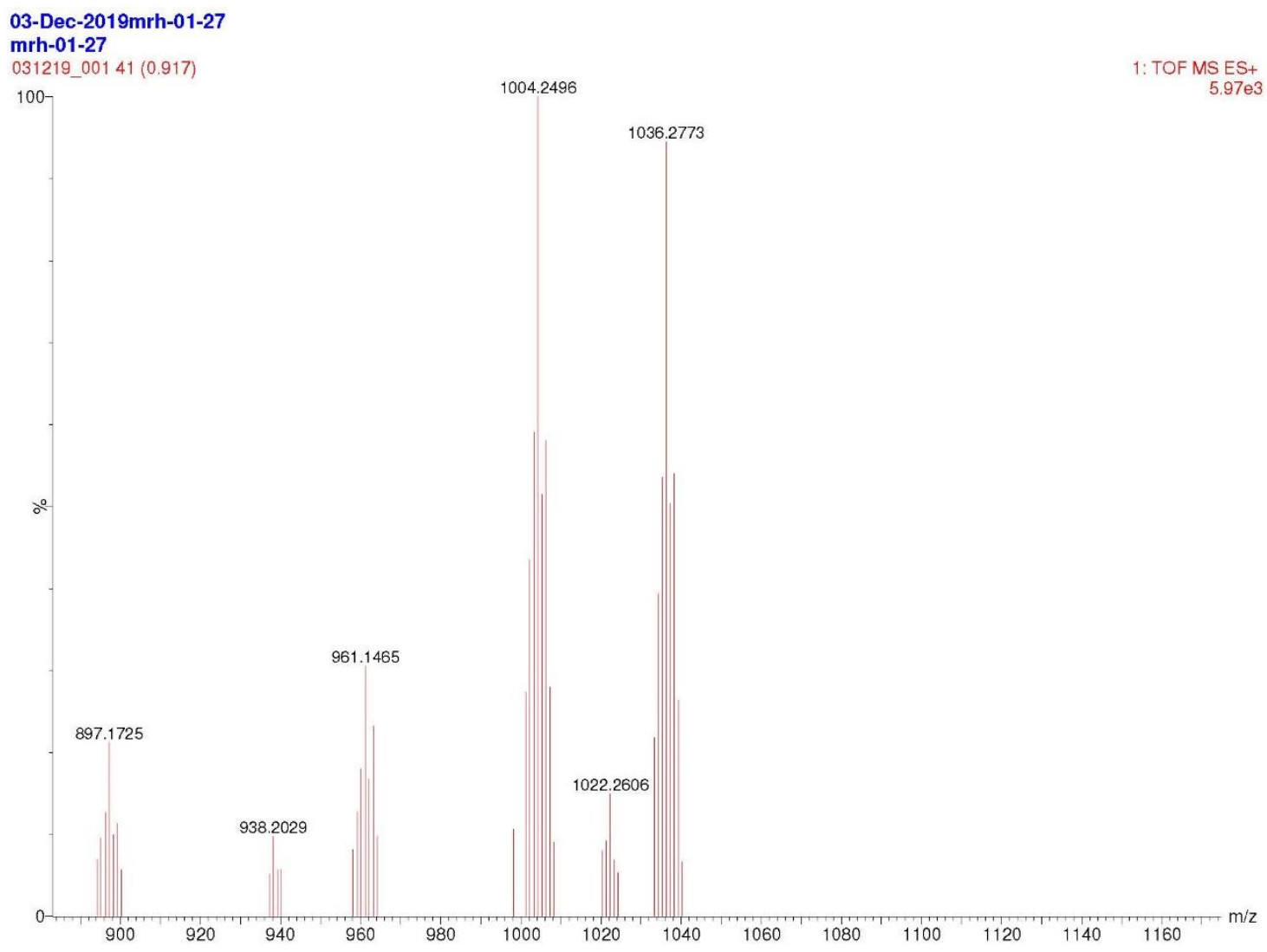

Figure S16. The ESI(+) mass spectrum of [1a]OTf. 


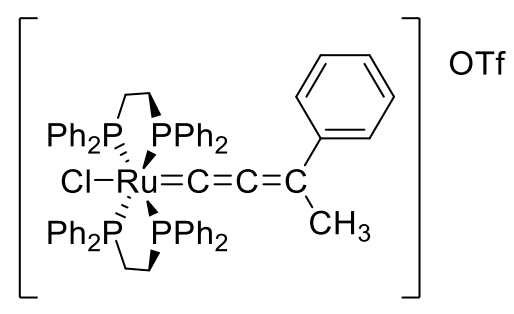

trans $-\left[\mathrm{Ru}\{\mathrm{C}=\mathrm{C}=\mathrm{C}(\mathrm{Me}) \mathrm{Ph}\} \mathrm{Cl}(\text { dppe })_{2}\right] \mathrm{OTf}([\mathbf{1 b}] \mathrm{OTF})$

mrh-01-54

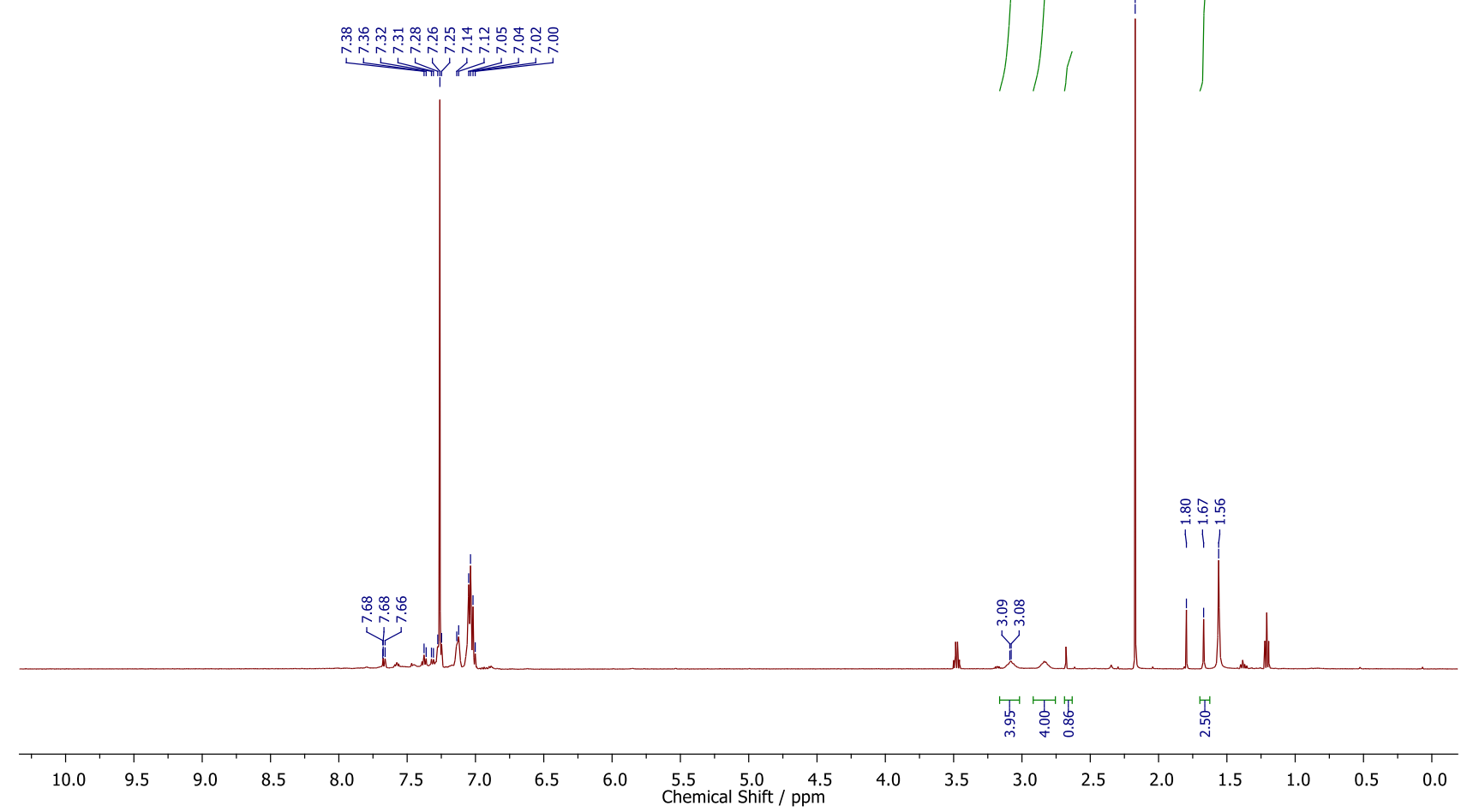

Figure 17. The ${ }^{1} \mathrm{H}$ NMR spectrum of [1b]OTf. 

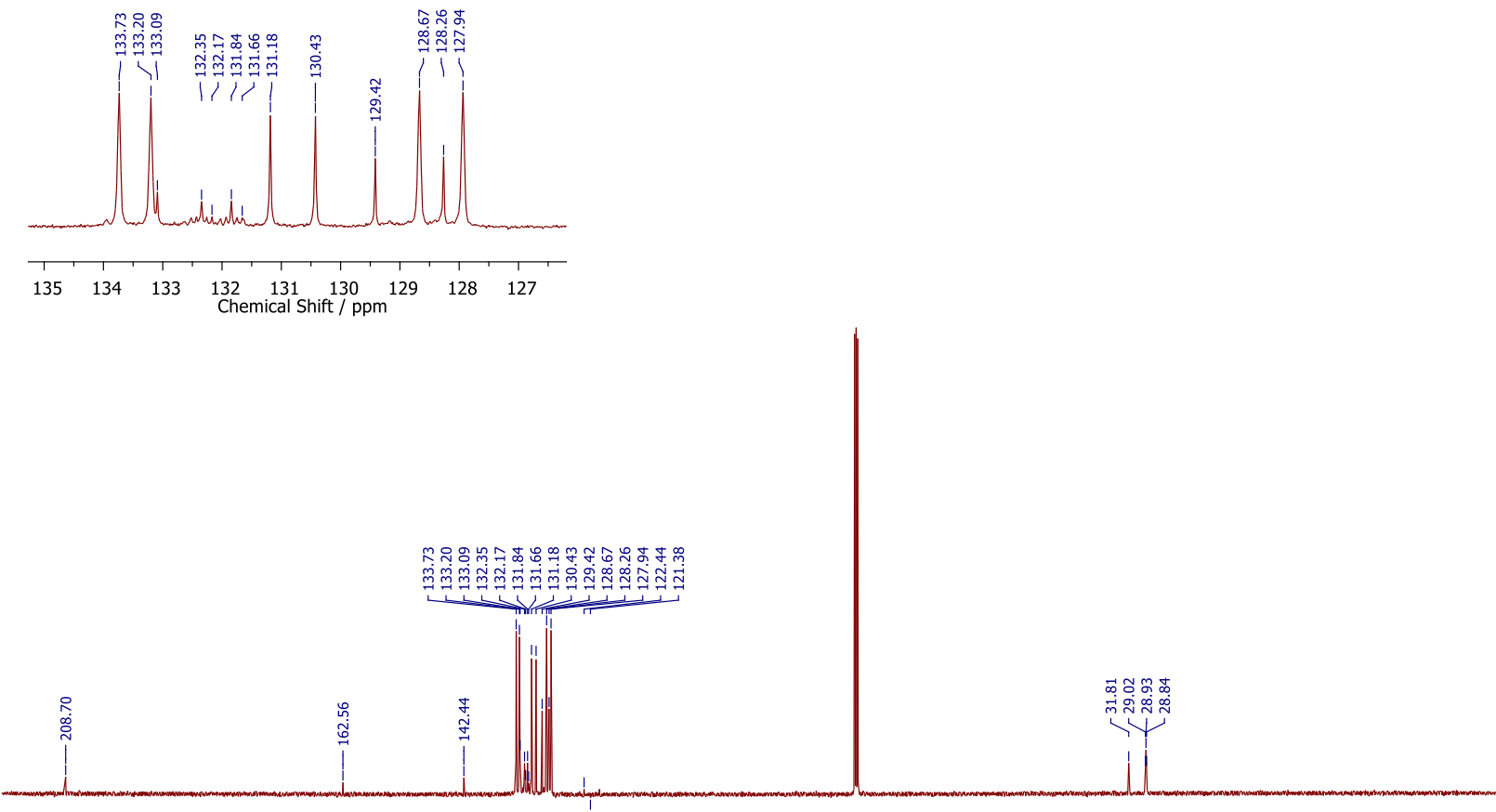

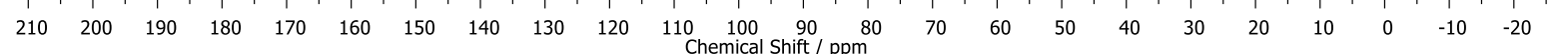

Figure S18. The ${ }^{13} \mathrm{C}\left\{{ }^{1} \mathrm{H}\right\}$ NMR spectrum of [1b]OTf. The inset shows an expansion of the aromatic carbon region for clarity. 


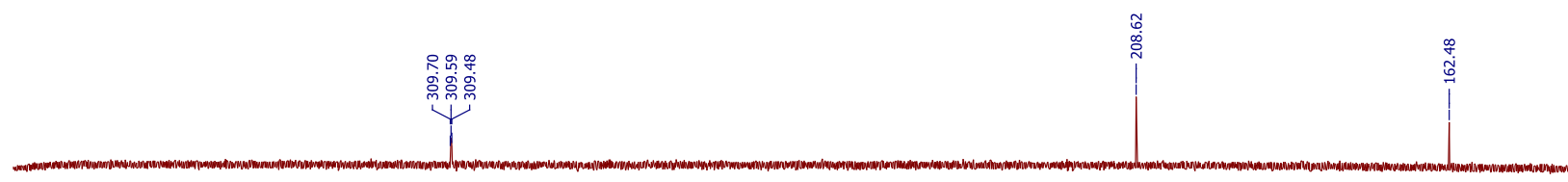

$\begin{array}{lllllllllllllllllllllllll}370 & 360 & 350 & 340 & 330 & 320 & 310 & 300 & 290 & 280 & 270 & 260 & 250 & 240 & 230 & 220 & 210 & 200 & 190 & 180 & 170 & 160 & 150\end{array}$

Figure S19. An expansion of the ${ }^{13} \mathrm{C}\left\{{ }^{1} \mathrm{H}\right\}$ NMR spectrum of [1b]OTf, showing the allenylidene $C(\alpha), C(\beta)$ and $C(\gamma)$ resonances. 


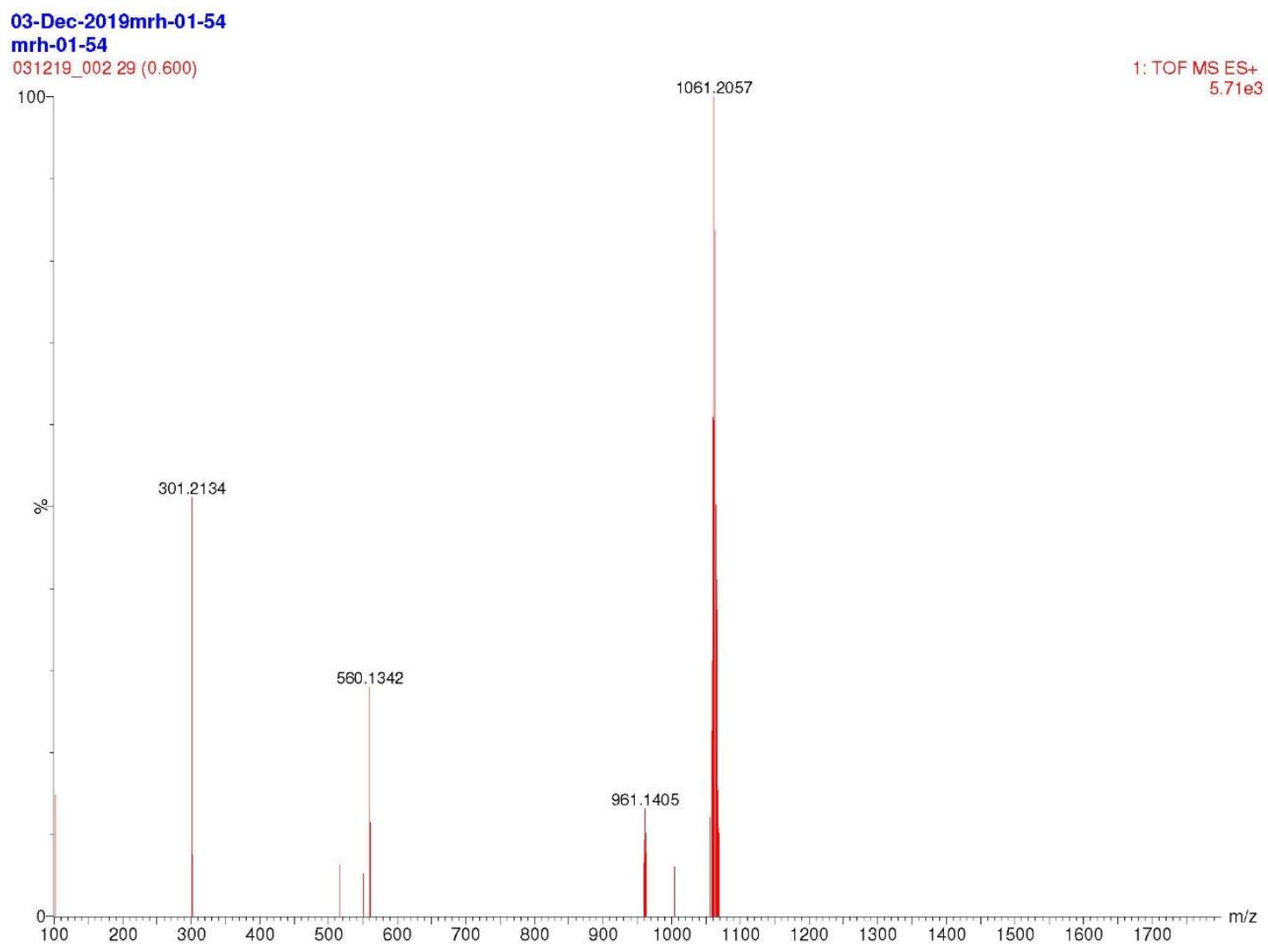

Figure S20. The ESI(+) mass spectrum of $[\mathbf{1 b}] \mathrm{OTf}$. 


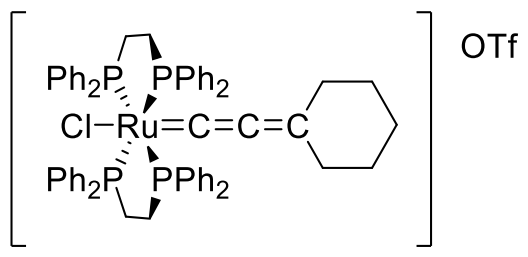

trans $-\left[\mathrm{Ru}\left\{\mathrm{C}=\mathrm{C}=\mathrm{C}\left({ }^{c} \mathrm{C}_{5} \mathrm{H}_{10}\right)\right\} \mathrm{Cl}(\mathrm{dppe})_{2}\right] \mathrm{OTf}([\mathbf{1}] \mathrm{OTF})$

Figure 21. The ${ }^{1} \mathrm{H}$ NMR spectrum of [1c]OTf.

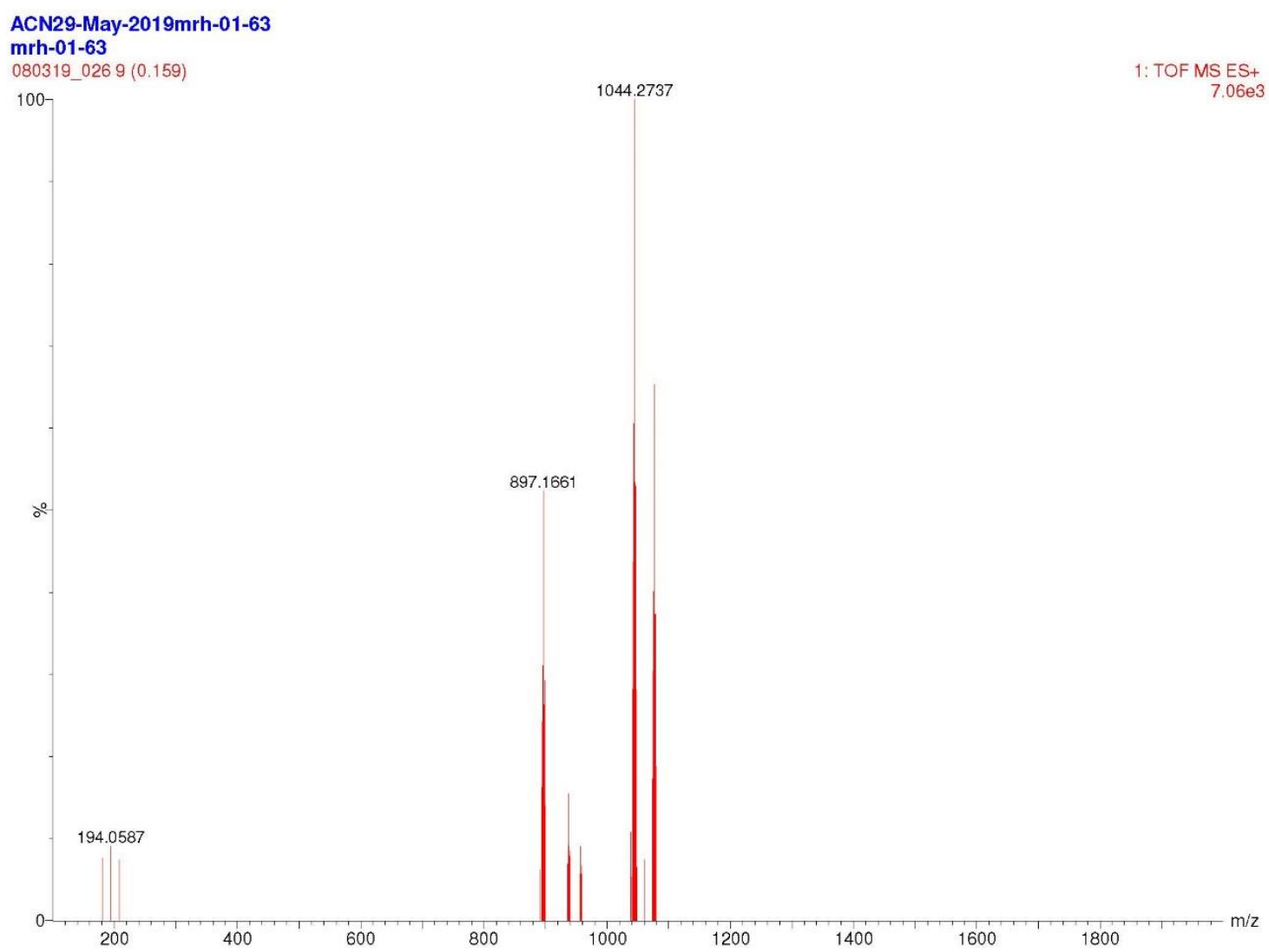

Figure S22. The ESI(+) mass spectrum of $[\mathbf{1 c}] \mathrm{OTf}$. 


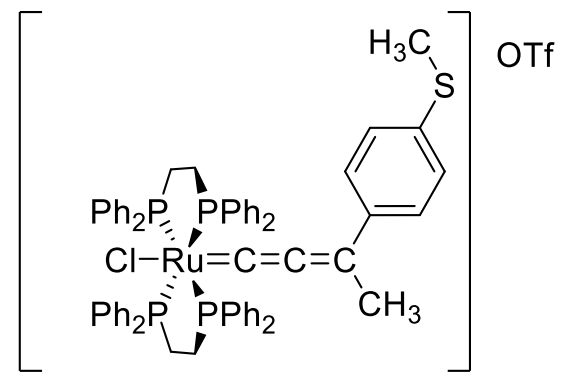

trans $-\left[\mathrm{Ru}\left\{\mathrm{C}=\mathrm{C}=\mathrm{C}(\mathrm{Me})\left(4-\mathrm{MeS}-\mathrm{C}_{6} \mathrm{H}_{4}\right)\right\} \mathrm{Cl}(\mathrm{dppe})_{2}\right] \mathrm{OTf}([\mathbf{1 d}] \mathrm{OTF})$
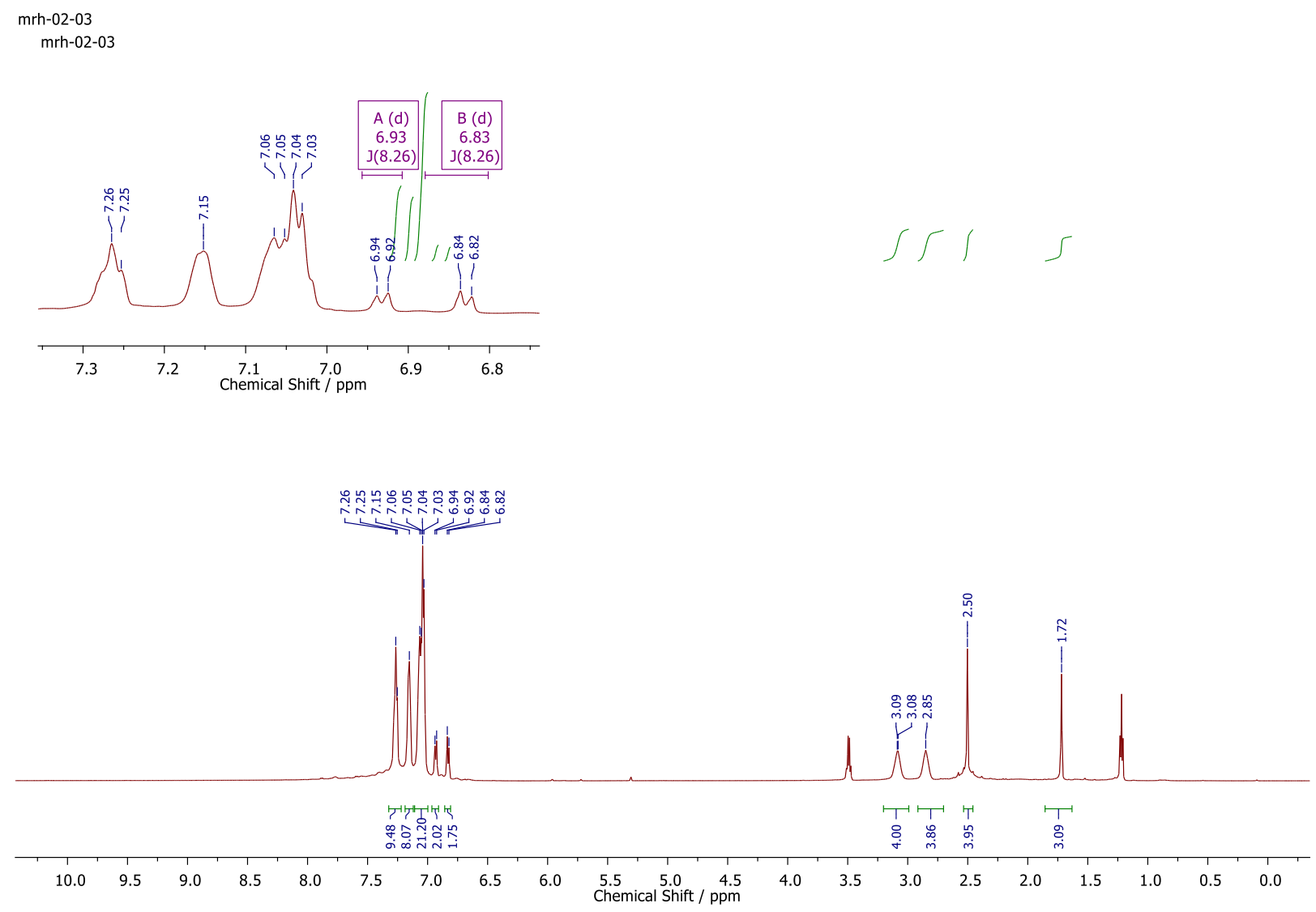

Figure S23. The ${ }^{1} \mathrm{H}$ NMR spectrum of $[\mathbf{1 d}] \mathrm{OTf}$. The inset shows an expansion of the aromatic region for clarity. 

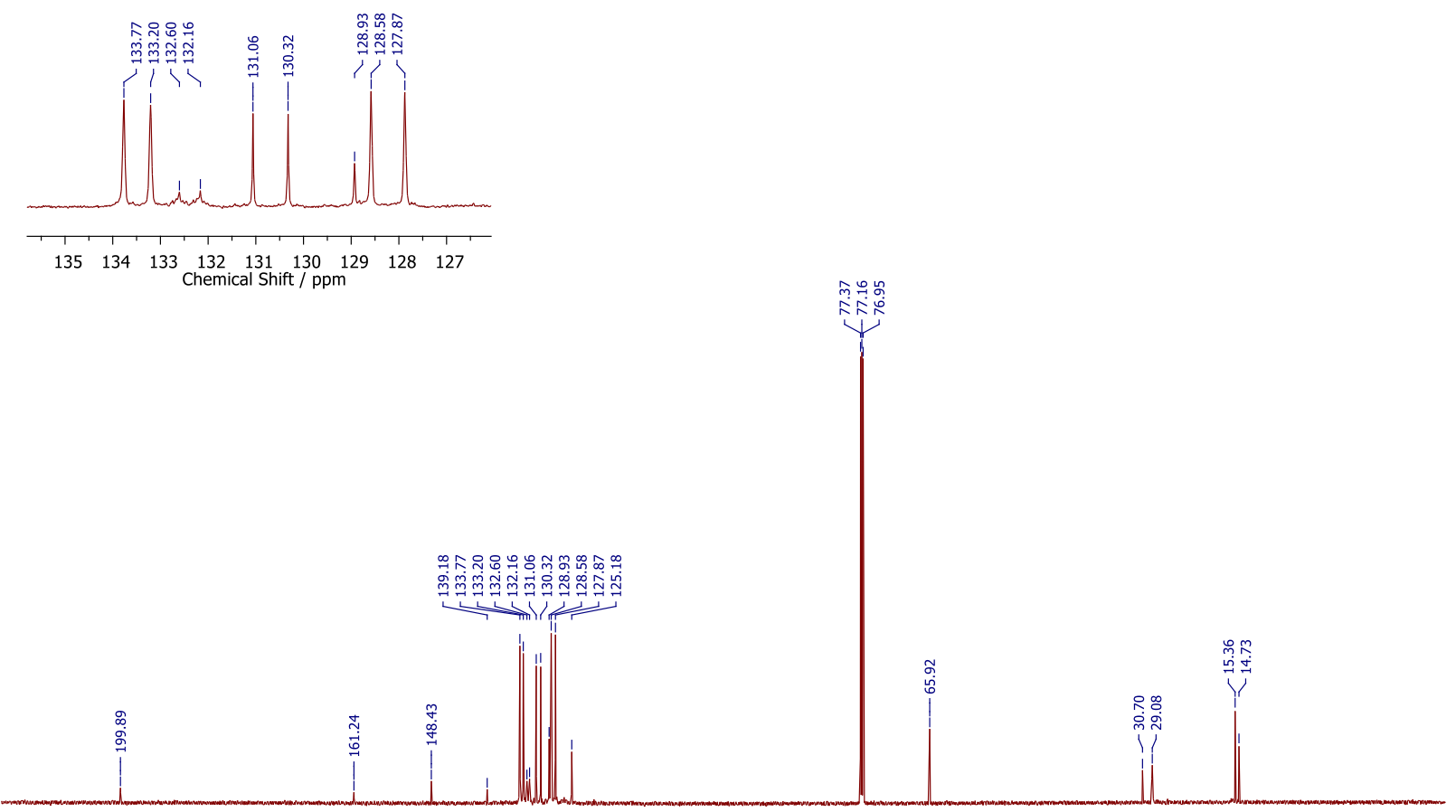

$\begin{array}{lllllllllllllllllllllll}210 & 200 & 190 & 180 & 170 & 160 & 150 & 140 & 130 & 120 & 110 & 100 & 90 & 80 & 70 & 60 & 50 & 40 & 30 & 20 & 10 & 0 & -10\end{array}$

Figure S24. The ${ }^{13} \mathrm{C}\left\{{ }^{1} \mathrm{H}\right\}$ NMR spectrum of [1d]OTf. The inset shows an expansion of the aromatic carbon region for clarity 


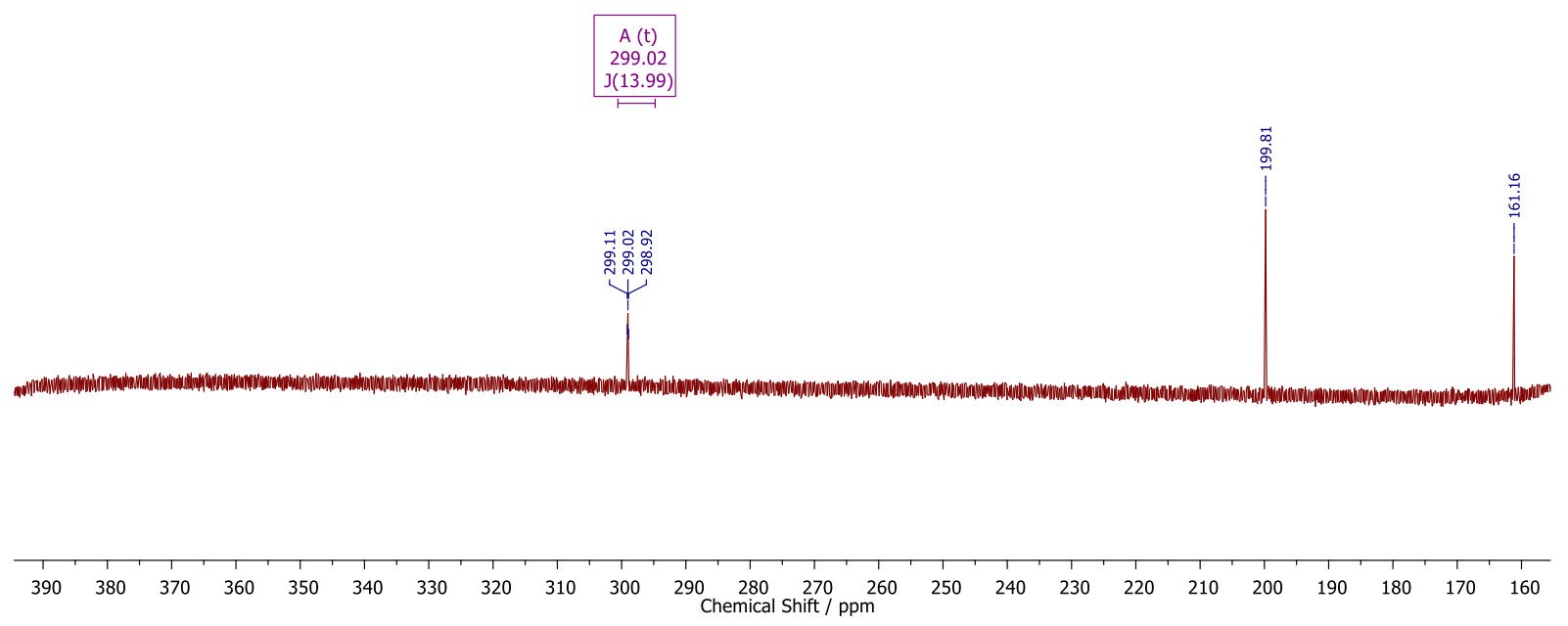

Figure S25. An expansion of the ${ }^{13} \mathrm{C}\left\{{ }^{1} \mathrm{H}\right\}$ NMR spectrum of [1d]OTf, showing the allenylidene $C(\alpha), C(\beta)$ and $C(\gamma)$ resonances. 


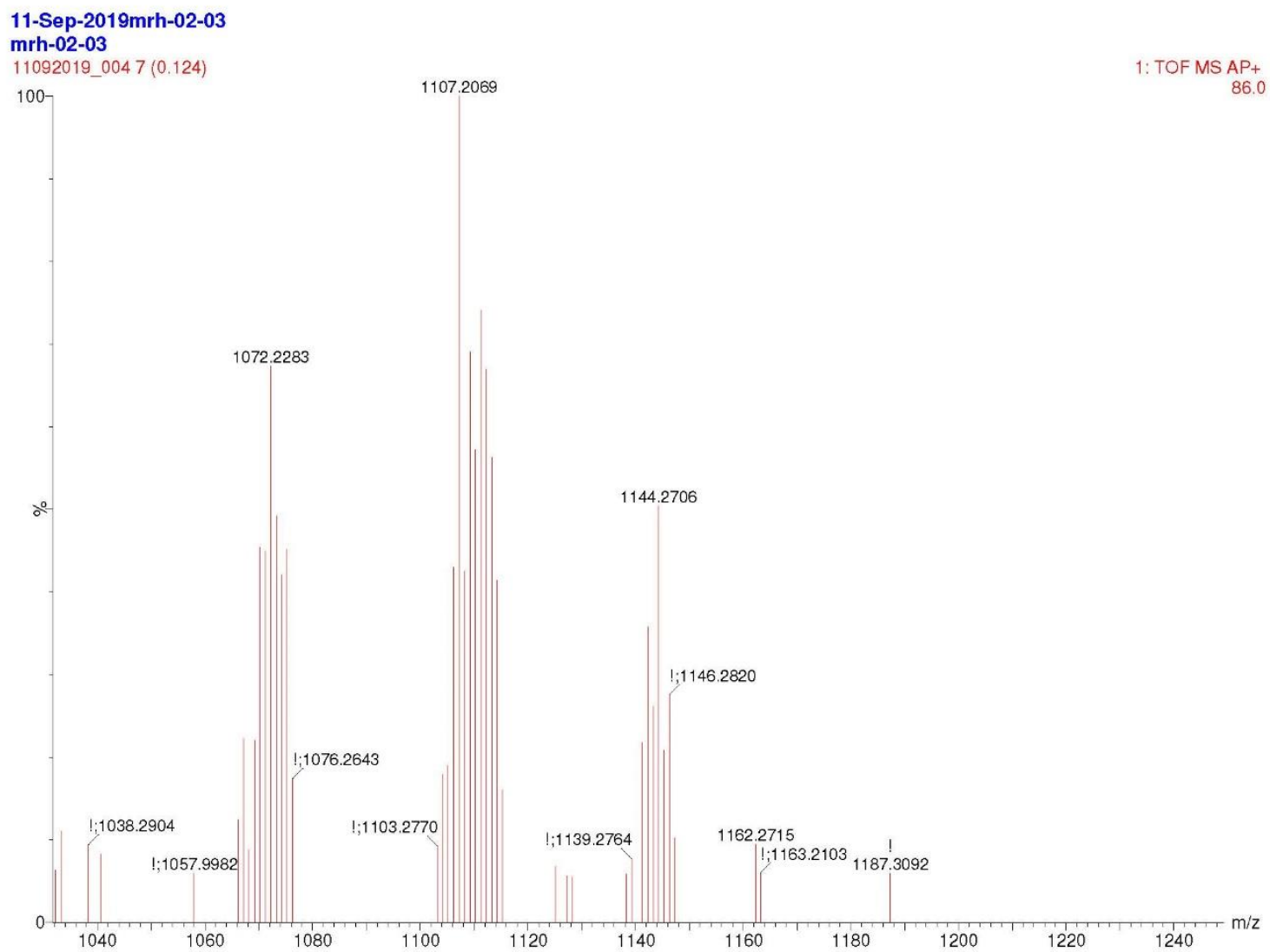

Figure S26. The APCI(+) mass spectrum of [1d]OTf. 


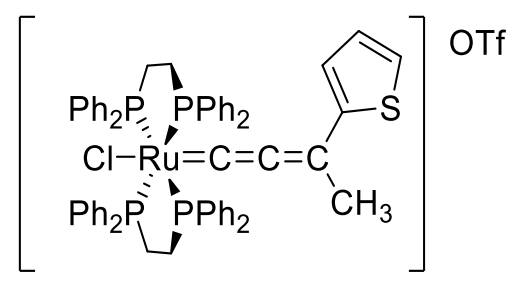

trans $-\left[\mathrm{Ru}\left\{\mathrm{C}=\mathrm{C}=\mathrm{C}(\mathrm{Me})\left(2-{ }^{c} \mathrm{C}_{4} \mathrm{H}_{3} \mathrm{~S}\right)\right\} \mathrm{Cl}(\mathrm{dppe})_{2}\right] \mathrm{OTf}([\mathbf{1 e}] \mathrm{OTF})$

mrh-02-08

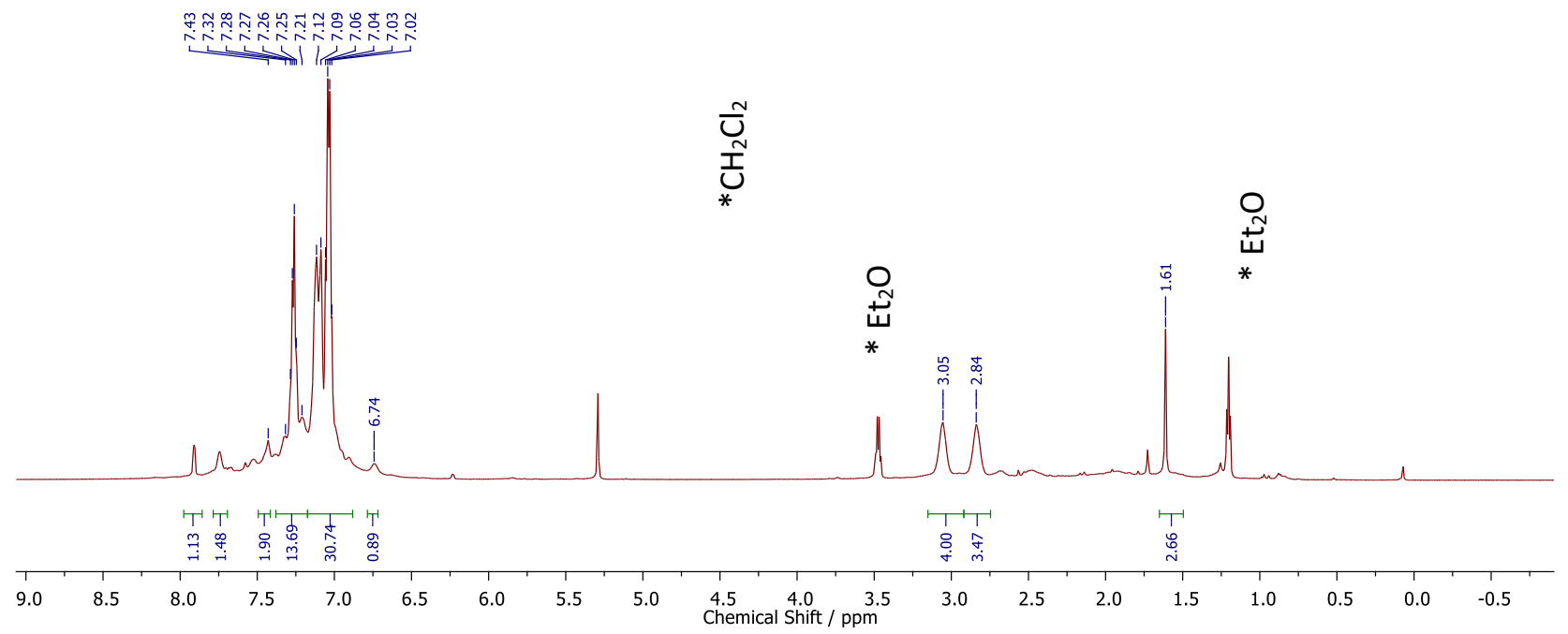

Figure S27. The ${ }^{1} \mathrm{H}$ NMR spectrum of [1e]OTf. 

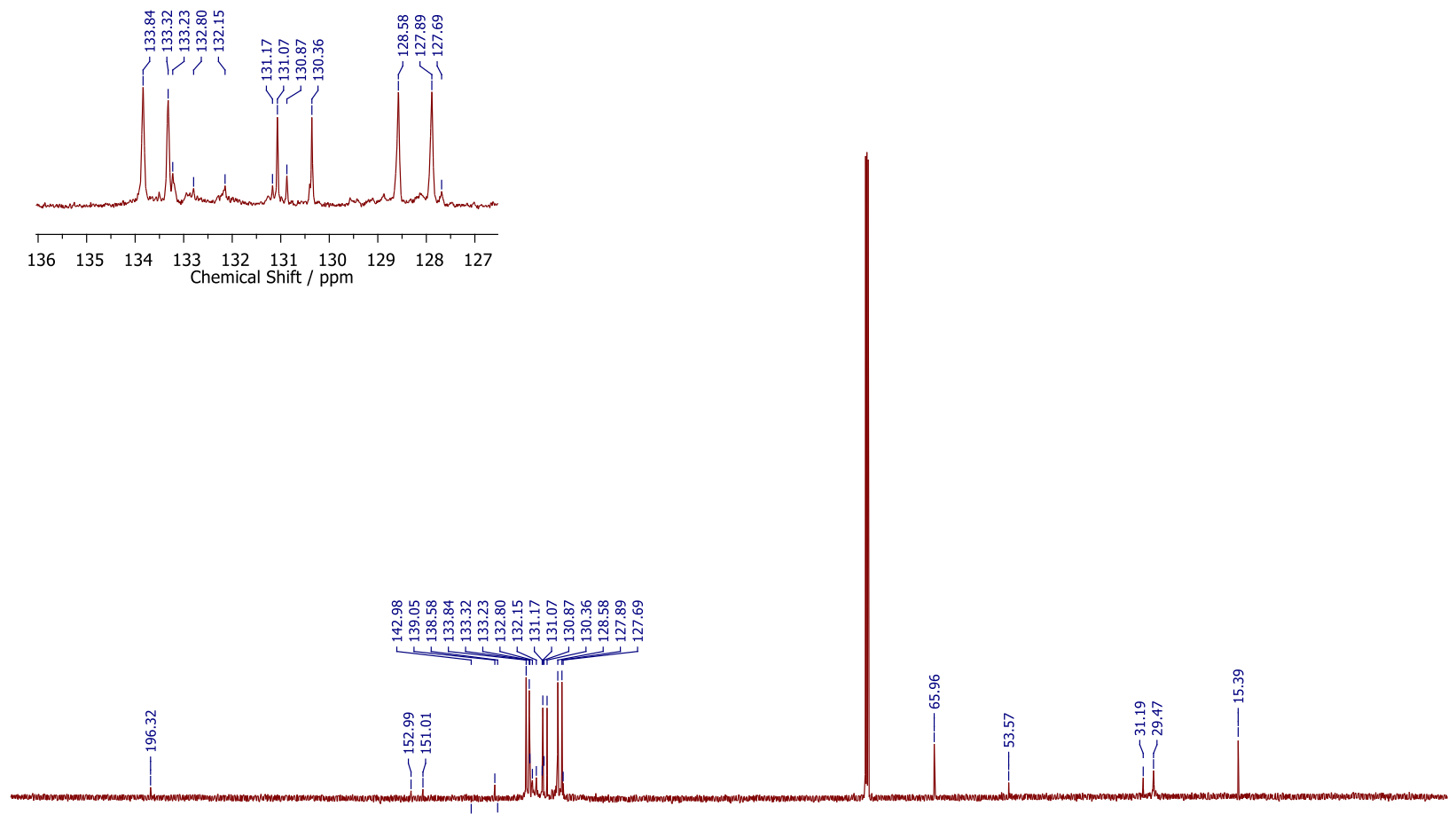

$\begin{array}{lllllllllllllllllllllll}210 & 200 & 190 & 180 & 170 & 160 & 150 & 140 & 130 & 120 & \begin{array}{c}110 \\ \text { Chemical Shift } / \mathrm{ppm}\end{array} & 80 & 70 & 60 & 50 & 40 & 30 & 20 & 10 & 0 & -10\end{array}$

Figure S28. The ${ }^{13} \mathrm{C}\left\{{ }^{1} \mathrm{H}\right\}$ NMR spectrum of [1e]OTf. The inset shows an expansion of the aromatic carbon region for clarity. 


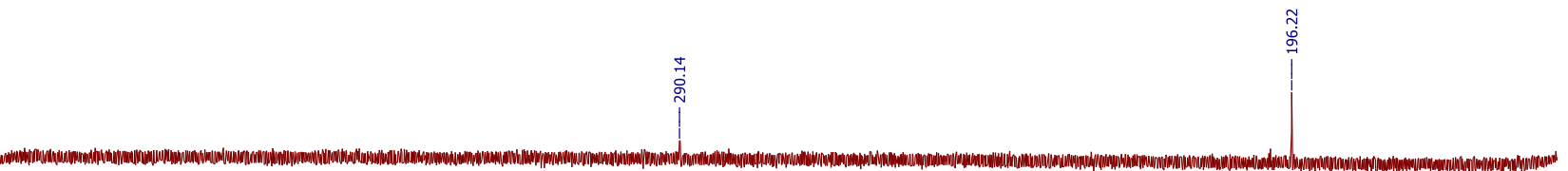

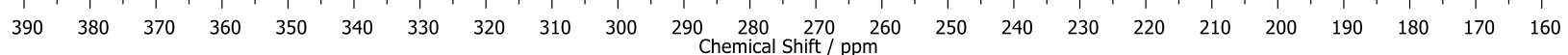

Figure S29. An expansion of the ${ }^{13} \mathrm{C}\left\{{ }^{1} \mathrm{H}\right\}$ NMR spectrum of [1e]OTf, showing the allenylidene $C(\alpha)$ and $C(\beta)$ resonances. 


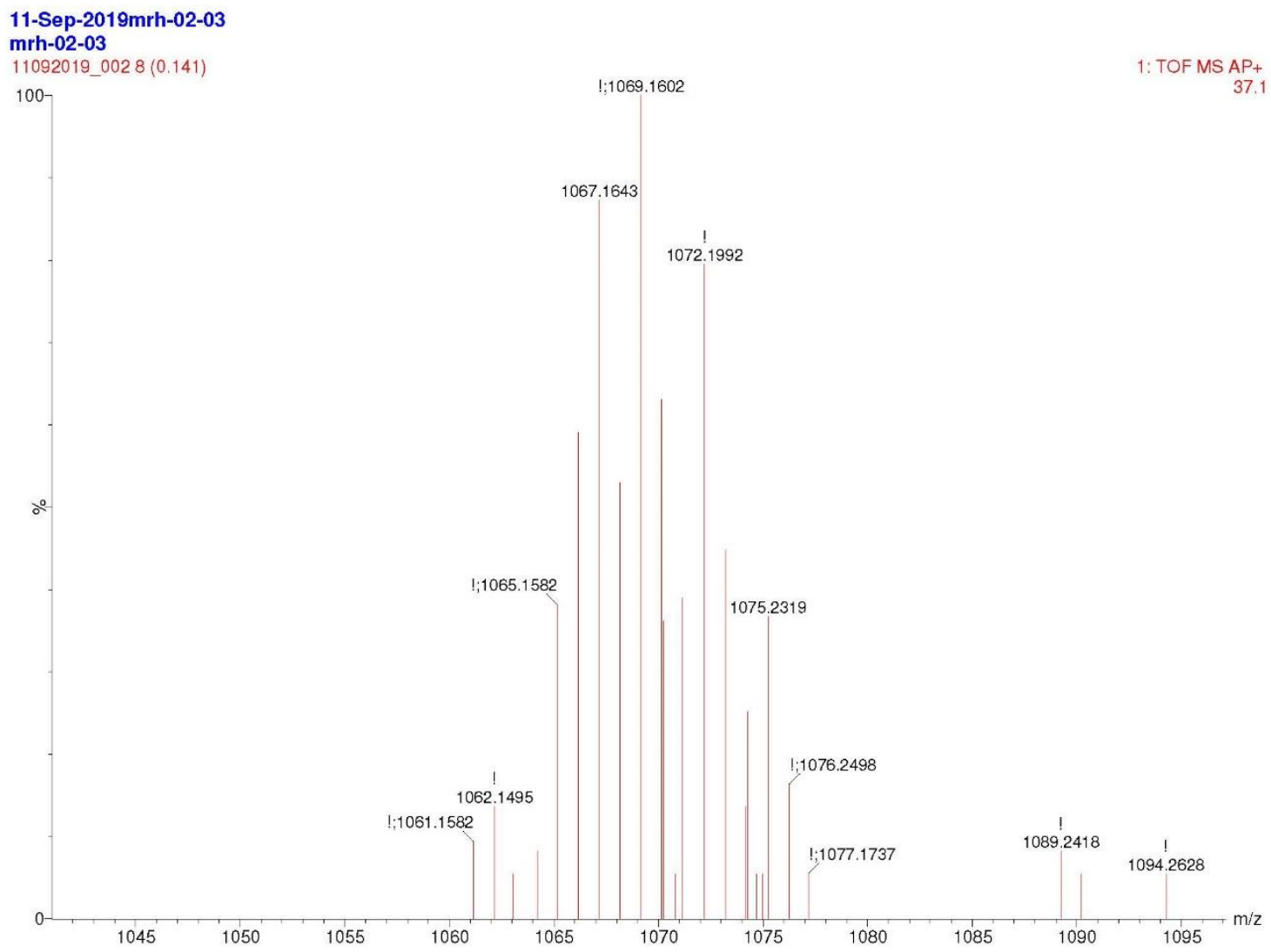

Figure S30. The APCI(+) mass spectrum of [1e]OTf. 


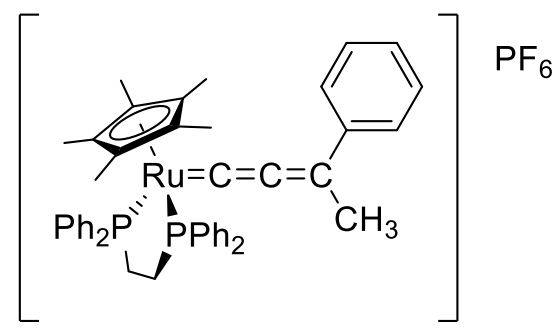

$\left[\mathrm{Ru}\{\mathrm{C}=\mathrm{C}=\mathrm{C}(\mathrm{Me}) \mathrm{Ph}\}(\mathrm{dppe}) \mathrm{Cp}^{*}\right] \mathrm{PF}_{6}\left([\mathbf{2} \mathbf{b}] \mathrm{PF}_{6}\right)$

mrh-02-47_allenylidene_400_PROTON_cdcl3_20191107_001 mrh-02-47_allenylidene

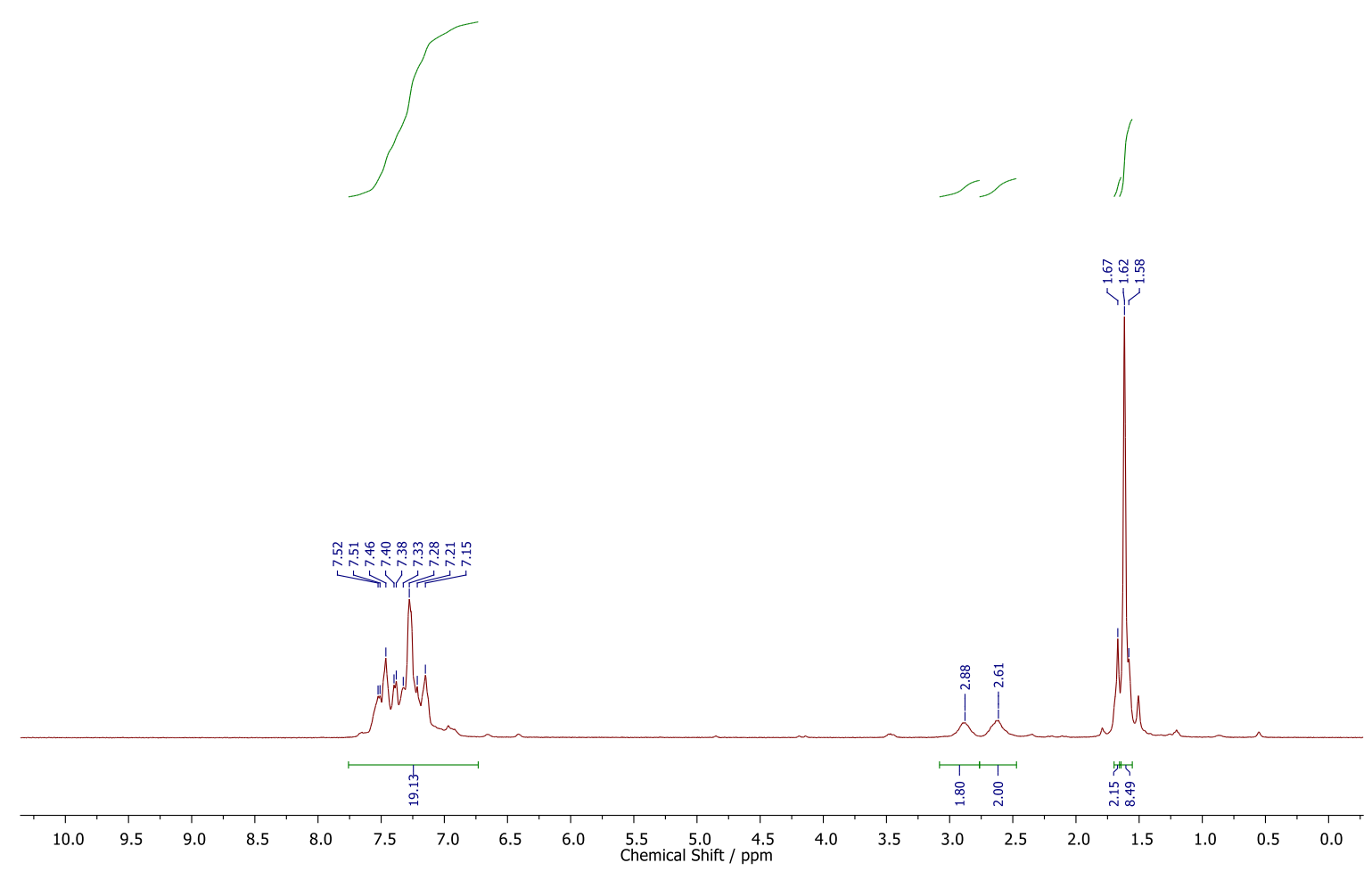

Figure S31. The ${ }^{1} \mathrm{H}$ NMR spectrum of $[\mathbf{2} \mathbf{b}] \mathrm{PF}_{6}$. 


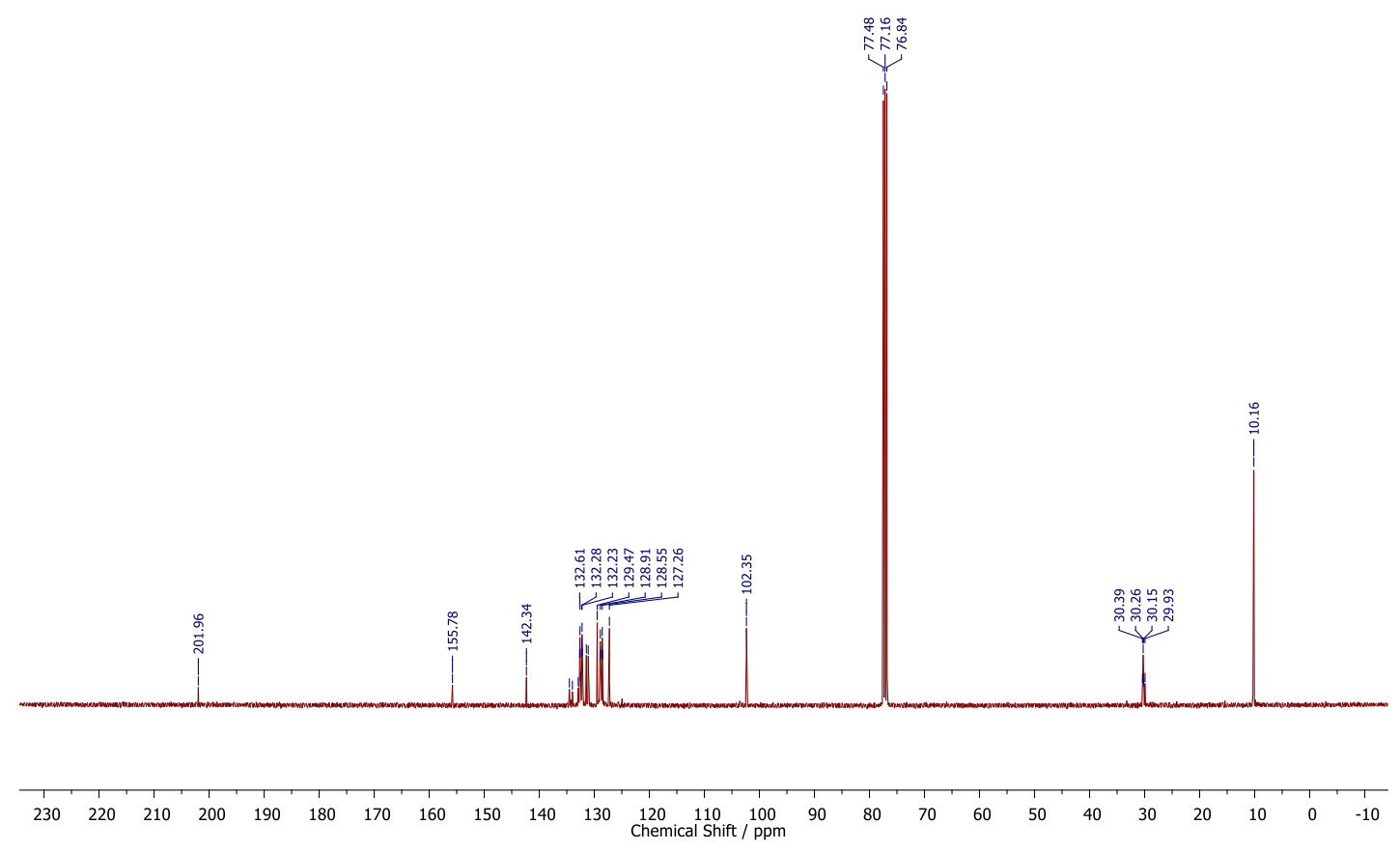

Figure S32. The ${ }^{13} \mathrm{C}\left\{{ }^{1} \mathrm{H}\right\}$ NMR spectrum of $[\mathbf{2 b}] \mathrm{PF}_{6}$.

mrh-02-47_allenylidene_400_CARBON_cdc13_20191107_001 mrh-02-47_allenylidene

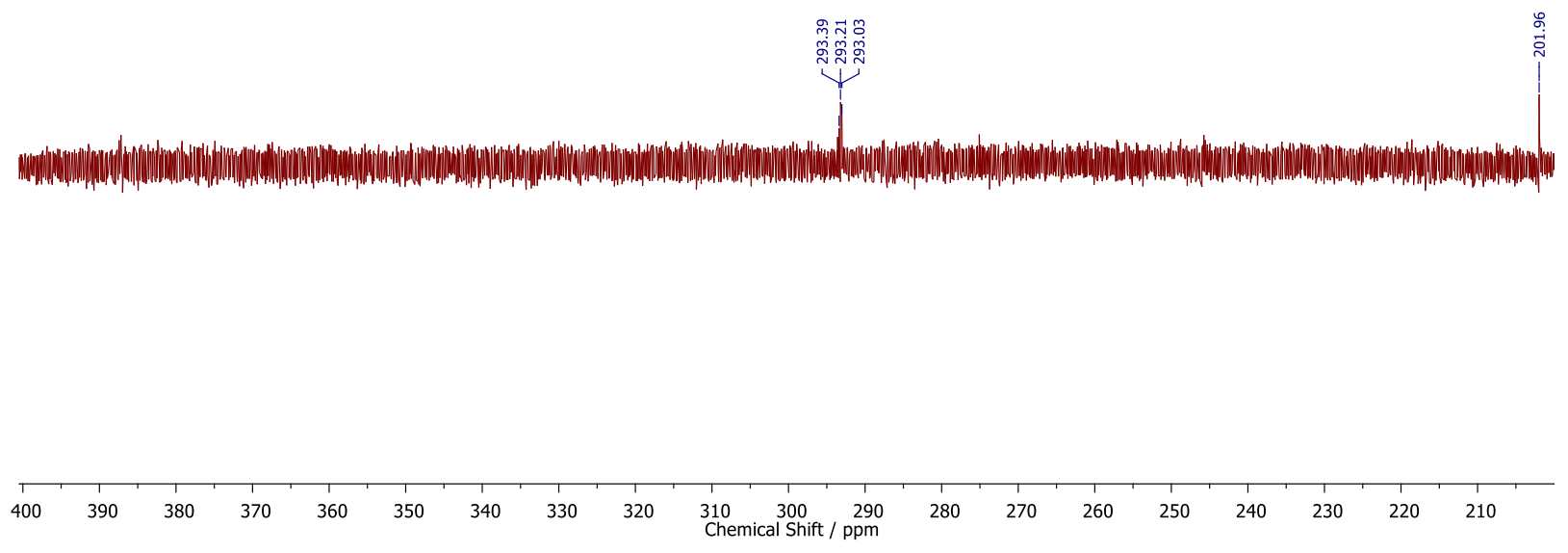

Figure S33. An expansion of the ${ }^{13} \mathrm{C}\left\{{ }^{1} \mathrm{H}\right\}$ NMR spectrum of $[\mathbf{2 b}] \mathrm{PF}_{6}$, showing the allenylidene $C(\alpha)$ and $C(\beta)$ resonances. 


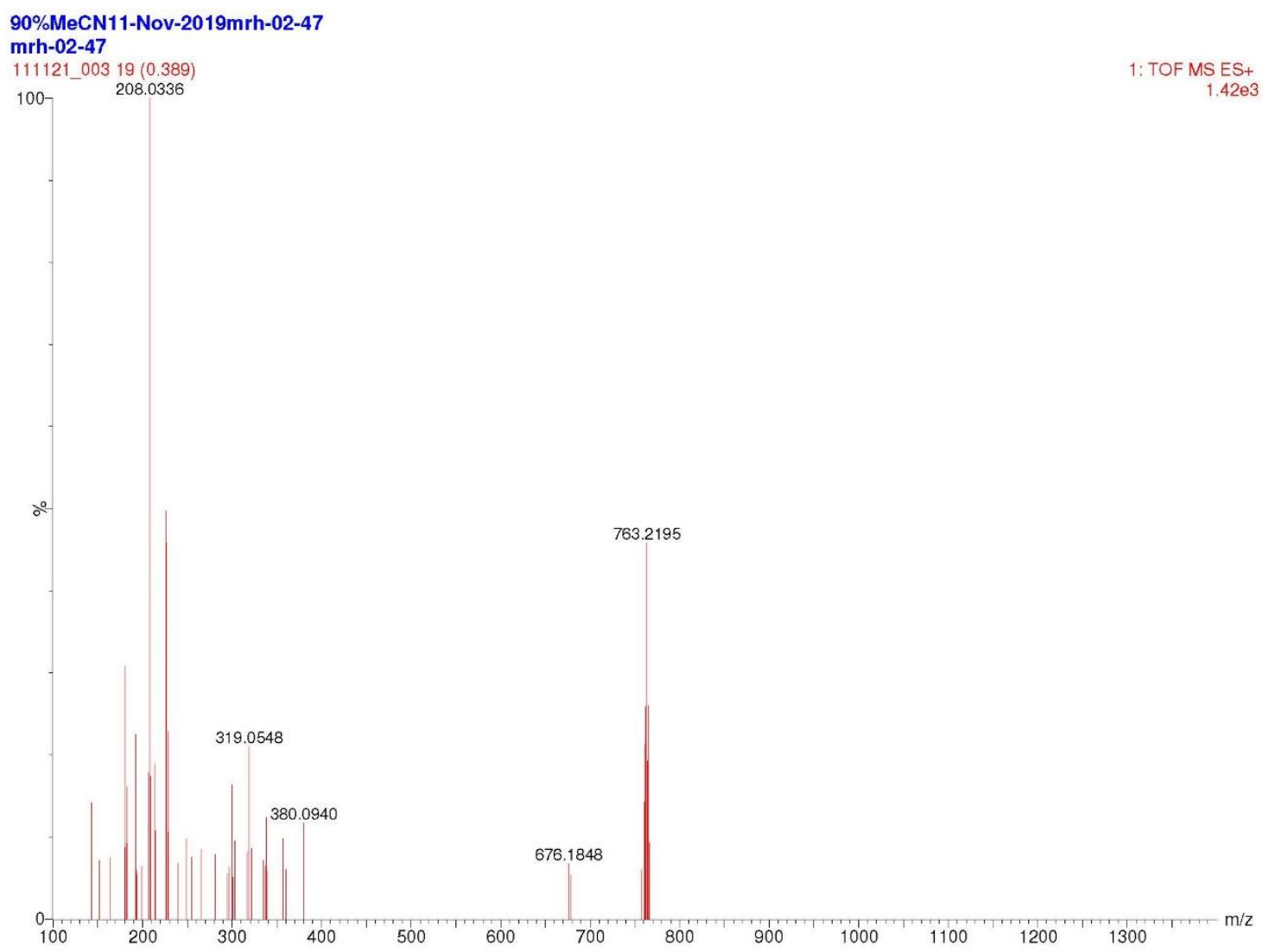

Figure S34. The ESI(+) mass spectrum of $[\mathbf{2 b}] \mathrm{PF}_{6}$. 


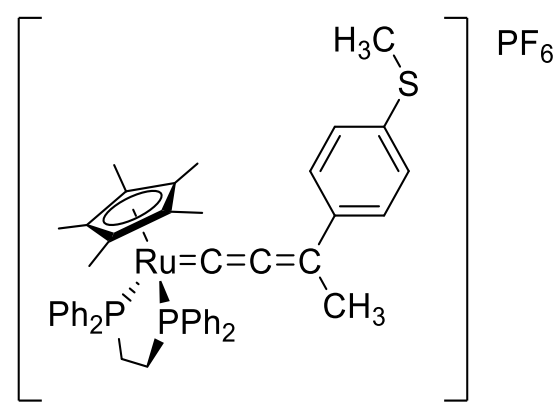

$\left[\mathrm{Ru}\left\{\mathrm{C}=\mathrm{C}=\mathrm{C}(\mathrm{Me})\left(4-\mathrm{MeS}-\mathrm{C}_{6} \mathrm{H}_{4}\right)\right\}(\mathrm{dppe}) \mathrm{Cp}^{*}\right] \mathrm{PF}_{6}\left([\mathbf{2 d}] \mathrm{PF}_{6}\right)$
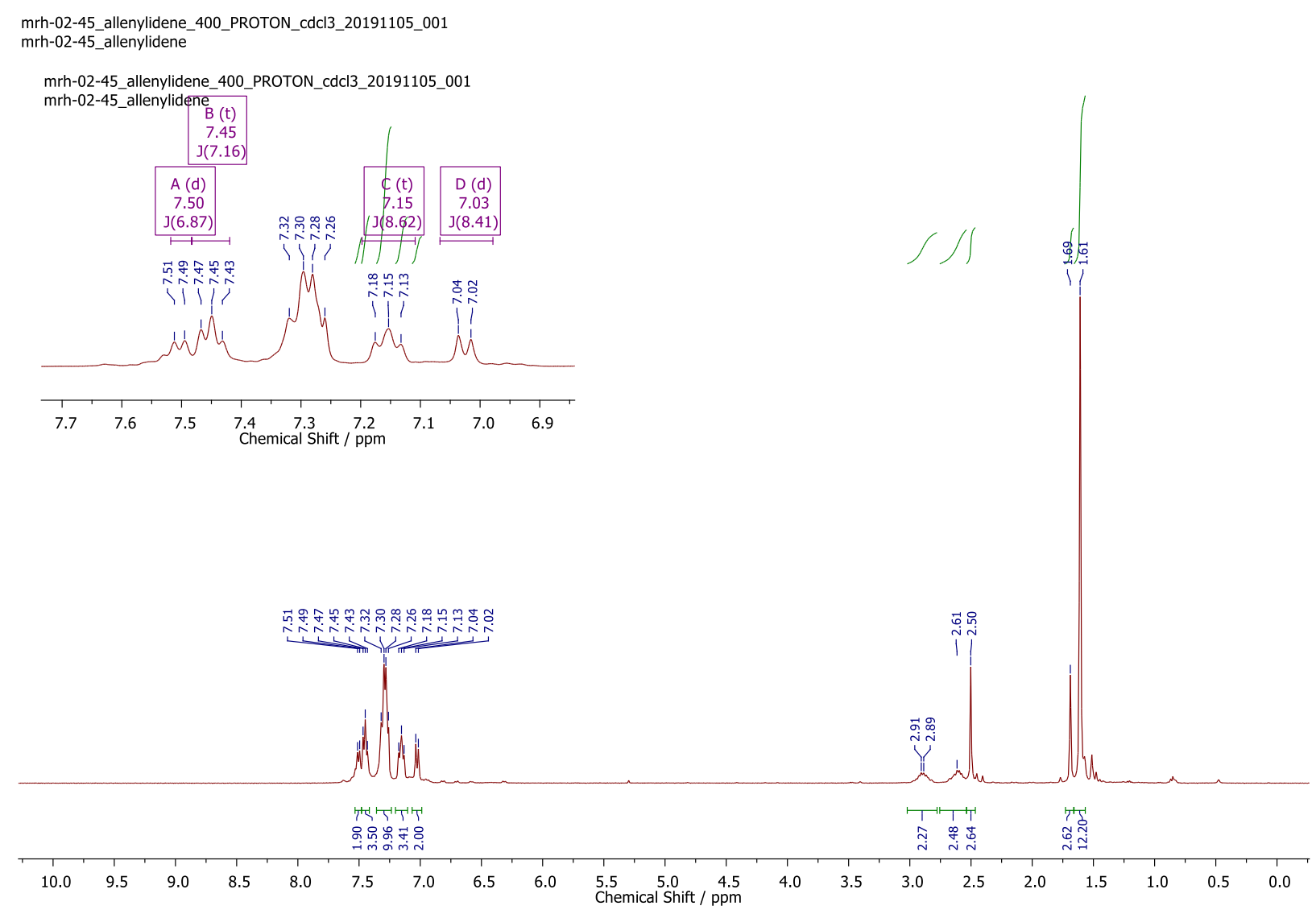

Figure S35. The ${ }^{1} \mathrm{H}$ NMR spectrum of $[\mathbf{2 d}] \mathrm{PF}_{6}$. The inset shows an expansion of the aromatic region for clarity. 
mrh-02-45_allenylidene_400_CARBON_cdc13_20191106_001 mrhmPR=A2_-49Healy mrh-02-45_allenylidene
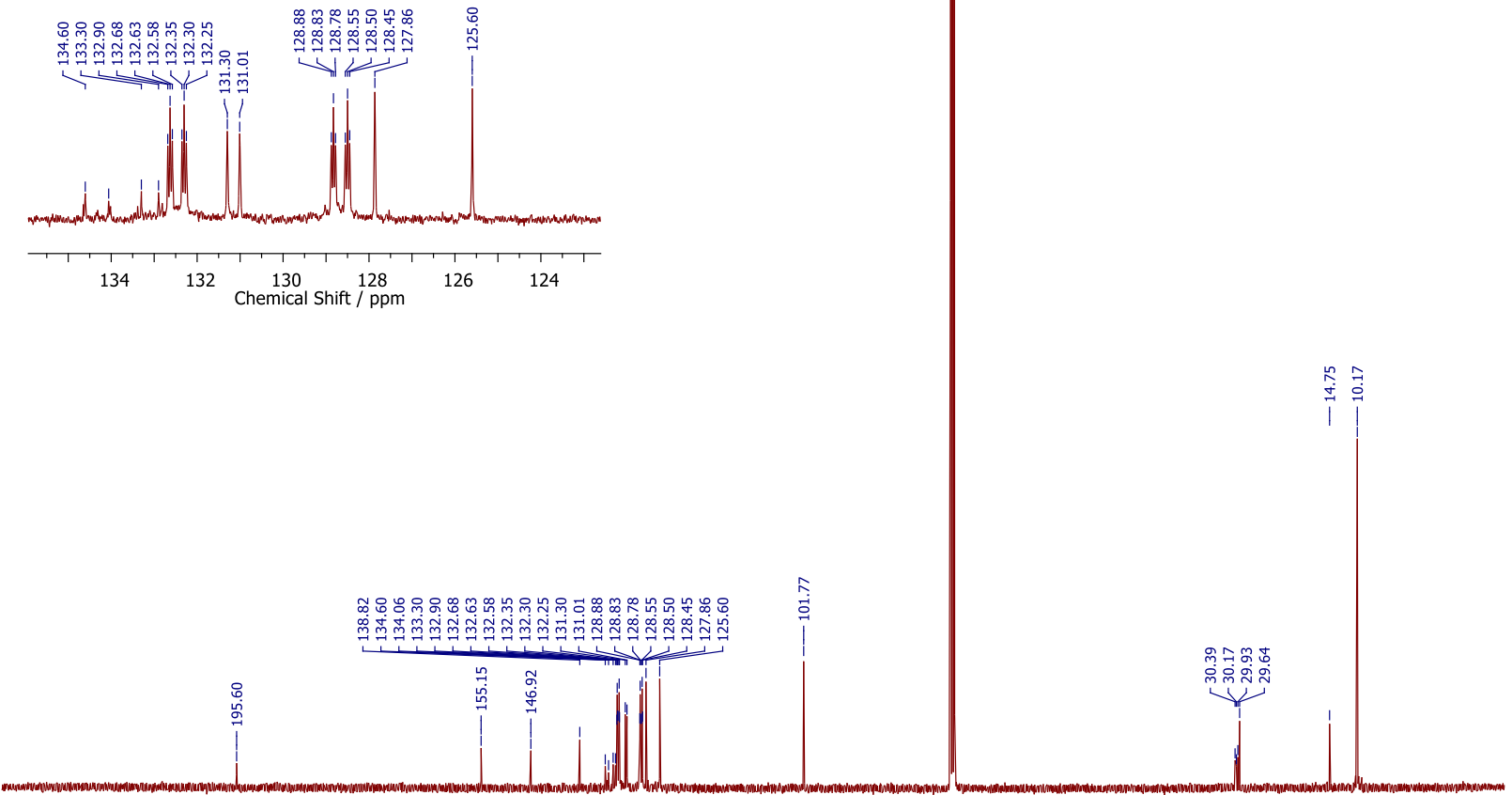

$\begin{array}{lllllllllllllllllllllllllllllllllll}230 & 220 & 210 & 200 & 190 & 180 & 170 & 160 & 150 & 140 & 130 & 120 & 110 & 100 & 90 & 80 & 70 & 60 & 50 & 40 & 30 & 20 & 10 & 0 & -10\end{array}$

Figure S36. The ${ }^{13} \mathrm{C}\left\{{ }^{1} \mathrm{H}\right\}$ NMR spectrum of $[\mathbf{2 d}] \mathrm{PF}_{6}$. The inset shows an expansion of the aromatic carbon region for clarity. 
mrh-02-45_allenylidene_400_CARBON_cdc13_20191105_001 mrh-02-45_allenylidene

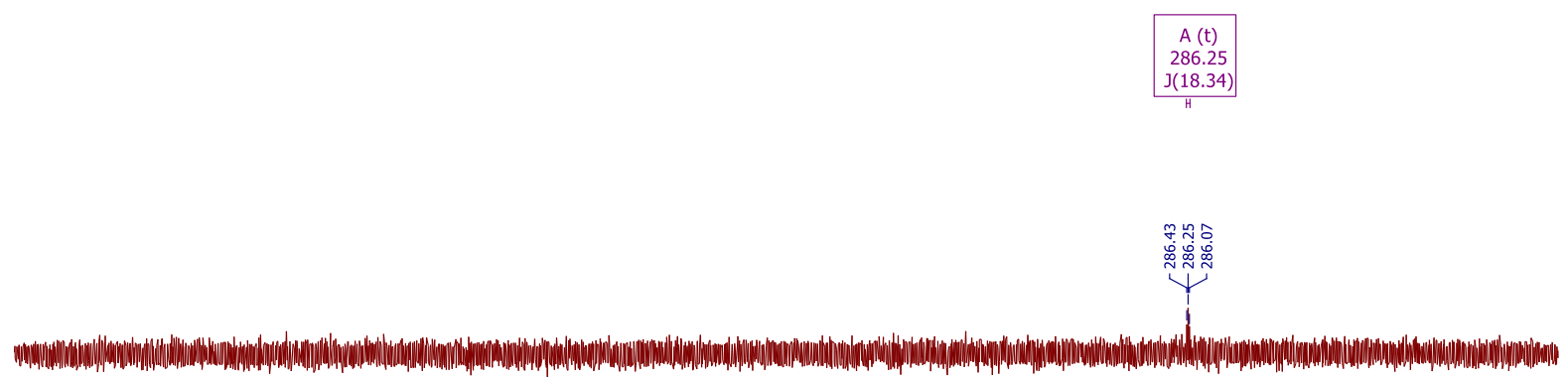

\begin{tabular}{|c|c|c|c|c|c|c|c|c|c|c|c|c|c|c|c|c|c|c|c|c|}
\hline 440 & 430 & 420 & 410 & 400 & 390 & 380 & 370 & 360 & $\begin{array}{l}350 \\
\text { Chemica }\end{array}$ & $\begin{array}{l}340 \\
\text { Shift }\end{array}$ & $\begin{array}{c}330 \\
\mathrm{ppm}\end{array}$ & 320 & 310 & 300 & 290 & 280 & 270 & 260 & 250 & 240 \\
\hline
\end{tabular}

Figure S37. An expansion of the ${ }^{13} \mathrm{C}\left\{{ }^{1} \mathrm{H}\right\}$ NMR spectrum of $[\mathbf{2 d}] \mathrm{PF}_{6}$, showing the allenylidene $\mathrm{C}(\alpha)$ resonance. 


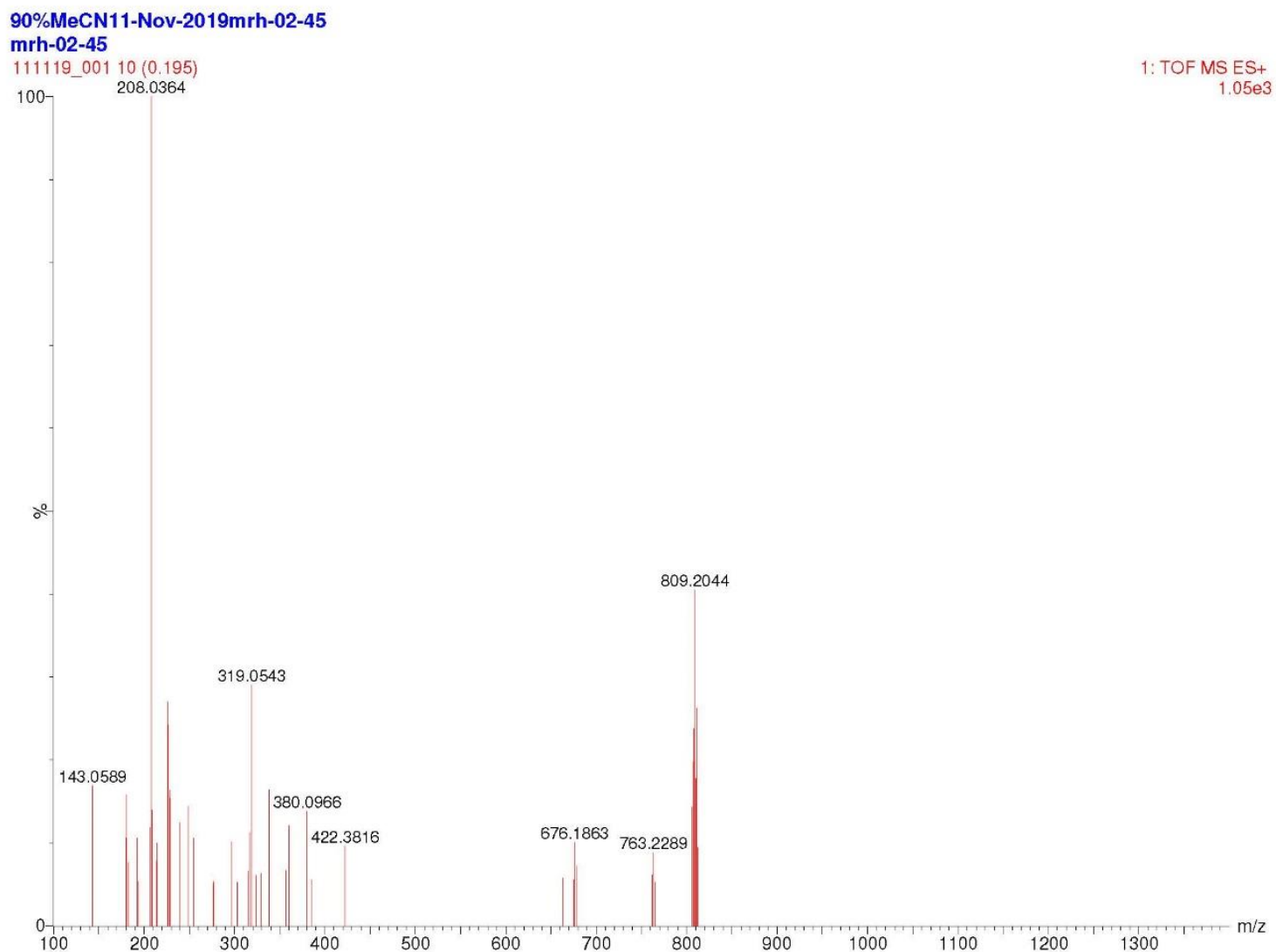

Figure S38. The ESI(+) mass spectrum of $[\mathbf{2 d}] \mathrm{PF}_{6}$. 
Alkenylacetylides

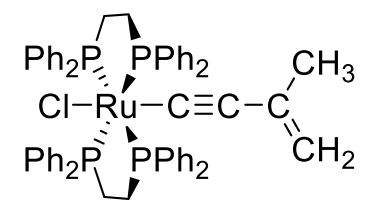

trans $-\left[\mathrm{Ru}\left\{\mathrm{C} \equiv \mathrm{CC}\left(=\mathrm{CH}_{2}\right) \mathrm{Me}\right\} \mathrm{Cl}(\mathrm{dppe})_{2}\right]$ (3a)

MRH-01-35

MRH-01-35
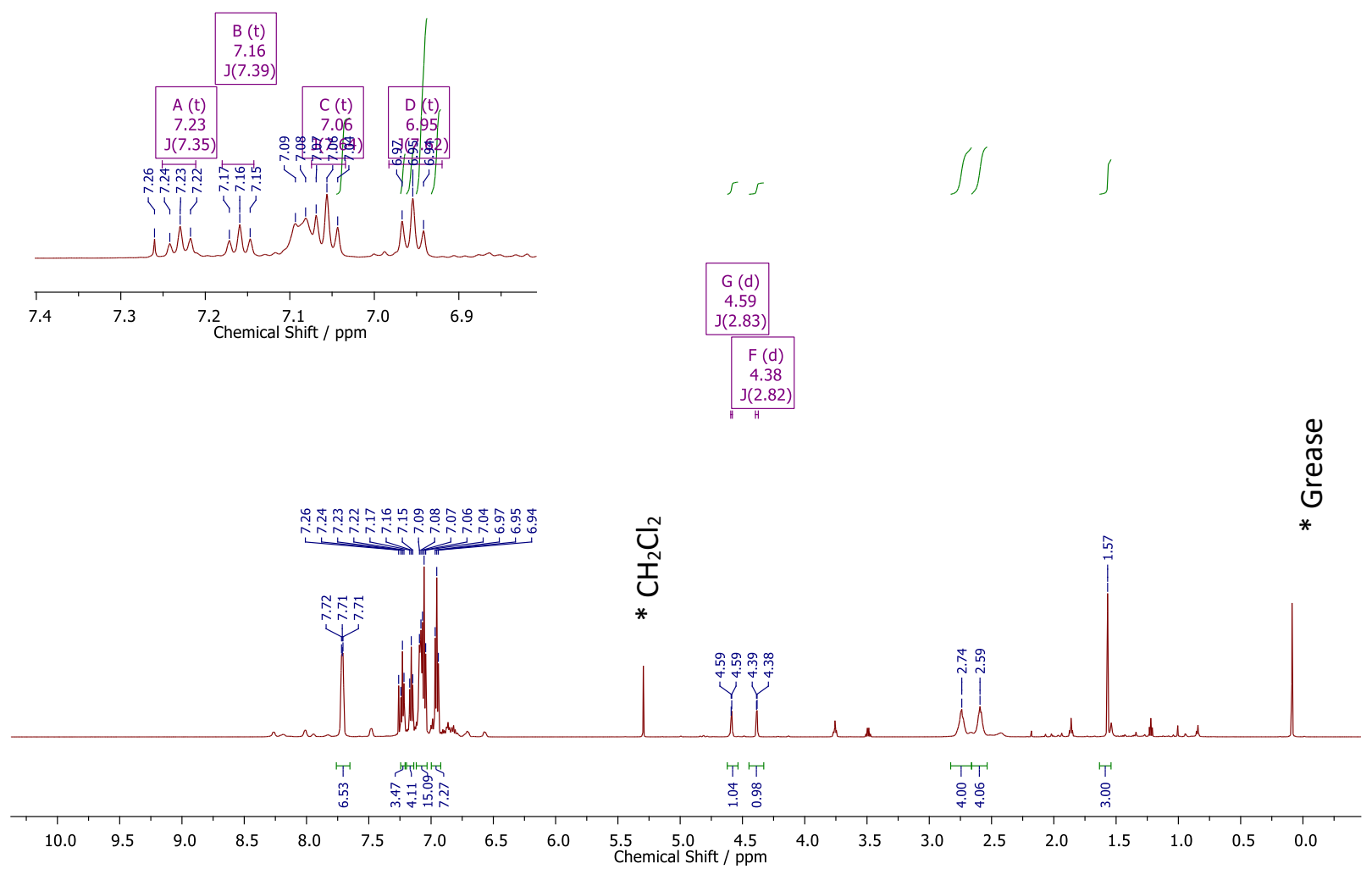

Figure S39. The ${ }^{1} \mathrm{H}$ NMR spectrum of 3a. The inset shows an expansion of the aromatic region for clarity. 


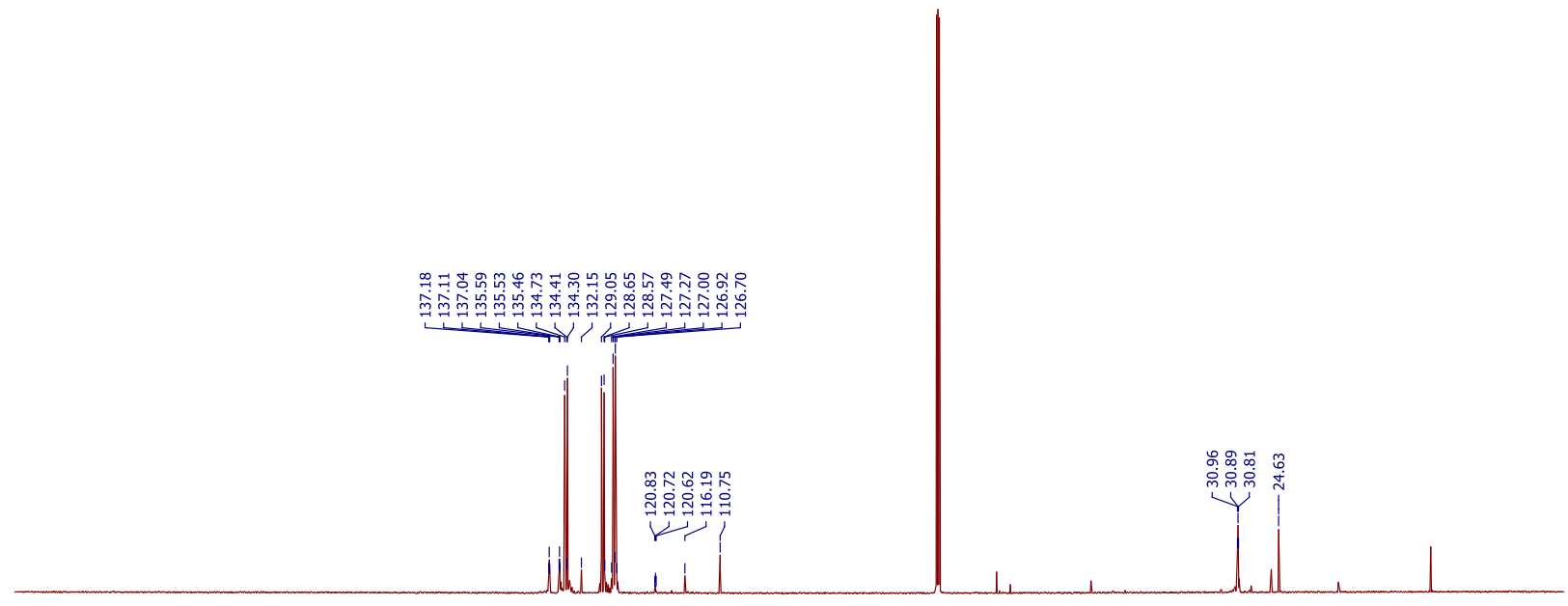

$\begin{array}{lllllllllllllllllllllllllllllllll} & 210 & 200 & 190 & 180 & 170 & 160 & 150 & 140 & 130 & 120 & 110 & 100 & 90 & 80 & 70 & 60 & 50 & 40 & 30 & 20 & 10 & 0 & -10\end{array}$

Figure S40. The ${ }^{13} \mathrm{C}\left\{{ }^{1} \mathrm{H}\right\}$ NMR spectrum of $\mathbf{3 a}$. 


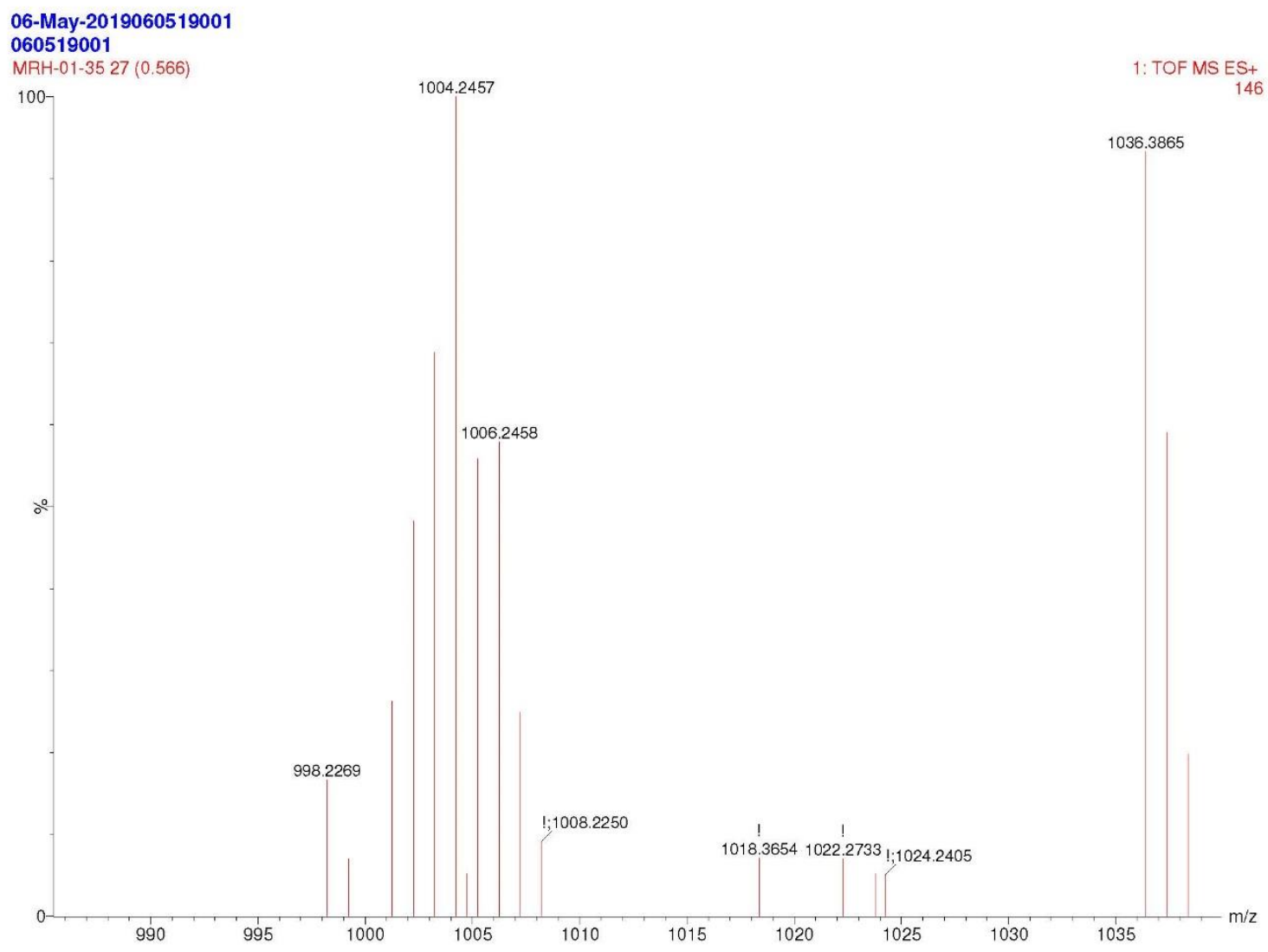

Figure S41. The ESI(+) mass spectrum of 3a. 


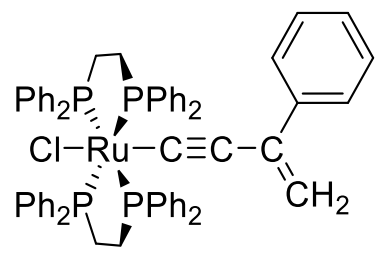

trans $-\left[\mathrm{Ru}\left\{\mathrm{C} \equiv \mathrm{CC}\left(=\mathrm{CH}_{2}\right) \mathrm{Ph}\right\} \mathrm{Cl}(\mathrm{dppe})_{2}\right](\mathbf{3 b})$

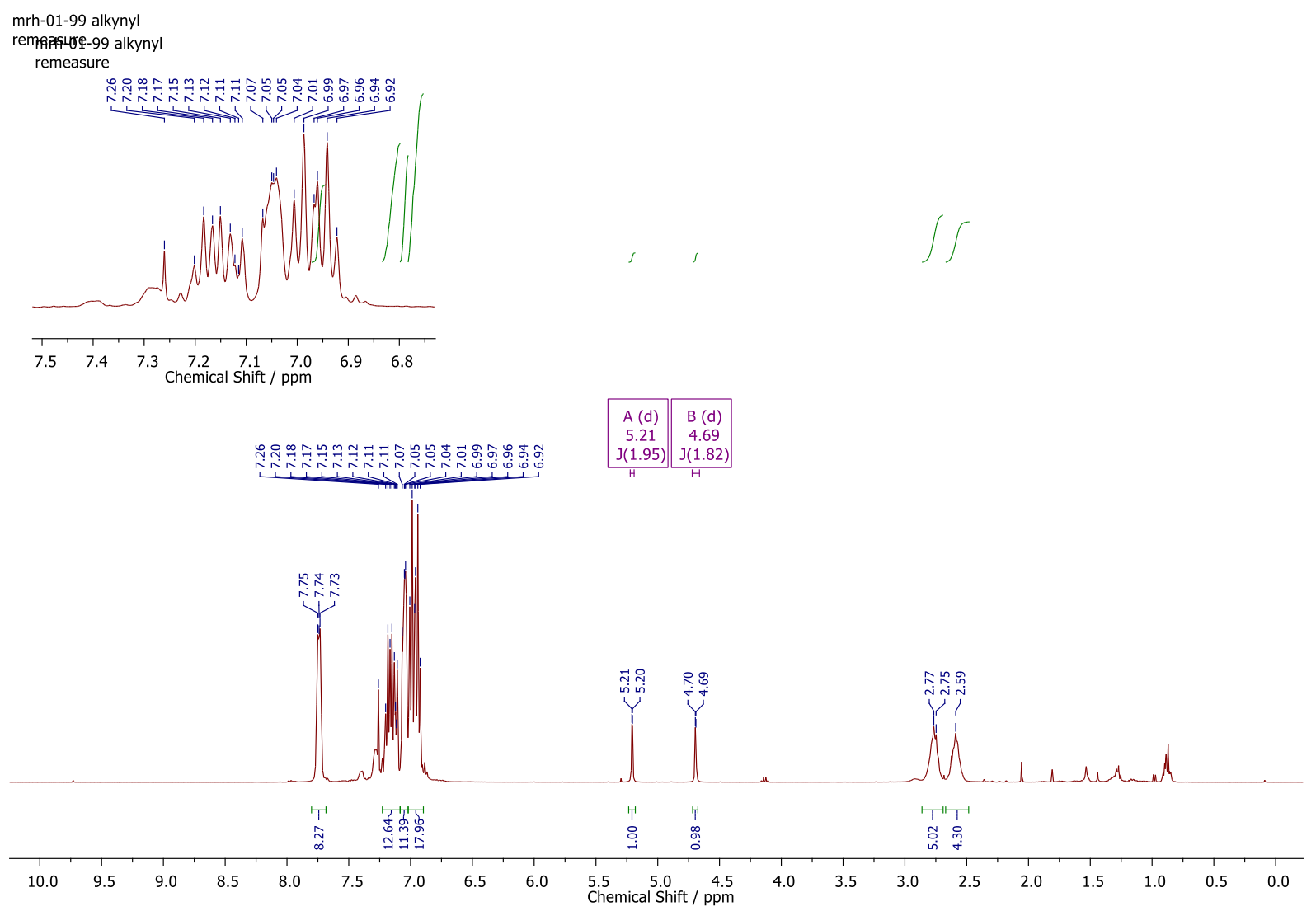

Figure S42. The ${ }^{1} \mathrm{H}$ NMR spectrum of $\mathbf{3 b}$. The inset shows an expansion of the aromatic region for clarity. 

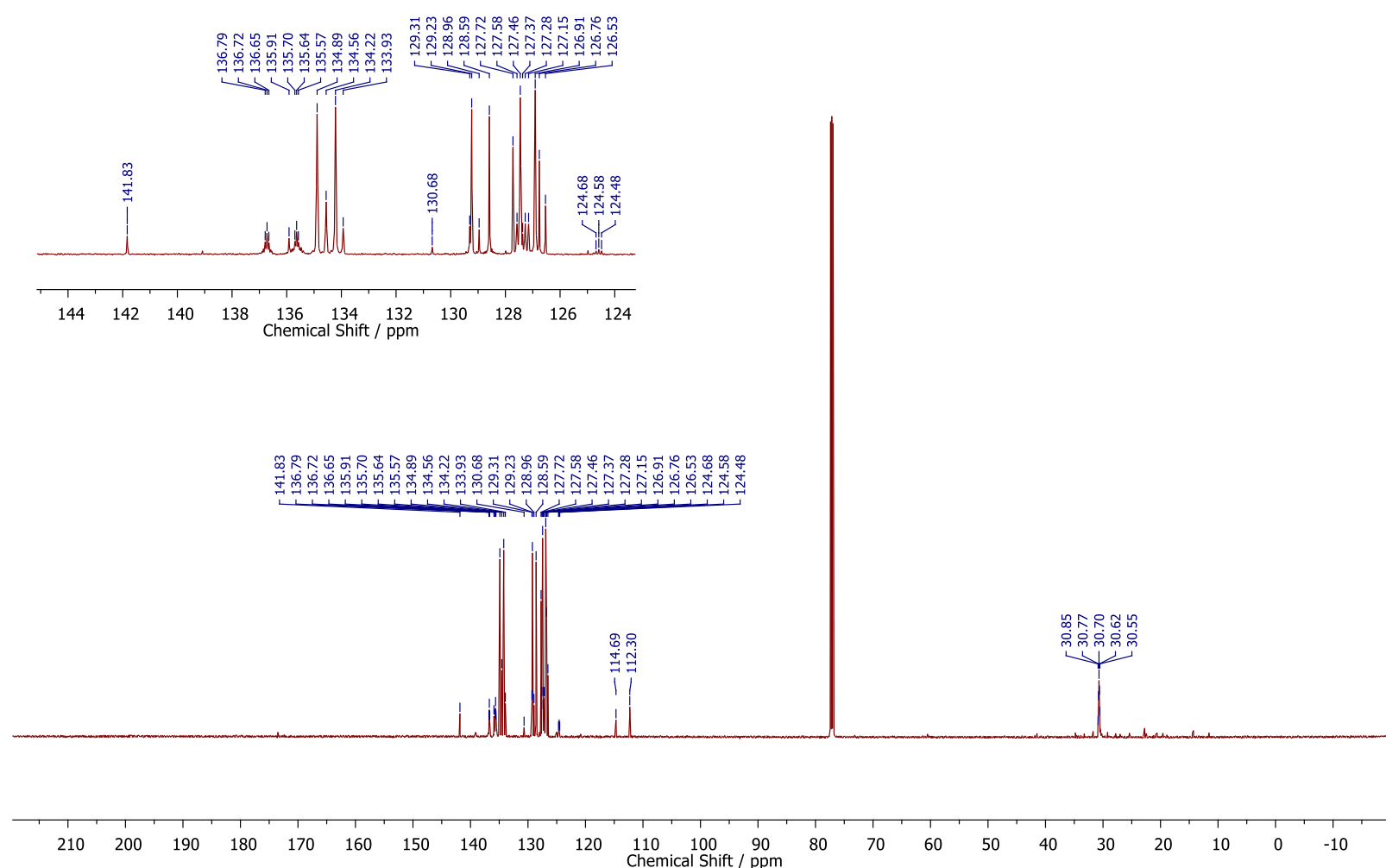

Figure S43. The ${ }^{13} \mathrm{C}\left\{{ }^{1} \mathrm{H}\right\}$ NMR spectrum of 3b. The inset shows an expansion of the aromatic carbon region for clarity. 
24-May-2019mrh-01-59 a

mrh-01-59 a

$24051900515(0.301)$

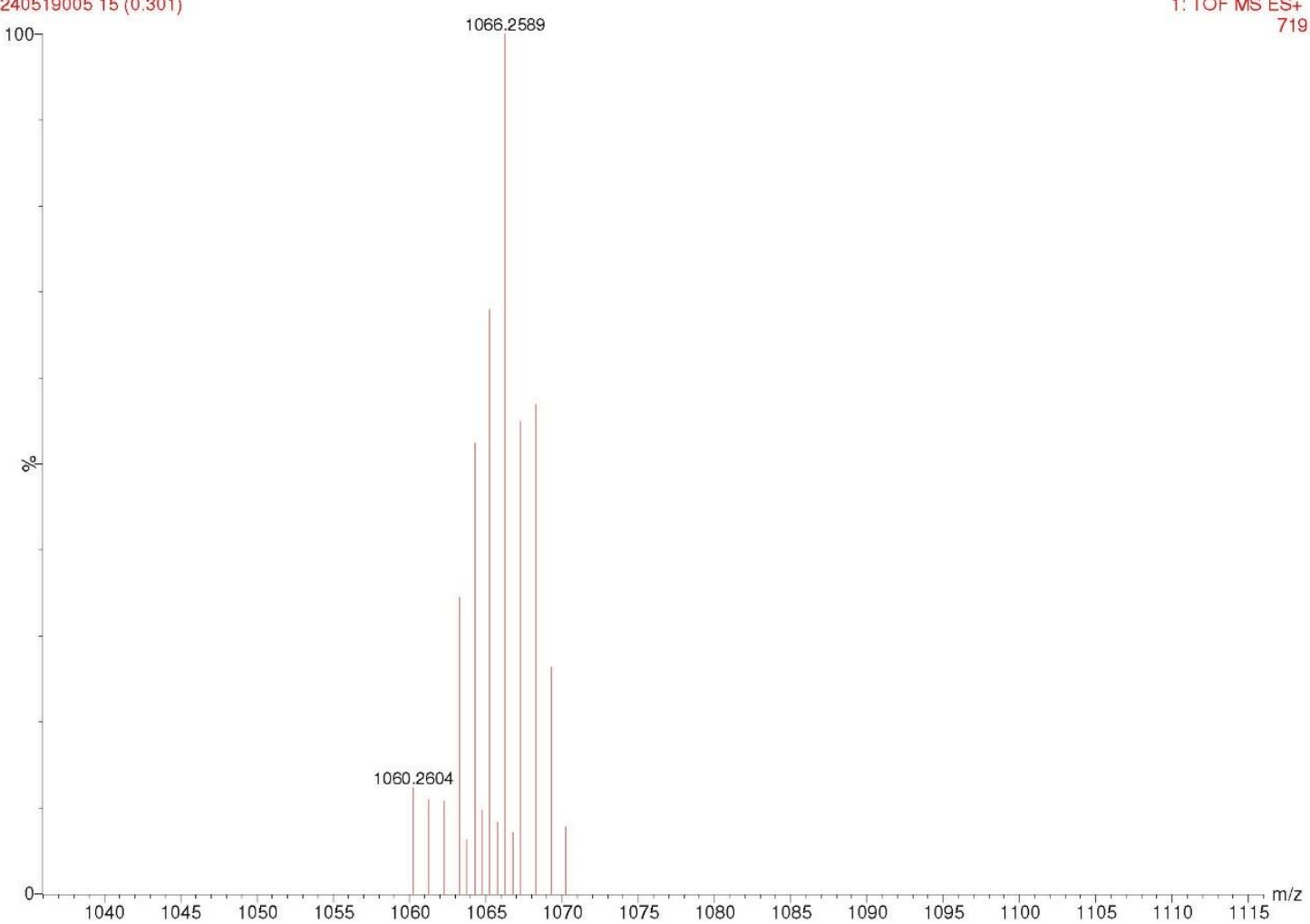

Figure S44. The ESI(+) mass spectrum of $\mathbf{3 b}$. 


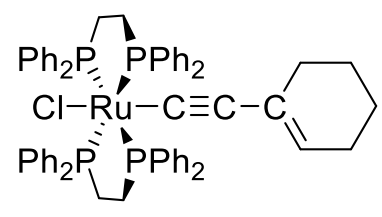

trans $-\left[\mathrm{Ru}\left\{\mathrm{C} \equiv \mathrm{CC}\left({ }^{c} \mathrm{C}_{6} \mathrm{H}_{9}\right)\right\} \mathrm{Cl}(\mathrm{dppe})_{2}\right](\mathbf{3 c})$

mrh-01-63 b carbon
mrh-01-63 b carbon
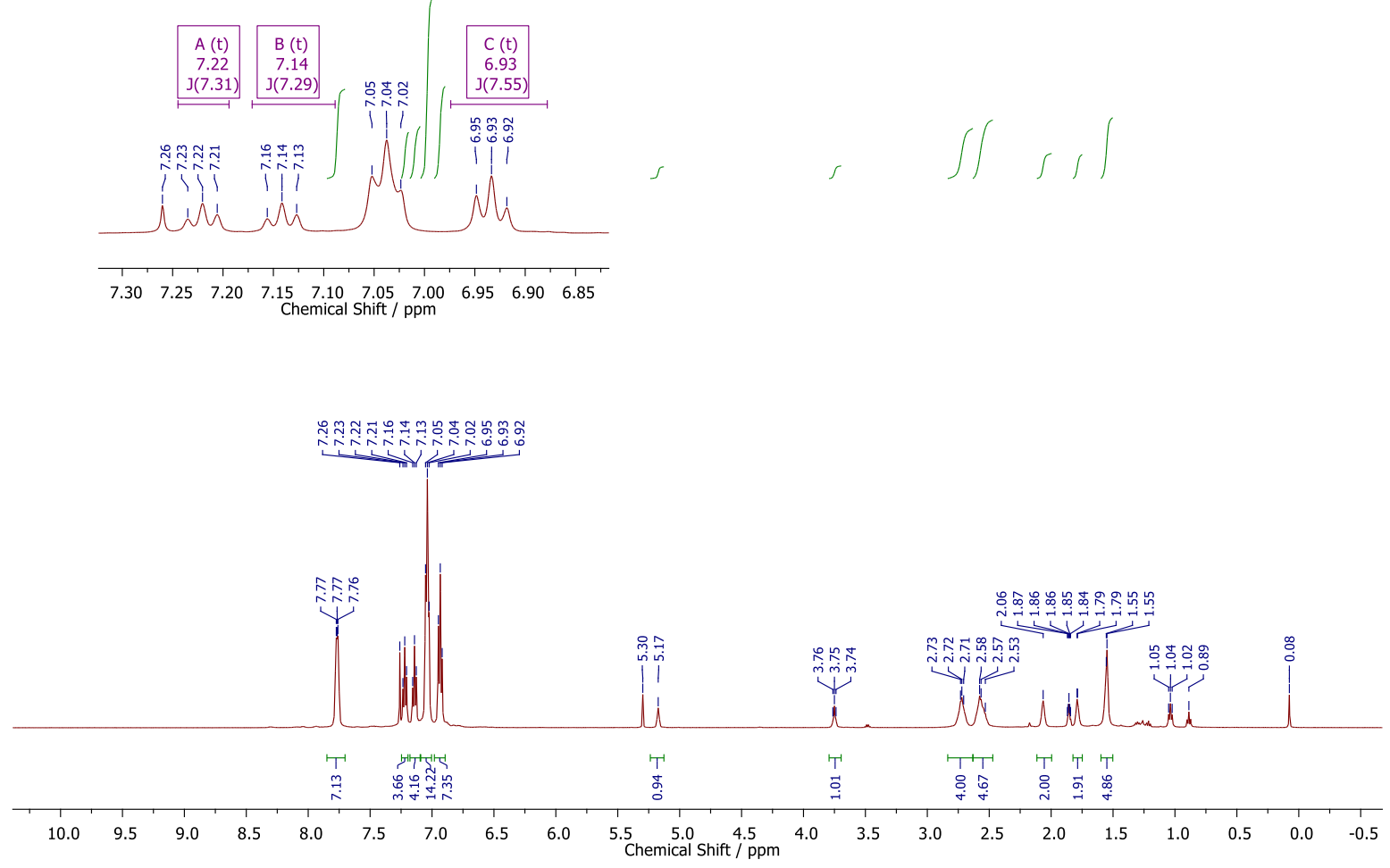

Figure S45. The ${ }^{1} \mathrm{H}$ NMR spectrum of 3c. The inset shows an expansion of the aromatic region for clarity. 


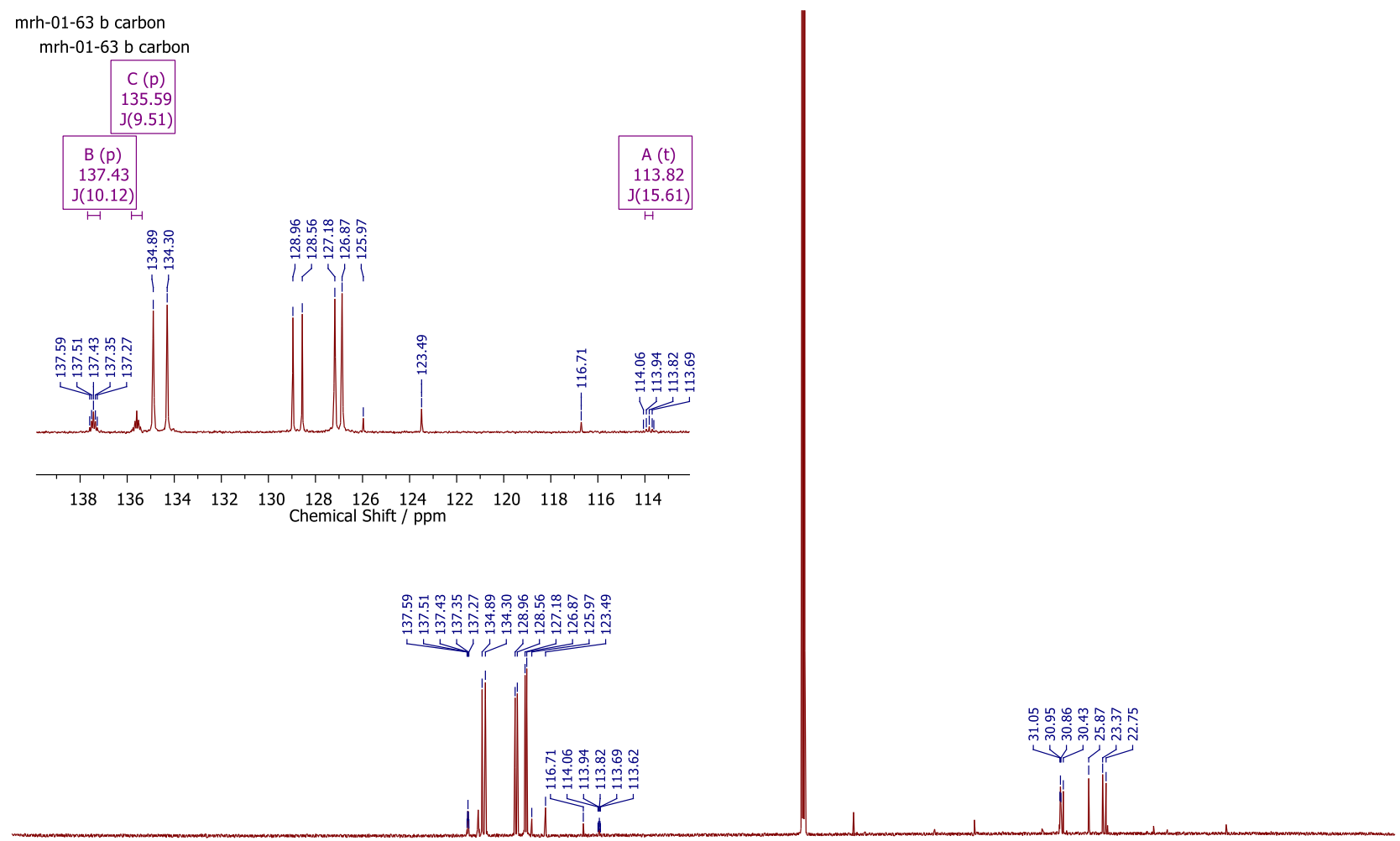

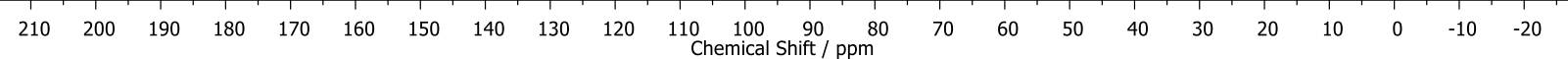

Figure S46. The ${ }^{13} \mathrm{C}\left\{{ }^{1} \mathrm{H}\right\}$ NMR spectrum of 3c. The inset shows an expansion of the aromatic carbon region for clarity. 


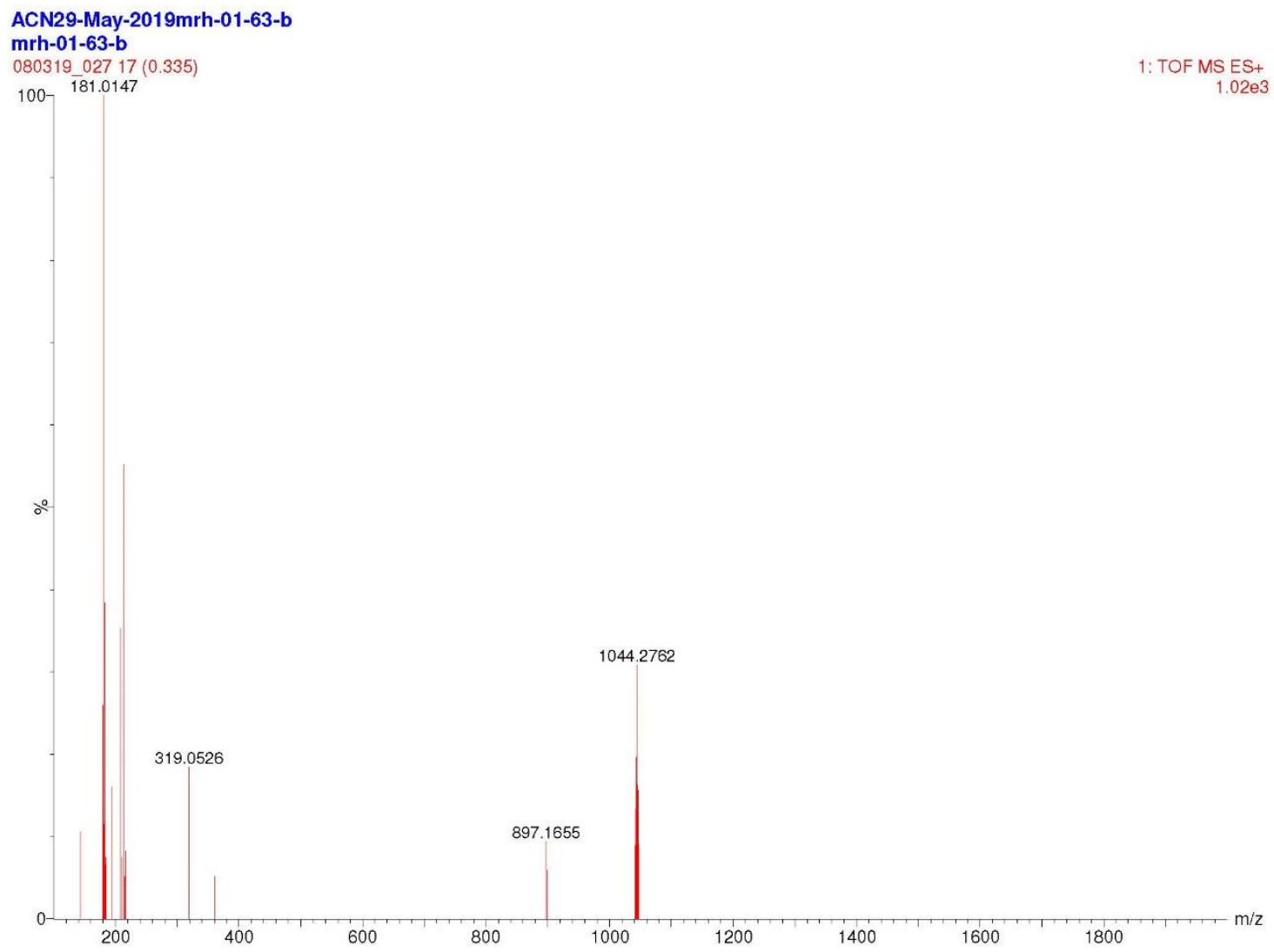

Figure S47. The ESI(+) mass spectrum of 3c. 


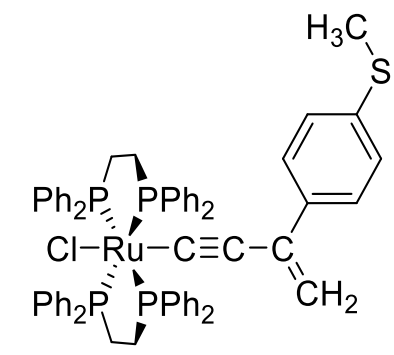

trans- $\left[\mathrm{Ru}\left\{\mathrm{C} \equiv \mathrm{CC}\left(=\mathrm{CH}_{2}\right)\left(4-\mathrm{MeS}_{-} \mathrm{C}_{6} \mathrm{H}_{4}\right)\right\} \mathrm{Cl}(\mathrm{dppe})_{2}\right](\mathbf{3 d})$

mrh-02-03 alkynyl
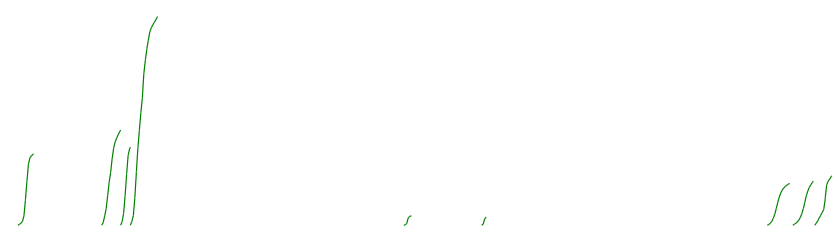

$$
\begin{array}{|c||c|}
\hline \text { A (d) } & \text { B (d) } \\
5.19 & 4.69 \\
\hline
\end{array}
$$

\begin{tabular}{c|c}
\hline$J(1.83)$ & $\mathrm{J}(1.73)$ \\
\hline
\end{tabular}

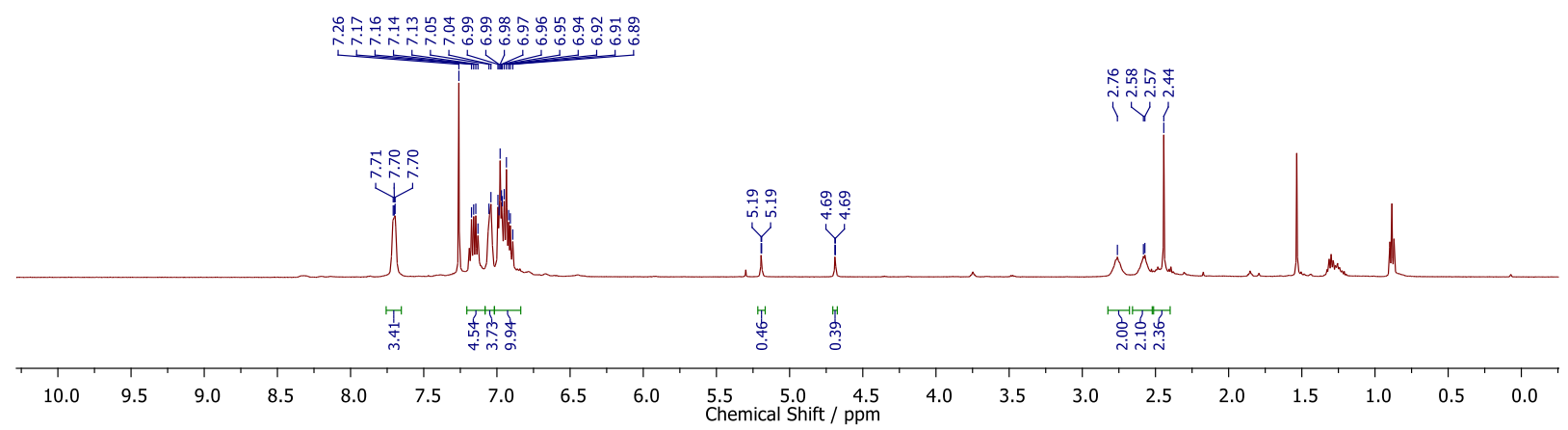

Figure S48. The ${ }^{1} \mathrm{H}$ NMR spectrum of $\mathbf{3 d}$. 


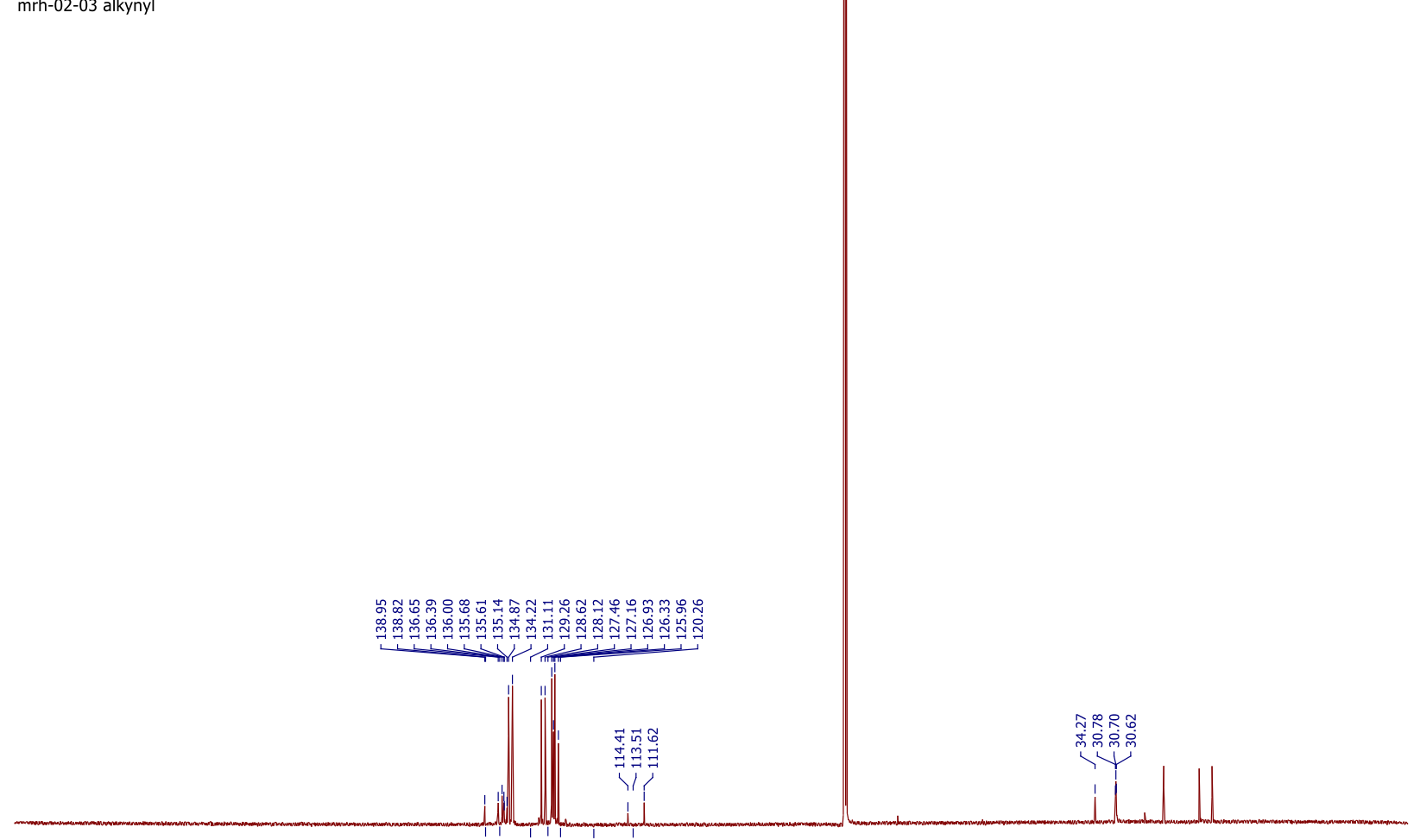

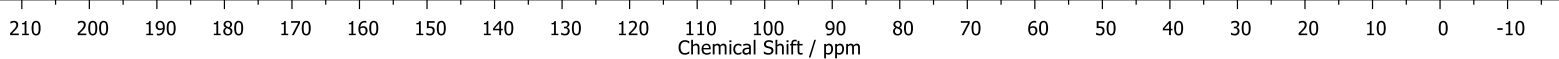

Figure S49. The ${ }^{13} \mathrm{C}\left\{{ }^{1} \mathrm{H}\right\}$ NMR spectrum of $3 d$. 


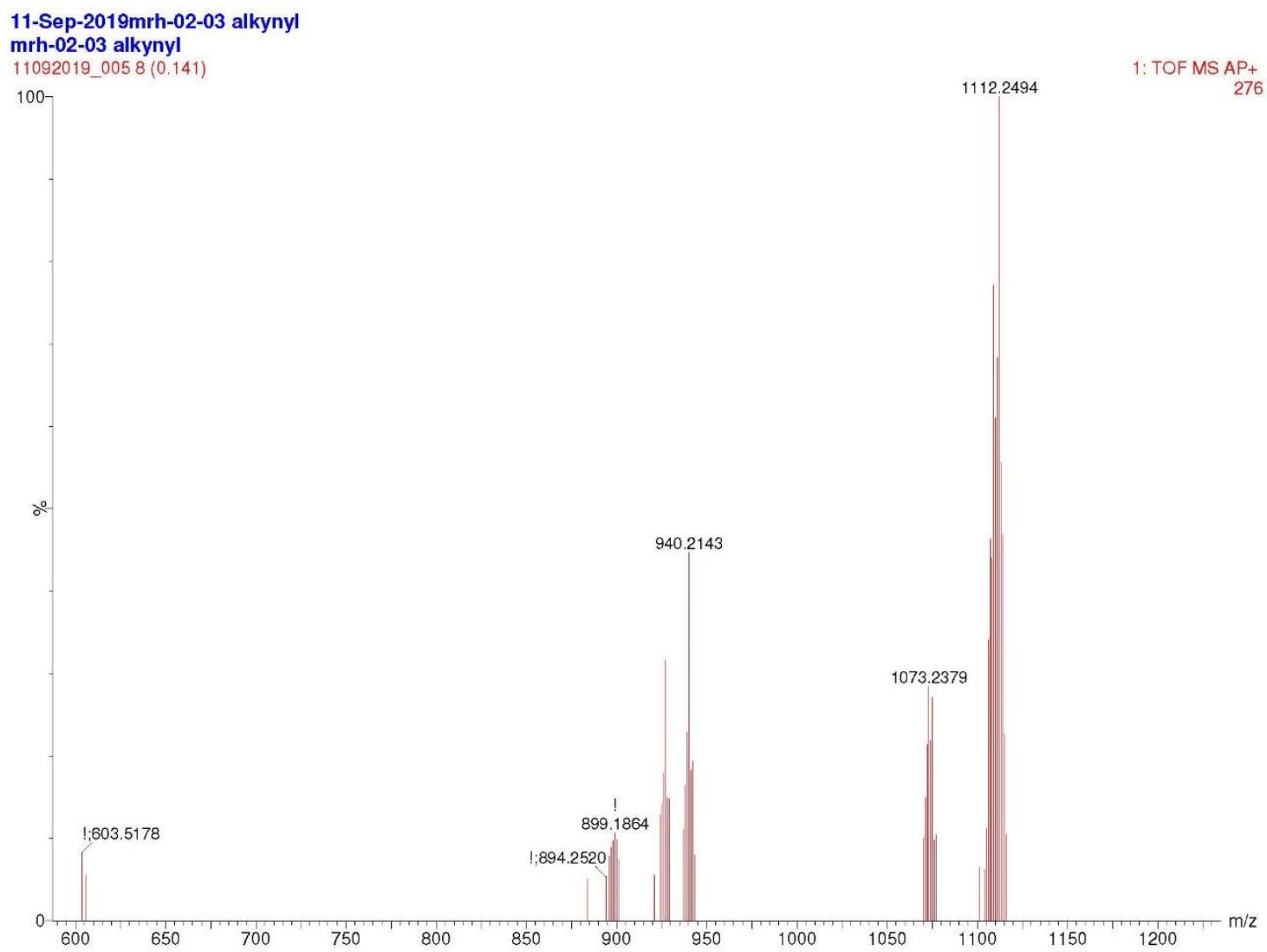

Figure S50. The APCI(+) mass spectrum of 3d. 


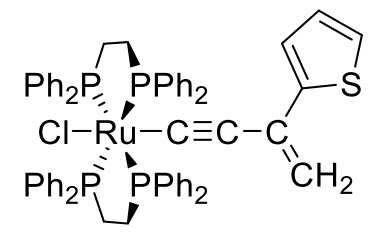

trans $-\left[\mathrm{Ru}\left\{\mathrm{C} \equiv \mathrm{CC}\left(=\mathrm{CH}_{2}\right)\left(2-{ }^{c} \mathrm{C}_{4} \mathrm{H}_{3} \mathrm{~S}\right)\right\} \mathrm{Cl}(\mathrm{dppe})_{2}\right](\mathbf{3 e})$

mrh-02-08 alkynyl

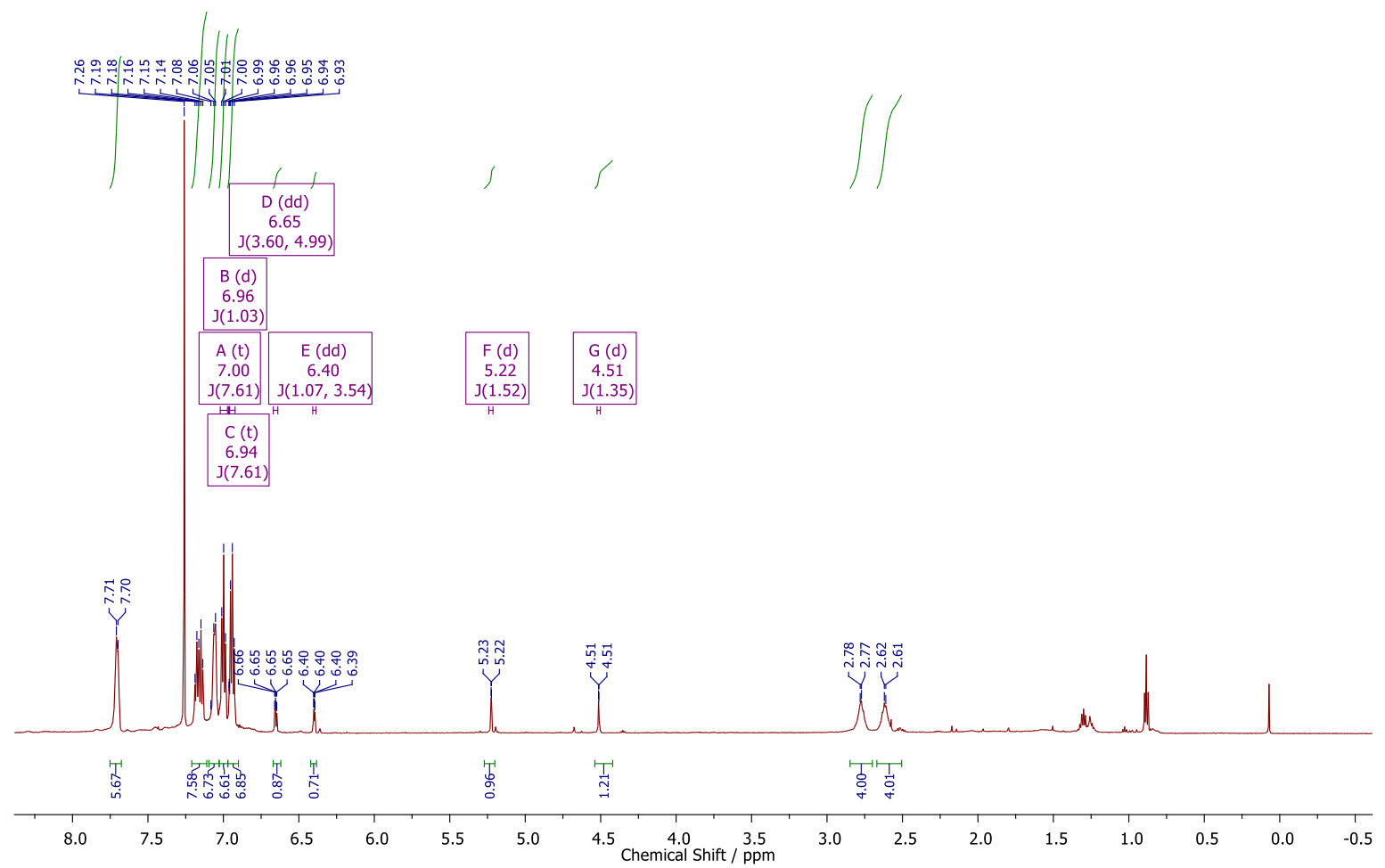

Figure S51. The ${ }^{1} \mathrm{H}$ NMR spectrum of $\mathbf{3 e}$. 

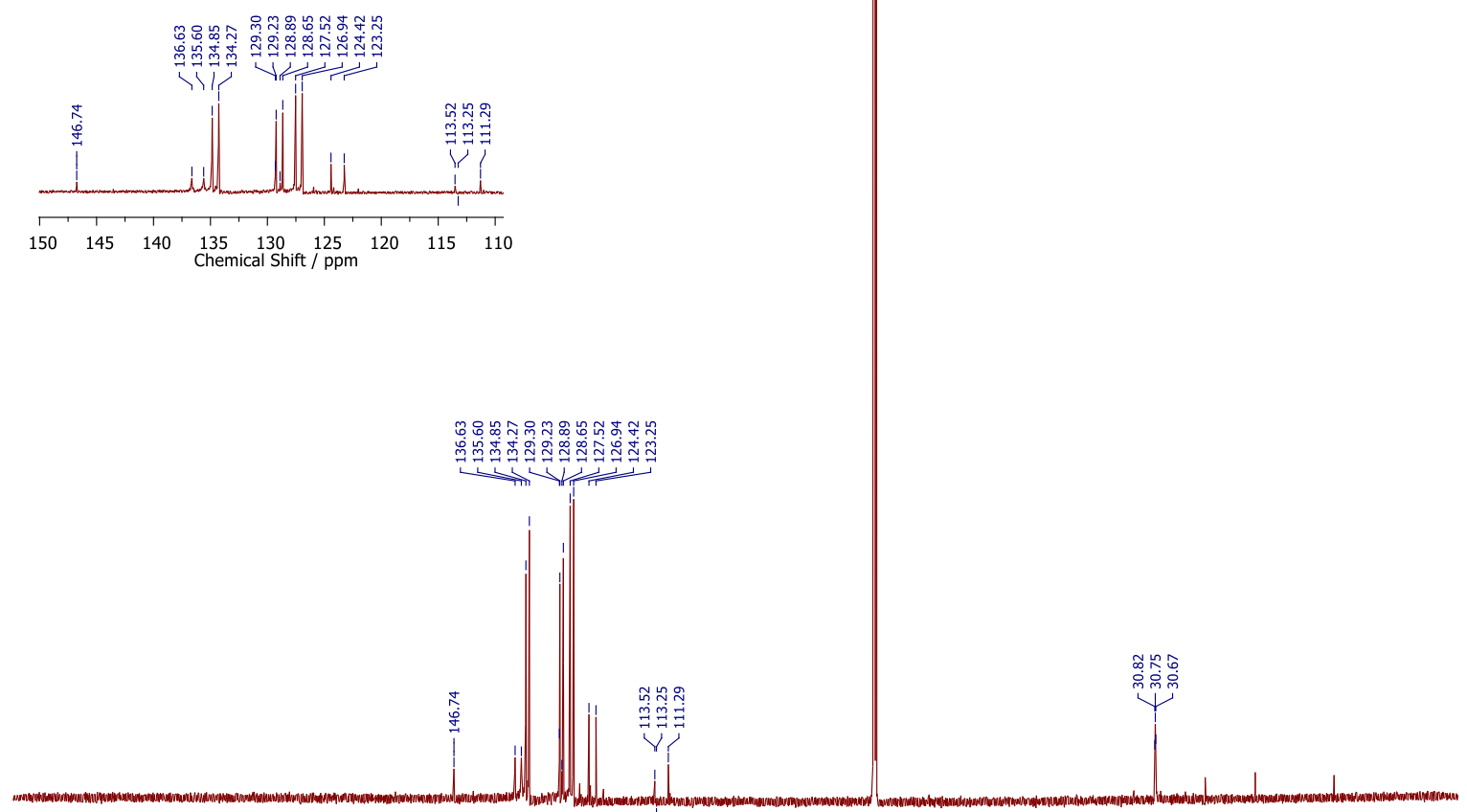

$\begin{array}{lllllllllllllllllllllllll}210 & 200 & 190 & 180 & 170 & 160 & 150 & 140 & 130 & 120 & 110 & 100 & 90 & 80 & 70 & 60 & 50 & 40 & 30 & 20 & 10 & 0 & -10\end{array}$

Figure S52. The ${ }^{13} \mathrm{C}\left\{{ }^{1} \mathrm{H}\right\}$ NMR spectrum of 3e. The inset shows an expansion of the aromatic carbon region for clarity. 


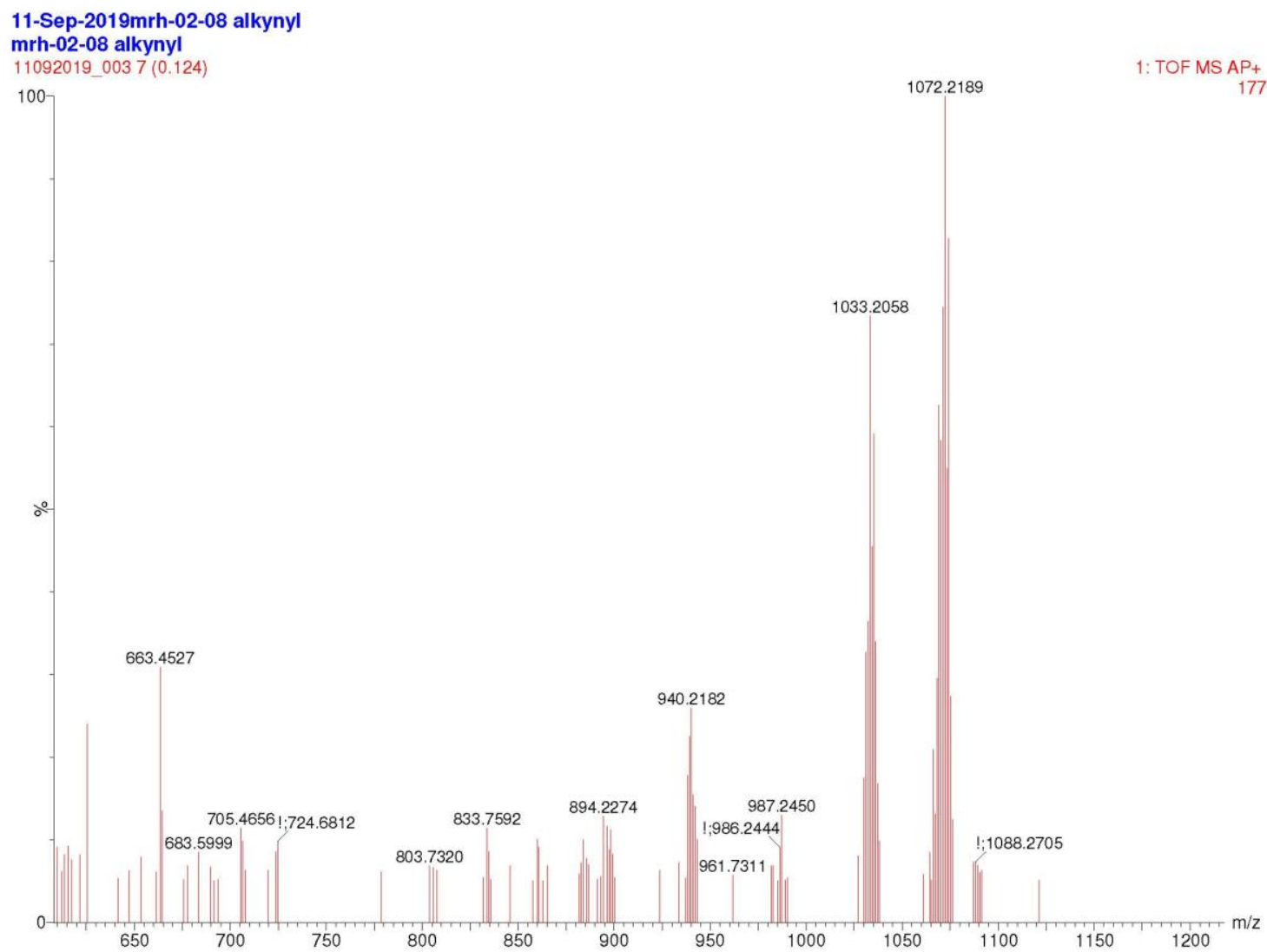

Figure S53. The APCI $(+)$ mass spectrum of $\mathbf{3 e}$. 


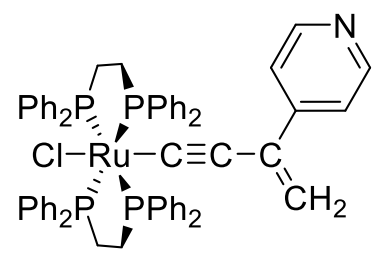

trans $-\left[\mathrm{Ru}\left\{\mathrm{C} \equiv \mathrm{CC}\left(=\mathrm{CH}_{2}\right)\left(4-{ }^{c} \mathrm{C}_{5} \mathrm{H}_{4} \mathrm{~N}\right)\right\} \mathrm{Cl}(\text { dppe })_{2}\right](\mathbf{3 f})$

MRH-02-90

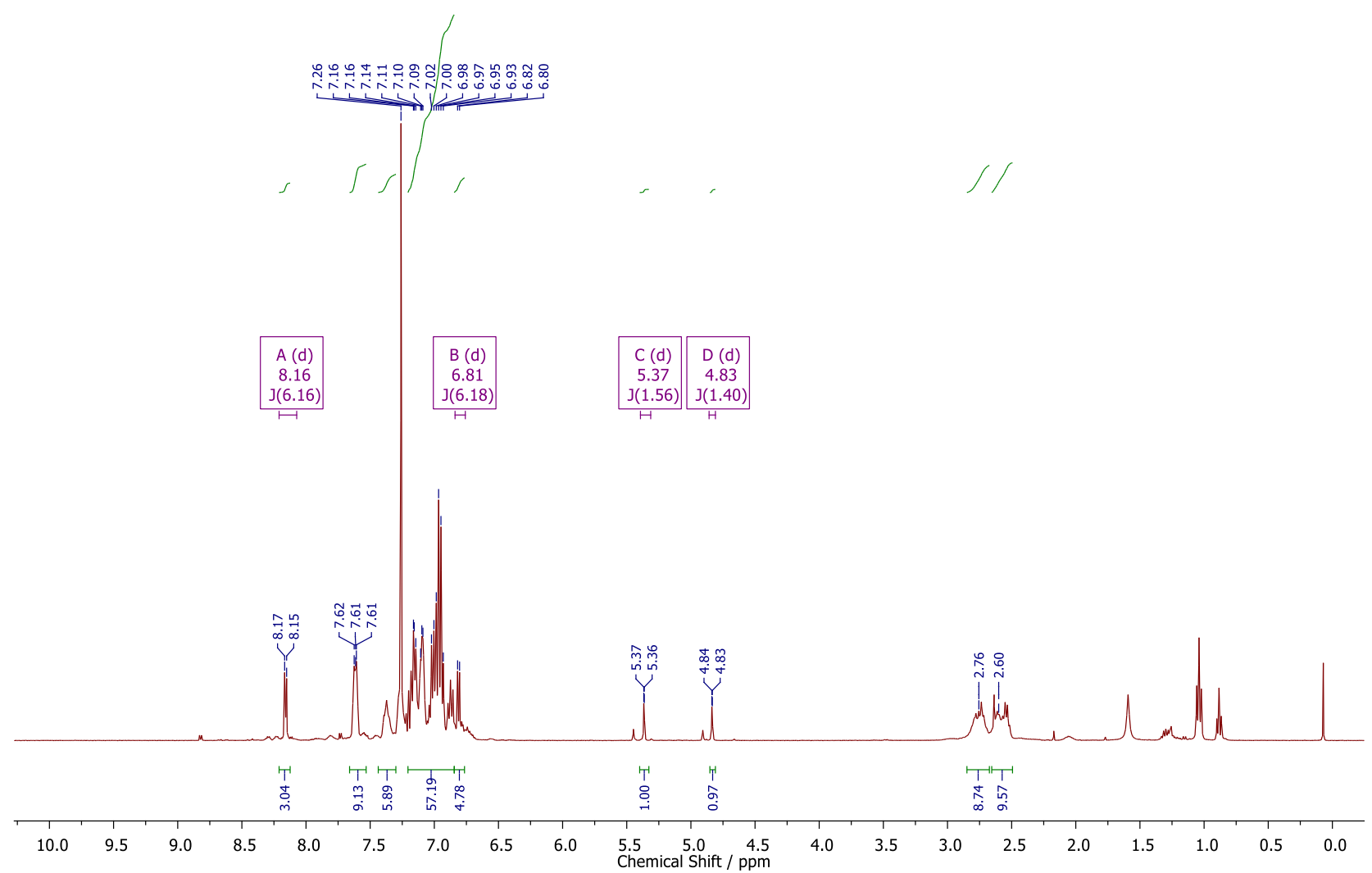

Figure S54. The ${ }^{1} \mathrm{H}$ NMR spectrum of $\mathbf{3 f}$. 

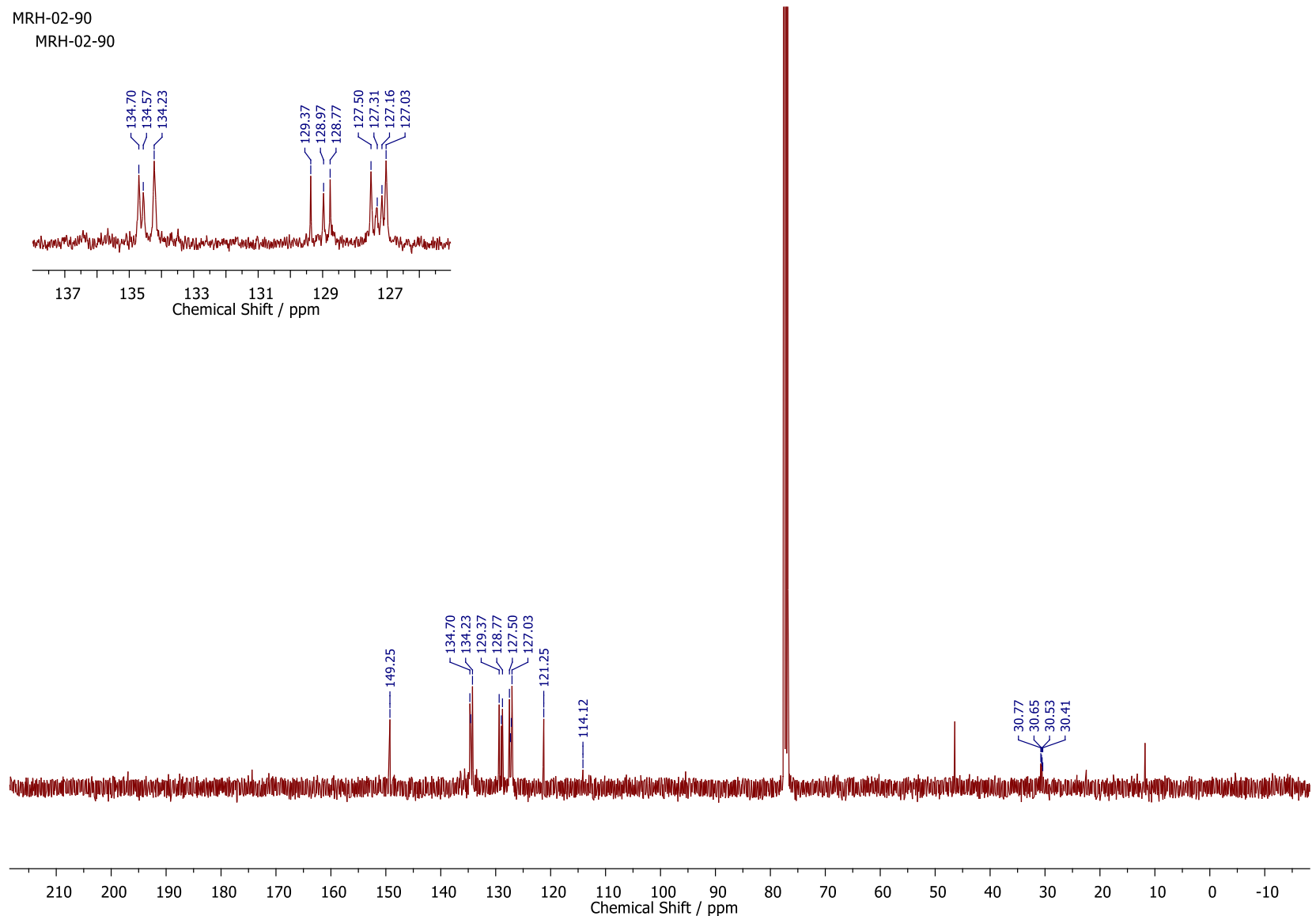

Figure S55. The ${ }^{13} \mathrm{C}\left\{{ }^{1} \mathrm{H}\right\}$ NMR spectrum of 3f. The inset shows an expansion of the aromatic carbon region for clarity. 


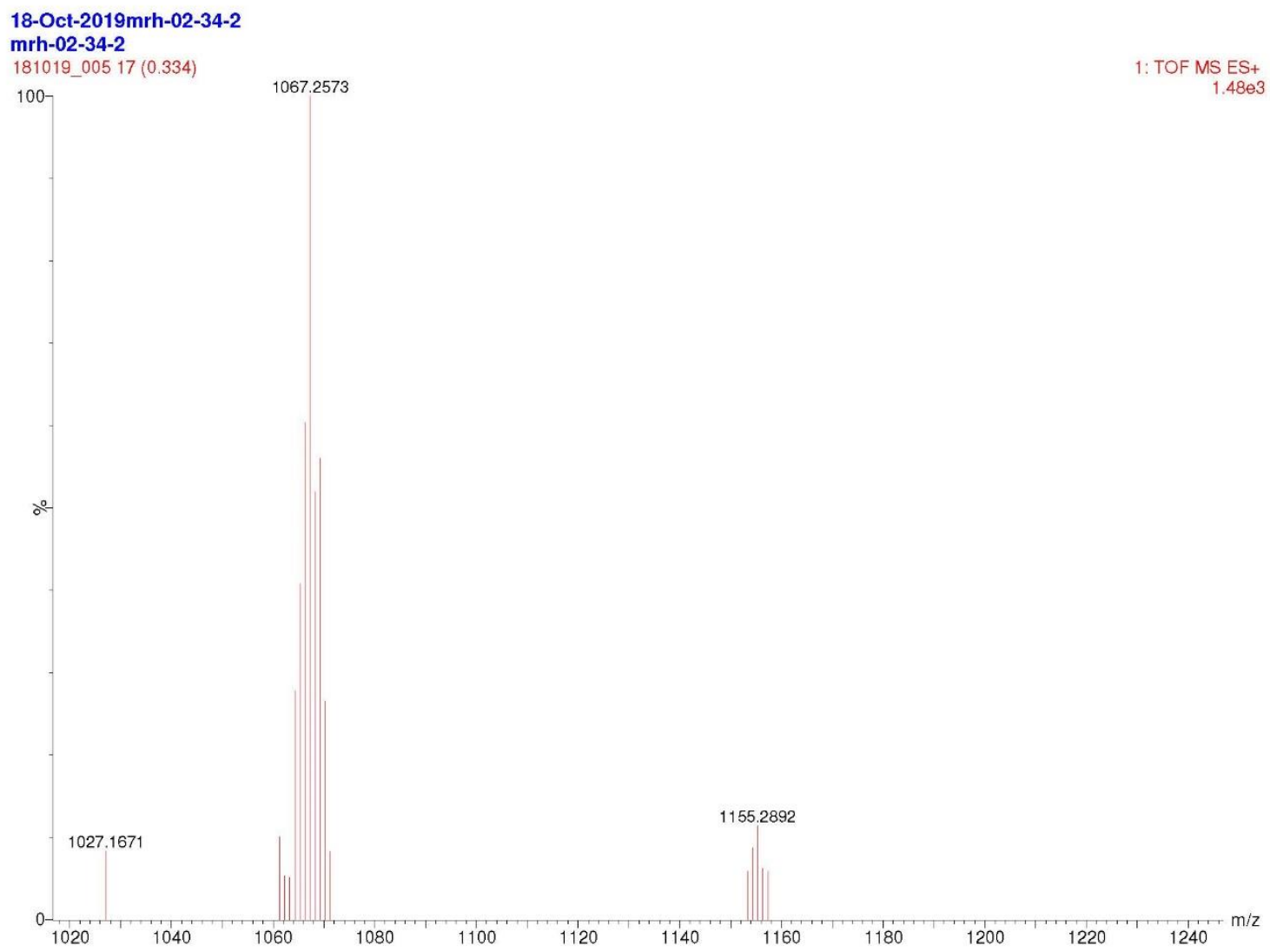

Figure S56. The ESI(+) mass spectrum of $\mathbf{3 f}$. 


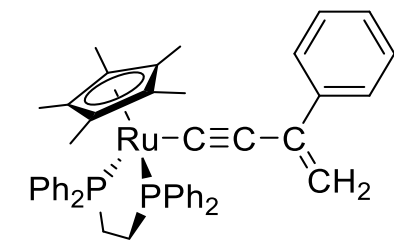

$\left[\mathrm{Ru}\left\{\mathrm{C} \equiv \mathrm{CC}\left(=\mathrm{CH}_{2}\right) \mathrm{Ph}\right\}(\mathrm{dppe}) \mathrm{Cp}^{*}\right](\mathbf{4 b})$

mrh-02-47_alkynyl_400_PROTON_cdcl3_20191108_001 mrh-02-47_alkynyl
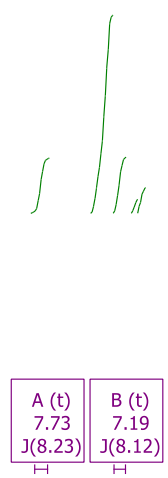

\begin{tabular}{|c|c|}
\hline$C(d)$ & $D(d)$ \\
5.25 & 4.66 \\
$J(1.90)$ & $J(1.66)$ \\
\hline
\end{tabular}

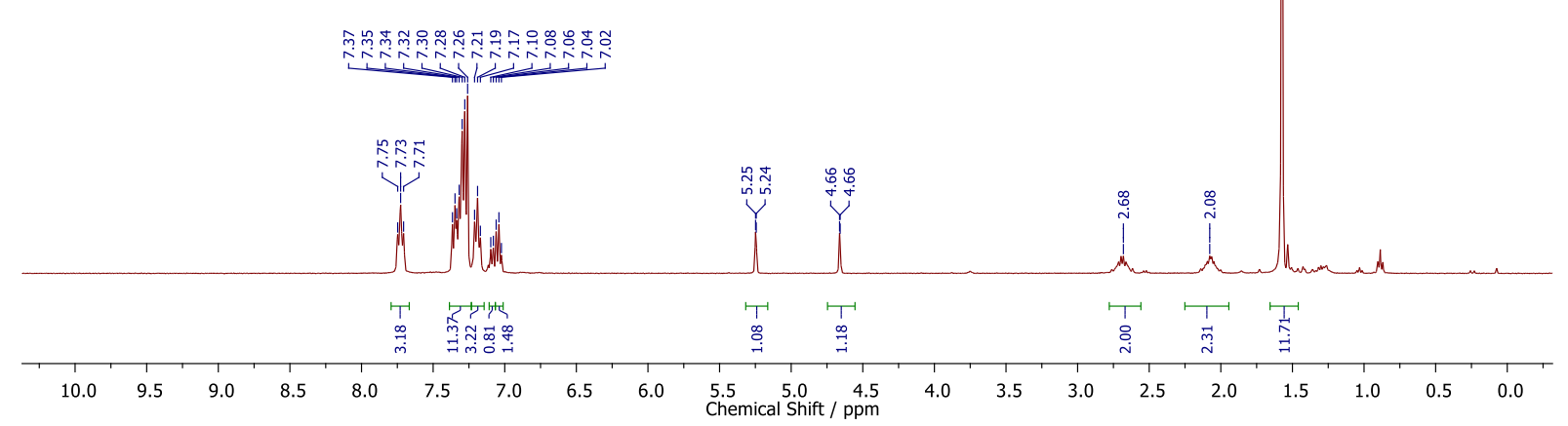

Figure S57. The ${ }^{1} \mathrm{H}$ NMR spectrum of $\mathbf{4 b}$. 
mrh-02-47_alkynyl_400_CARBON_cdcl3_20191108_001 mrh-02-47_alkynyl

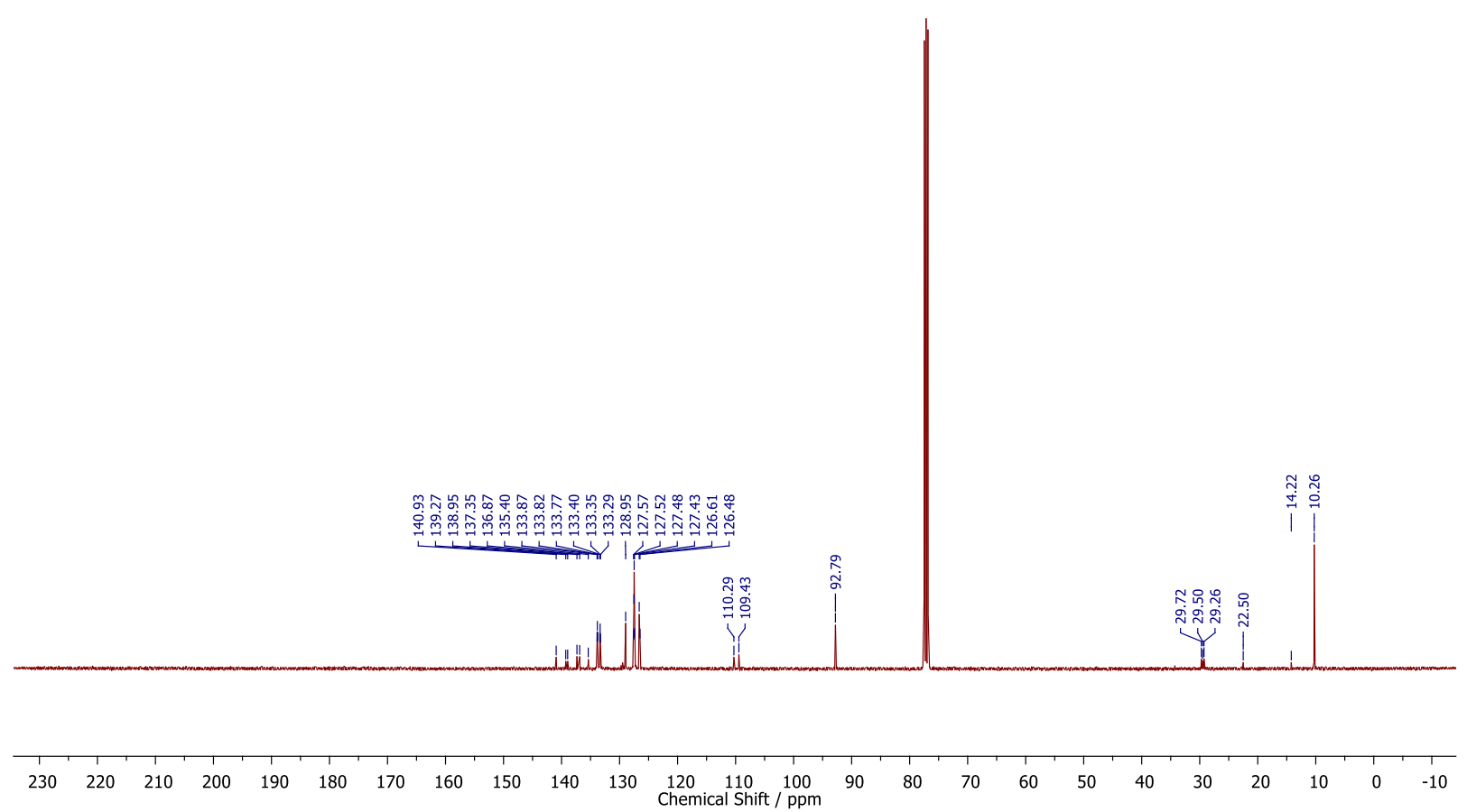

Figure S58. The ${ }^{13} \mathrm{C}\left\{{ }^{1} \mathrm{H}\right\}$ NMR spectrum of $\mathbf{4 b}$. 


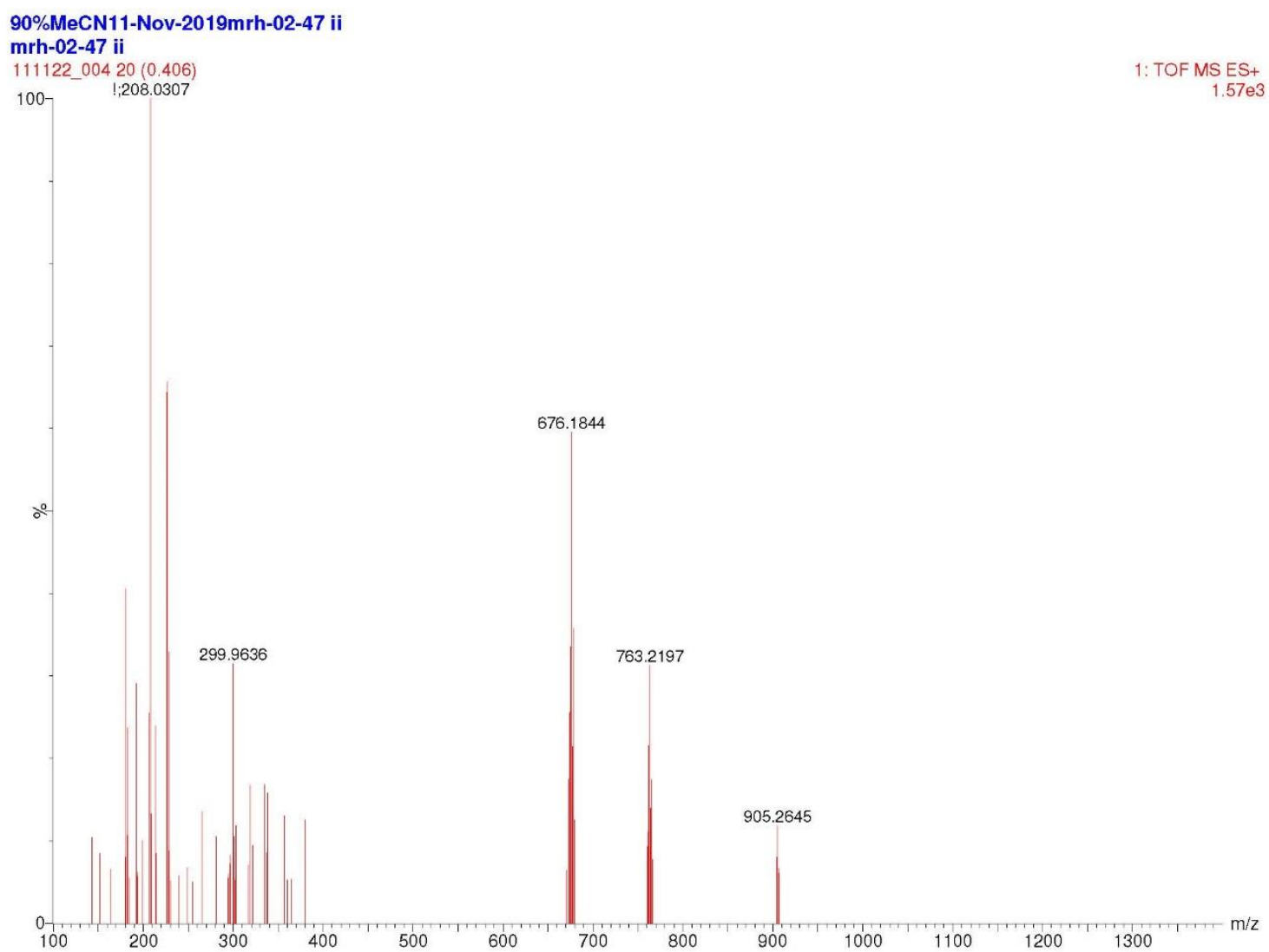

Figure S59. The ESI(+) mass spectrum of $\mathbf{4 b}$. 


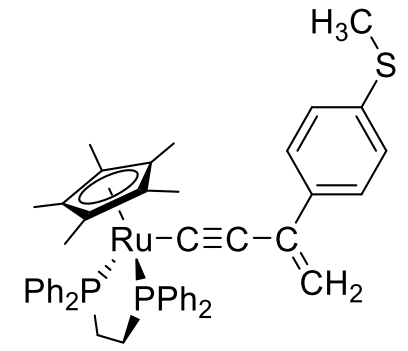

$\left[\mathrm{Ru}\left\{\mathrm{C} \equiv \mathrm{CC}\left(=\mathrm{CH}_{2}\right)\left(4-\mathrm{MeS}_{-} \mathrm{C}_{6} \mathrm{H}_{4}\right)\right\}(\mathrm{dppe}) \mathrm{Cp}^{*}\right](\mathbf{4 d})$

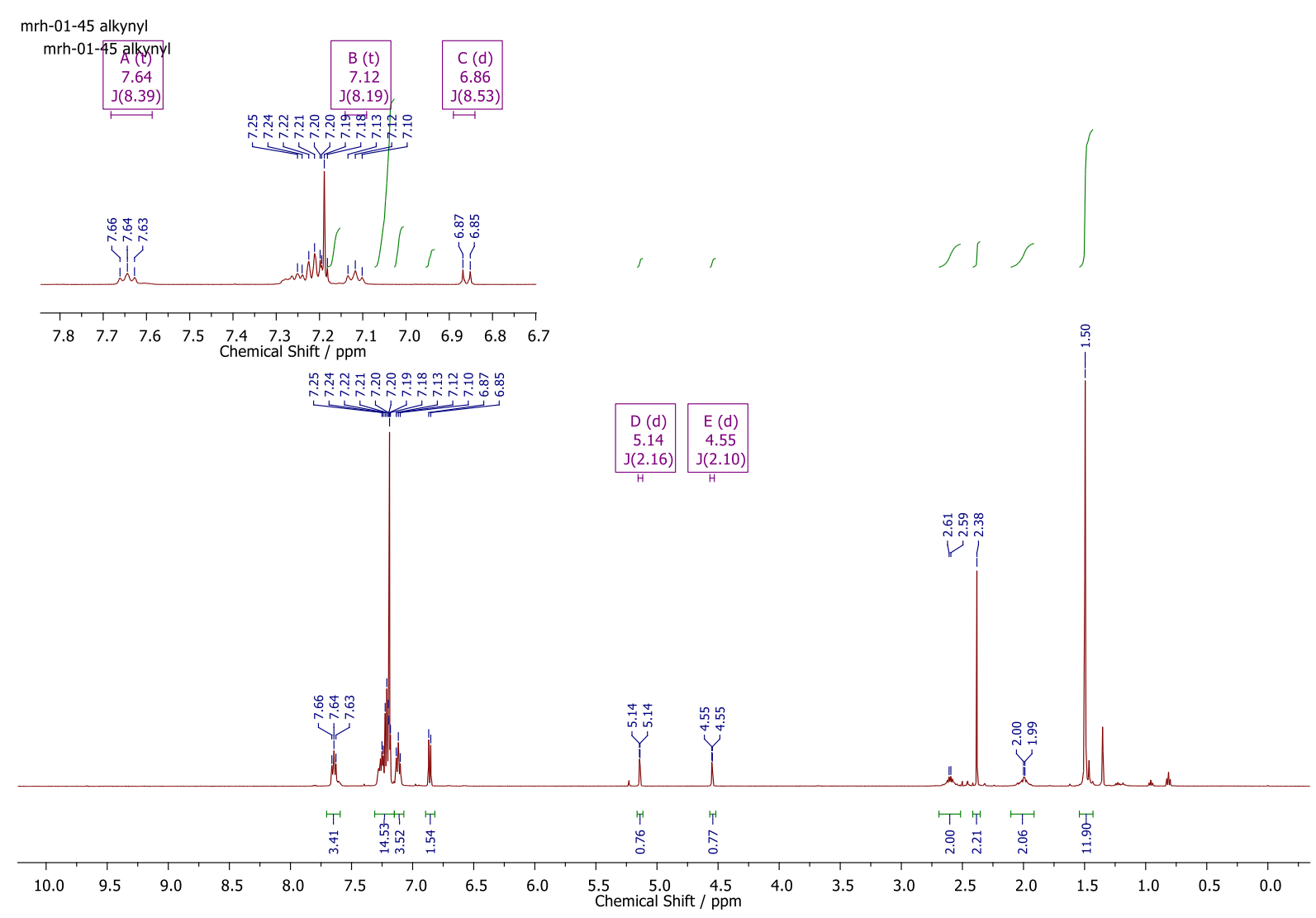

Figure S60. The ${ }^{1} \mathrm{H}$ NMR spectrum of $\mathbf{4 d}$. The inset shows an expansion of the aromatic region for clarity. 


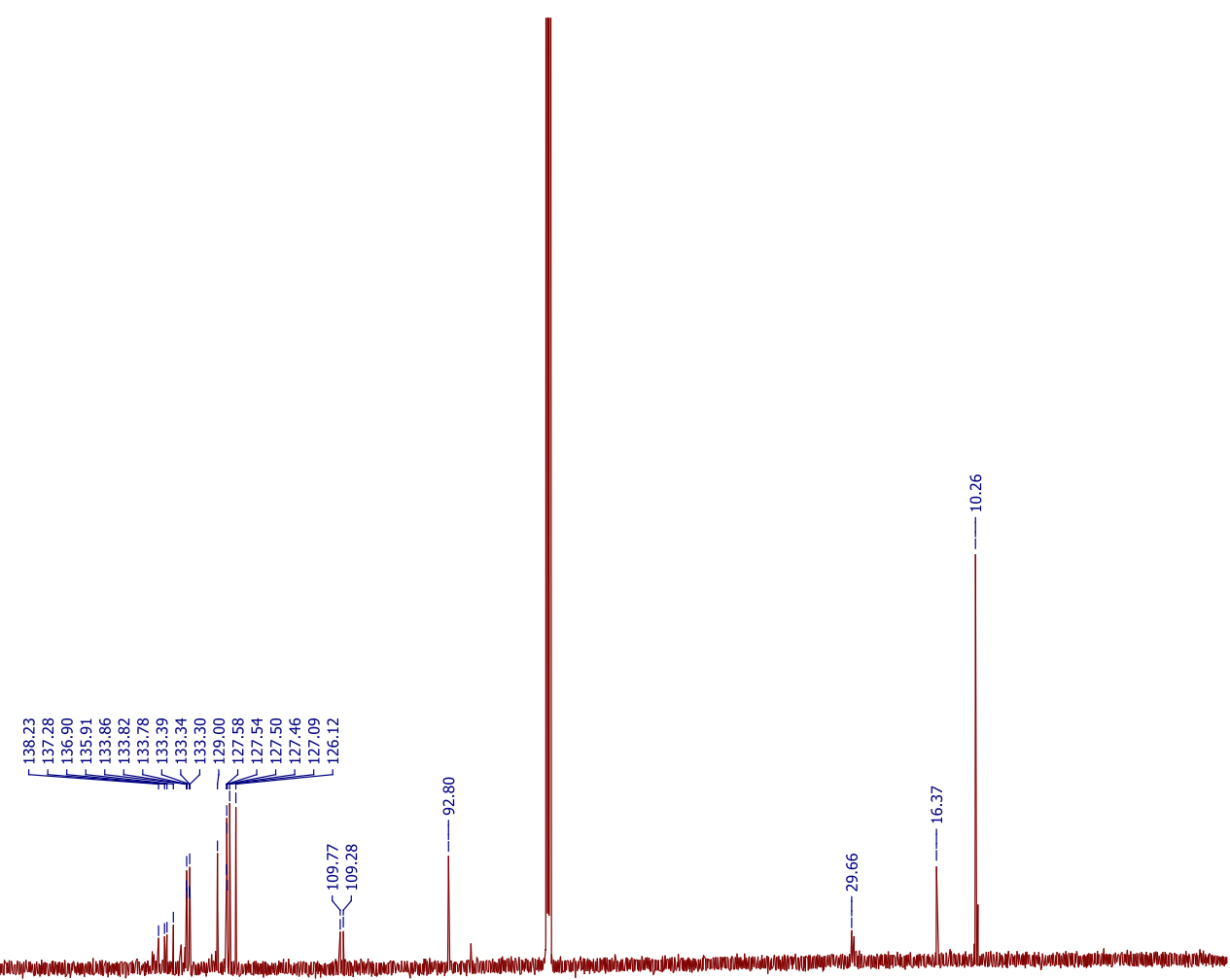

$\begin{array}{lllllllllllllllllllllllllll}210 & 200 & 190 & 180 & 170 & 160 & 150 & 140 & 130 & 120 & 110 & 100 & 90 & 80 & 70 & 60 & 50 & 40 & 30 & 20 & 10 & 0 & -10 & -20\end{array}$

Figure S61. The ${ }^{13} \mathrm{C}\left\{{ }^{1} \mathrm{H}\right\}$ NMR spectrum of $\mathbf{4 d}$. 


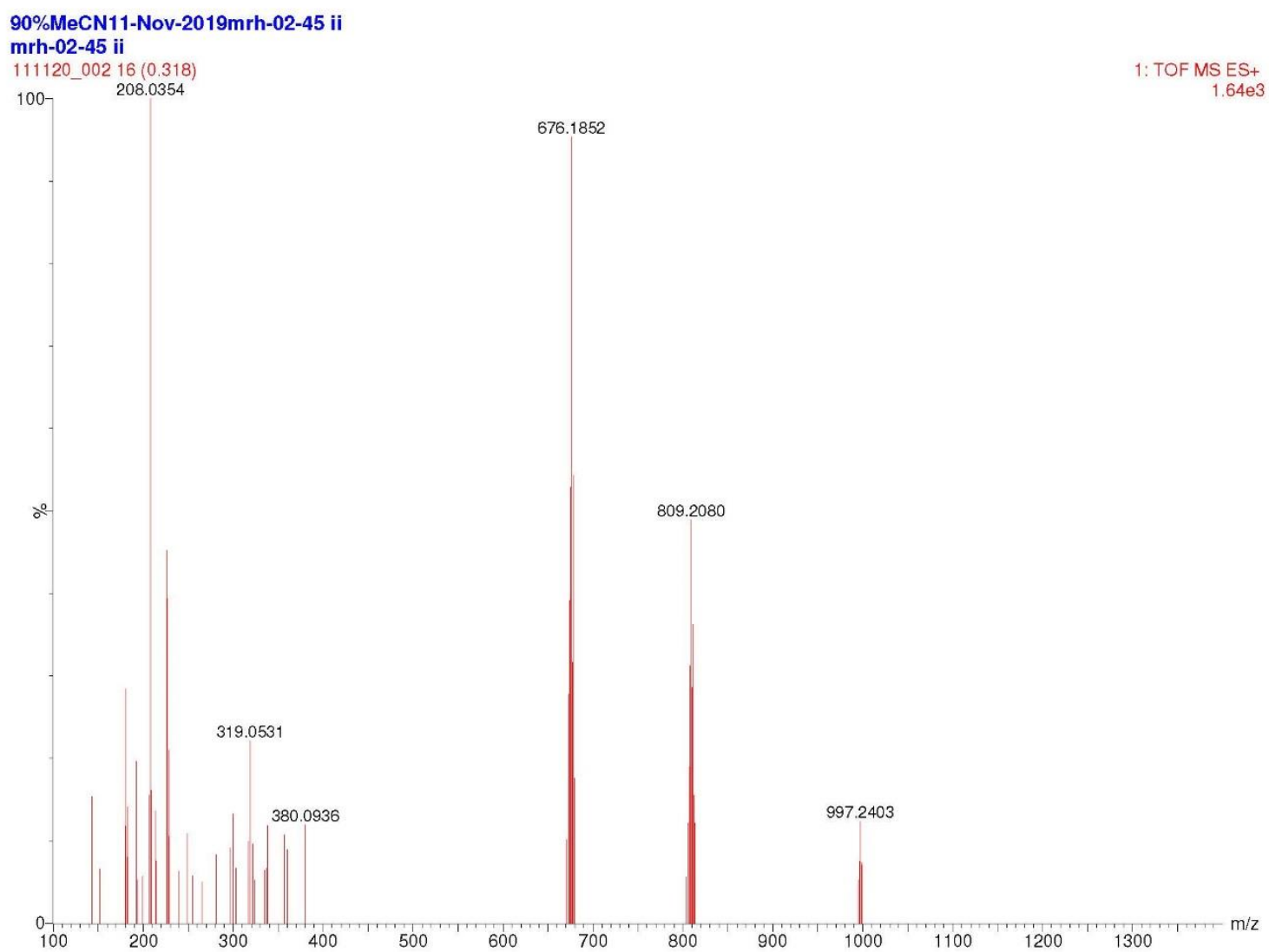

Figure S62. The ESI(+) mass spectrum of $\mathbf{4 d}$. 
Tritylium Addition Products

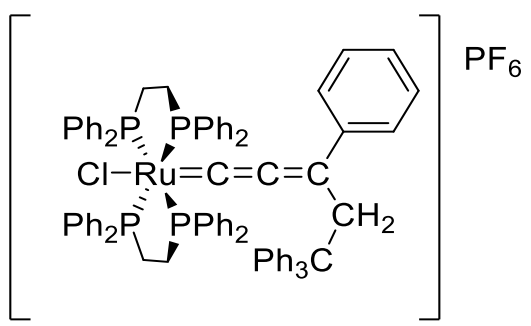

trans $-\left[\mathrm{Ru}\left\{\mathrm{C}=\mathrm{C}=\mathrm{C}\left(\mathrm{CH}_{2} \mathrm{CPh}_{3}\right) \mathrm{Ph}\right\} \mathrm{Cl}(\mathrm{dppe})_{2}\right] \mathrm{BF}_{4}\left([\mathbf{5 b}] \mathrm{BF}_{4}\right)$

mrh-02-32_400_PROTON_cdcl3_20191115_001 mrh-02-32

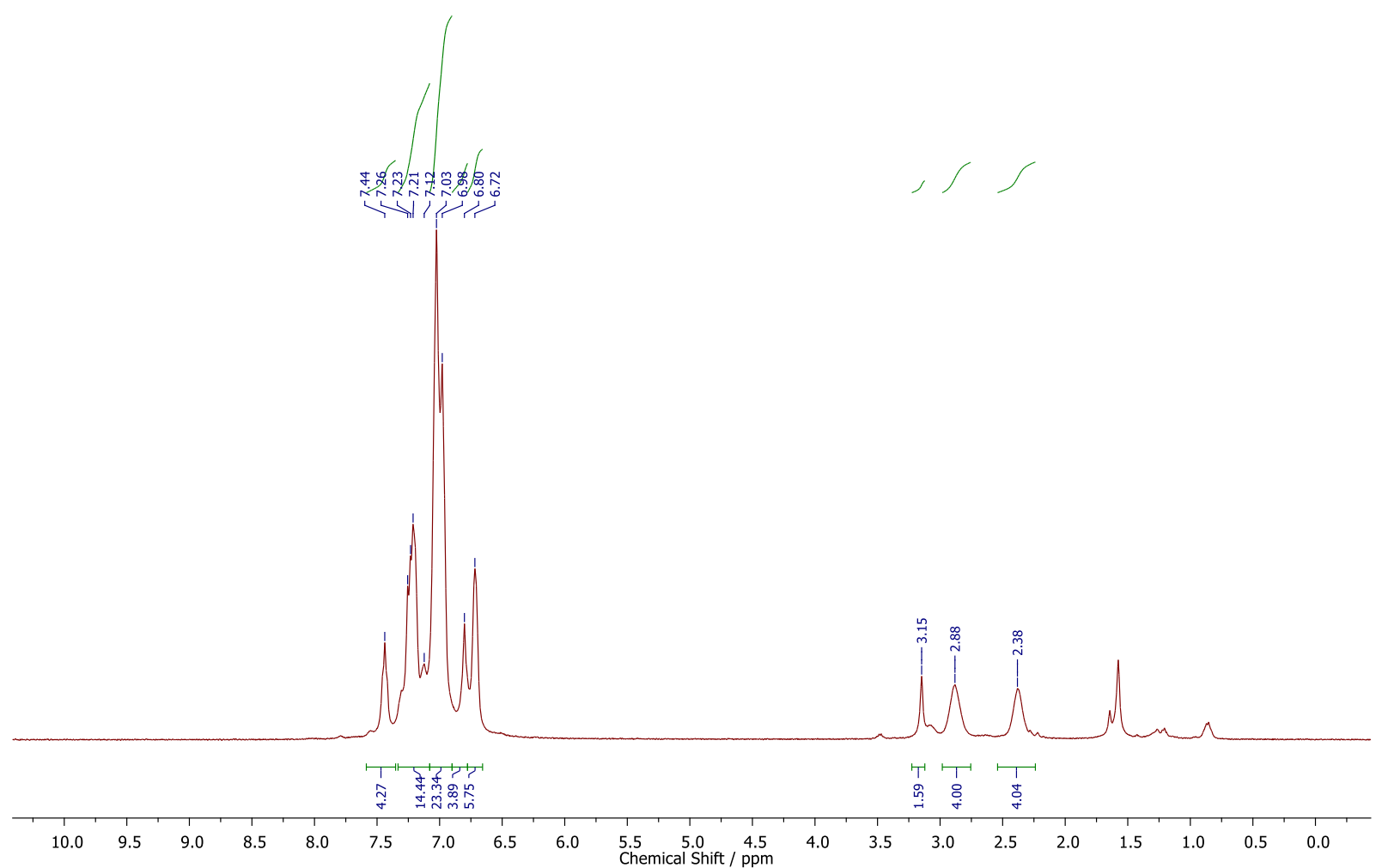

Figure S63. The ${ }^{1} \mathrm{H}$ NMR spectrum of $[\mathbf{5 b}] \mathrm{BF}_{4}$. 
mrh-02-32_400_CARBON_Cdcl3_20191116_001 mrh-02-32

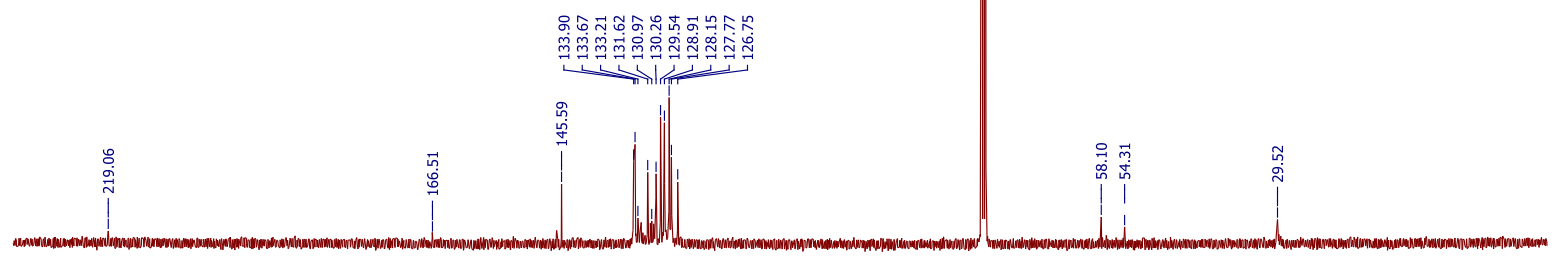

$\begin{array}{lllllllllllllllllllllllll}230 & 220 & 210 & 200 & 190 & 180 & 170 & 160 & 150 & 140 & 130 & \begin{array}{c}120 \\ \text { Chemical Shift } / \mathrm{ppm}\end{array} & 90 & 80 & 70 & 60 & 50 & 40 & 30 & 20 & 10 & 0 & -10\end{array}$

Figure S64. The ${ }^{13} \mathrm{C}\left\{{ }^{1} \mathrm{H}\right\}$ NMR spectrum of $[5 \mathbf{b}] \mathrm{BF}_{4}$. 
mrh-02-32_400_CARBON_cdcl3_20191115_001

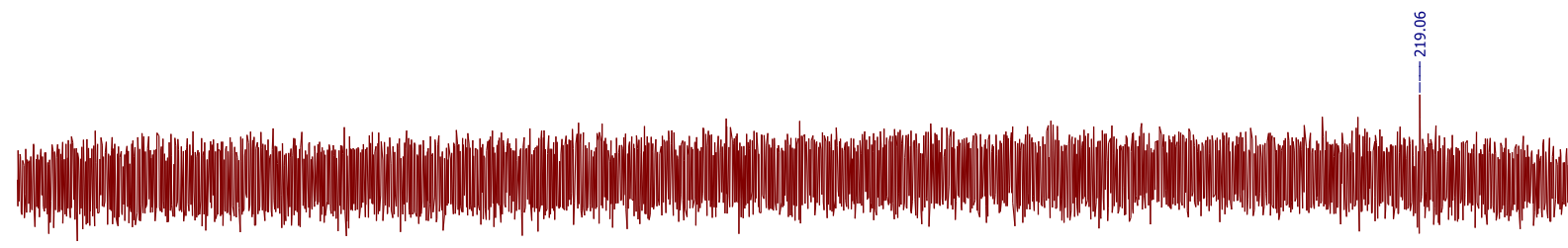

\begin{tabular}{rllllllllllllllllllllll}
\hline & 400 & 390 & 380 & 370 & 360 & 350 & 340 & 330 & 320 & 310 & 300 & 290 & 280 & 270 & 260 & 250 & 240 & 230 & 220 & 210 & 200
\end{tabular}

Figure S65. An expansion of the ${ }^{13} \mathrm{C}\left\{{ }^{1} \mathrm{H}\right\}$ NMR spectrum of $[\mathbf{5 b}] \mathrm{BF}_{4}$, showing the allenylidene resonance $C(\beta)$. 


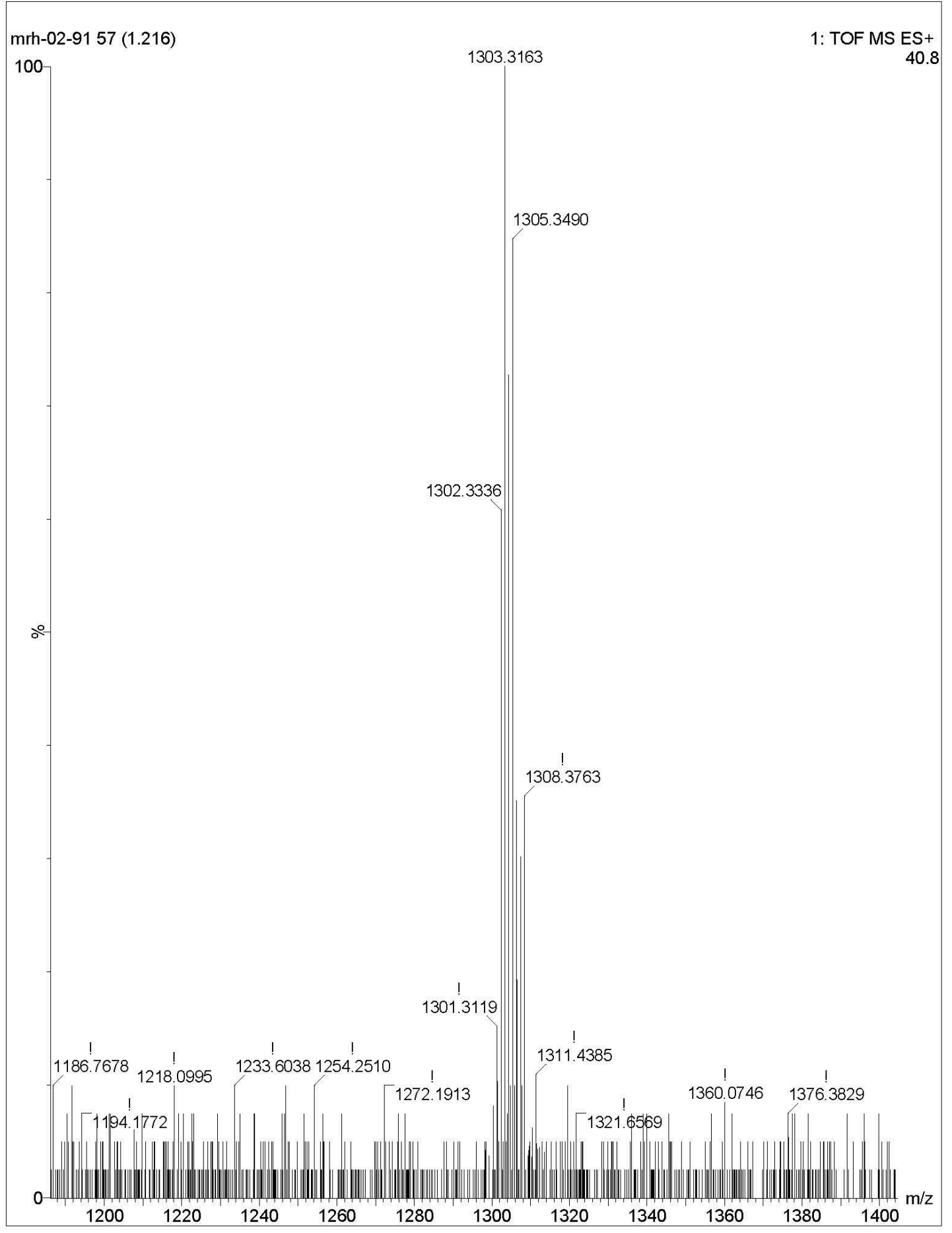

Figure S66. The ESI $(+)$ mass spectrum of $[\mathbf{5 b}] \mathrm{BF}_{4}$. 


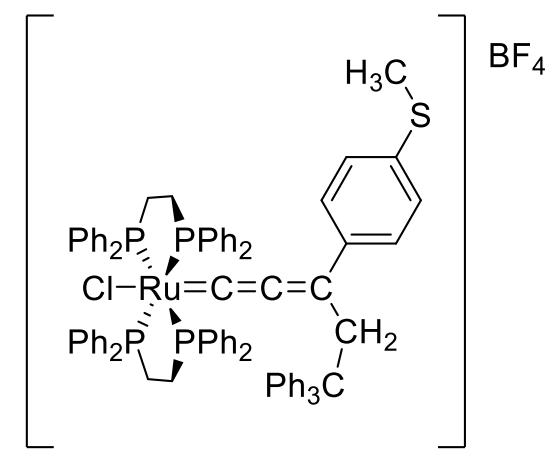

trans $-\left[\mathrm{Ru}\left\{\mathrm{C}=\mathrm{C}=\mathrm{C}\left(\mathrm{CH}_{2} \mathrm{CPh}_{3}\right)\left(4-\mathrm{MeS}-\mathrm{C}_{6} \mathrm{H}_{4}\right)\right\} \mathrm{Cl}(\mathrm{dppe})_{2}\right] \mathrm{BF}_{4}\left([\mathbf{5 d}] \mathrm{BF}_{4}\right)$

MRH-02-82
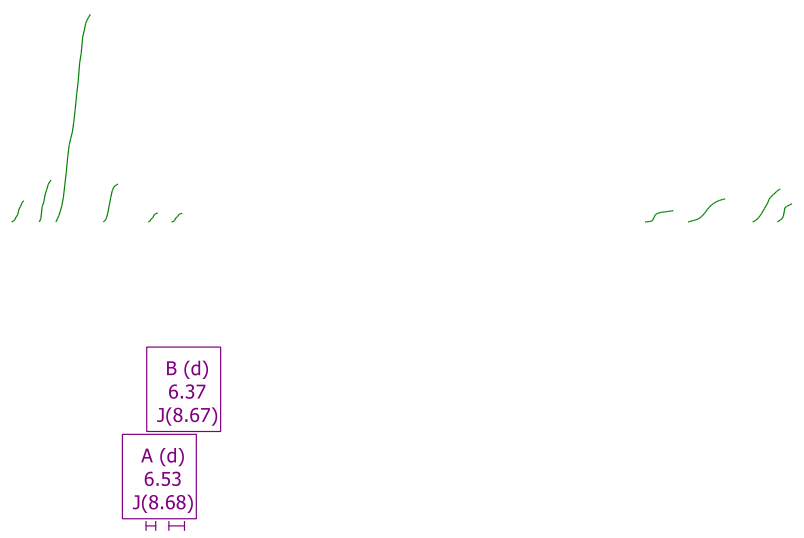

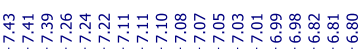

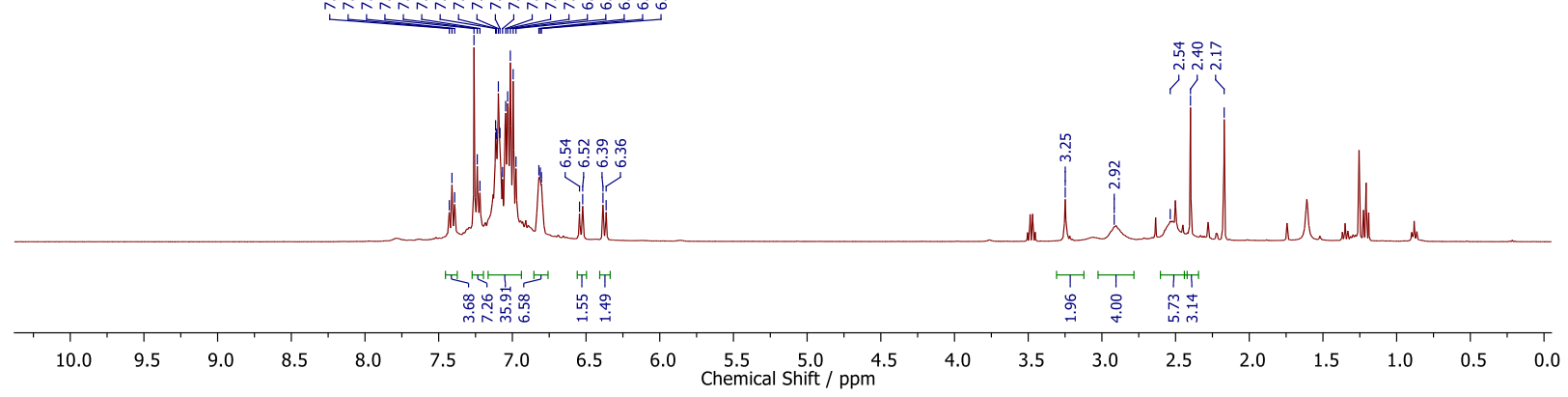

Figure S67. The ${ }^{1} \mathrm{H}$ NMR spectrum of $[\mathbf{5 d}] \mathrm{BF}_{4}$. 

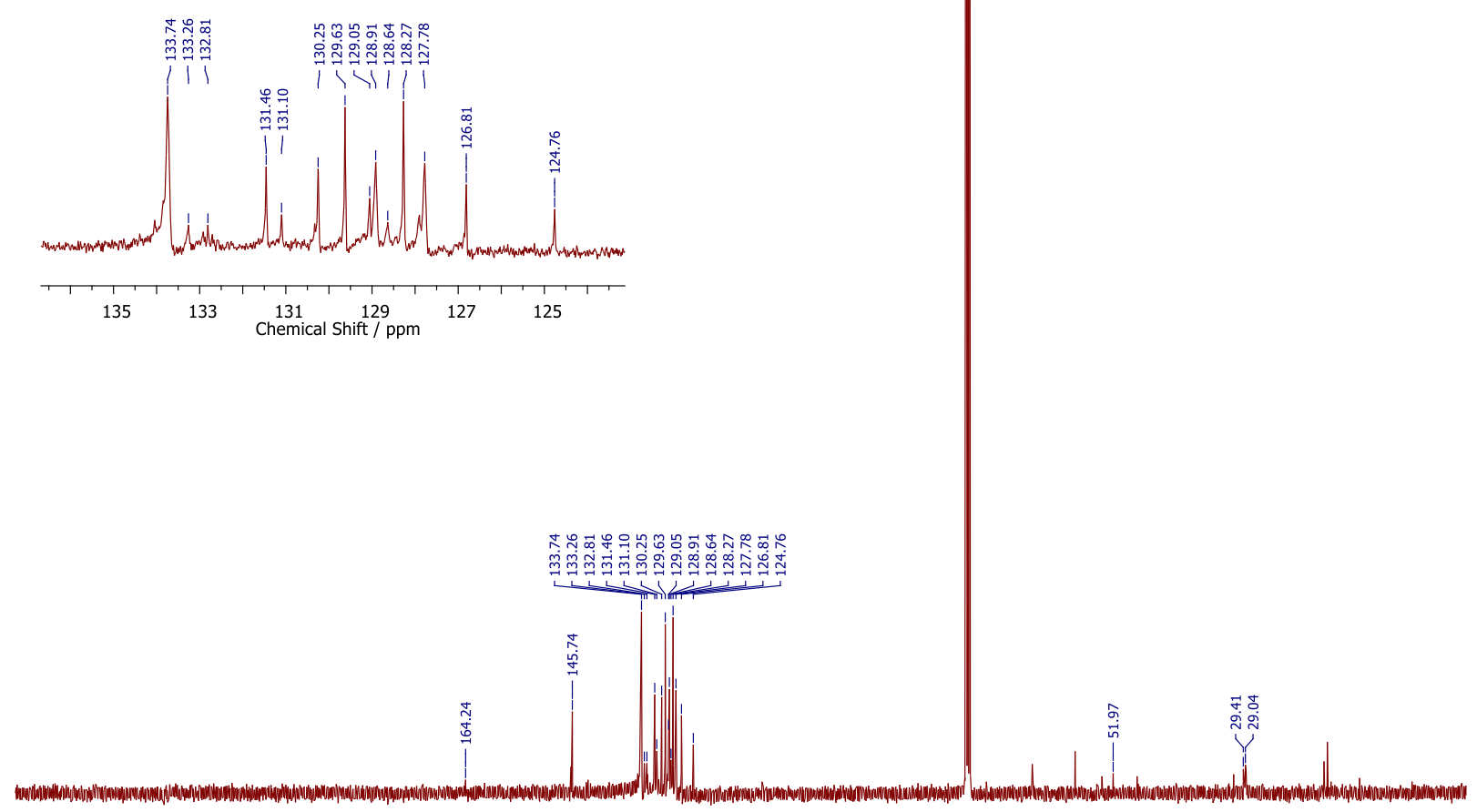

$\begin{array}{lllllllllllllllllllllllllllll}240 & 230 & 220 & 210 & 200 & 190 & 180 & 170 & 160 & 150 & 140 & 130 & 120 & 110 & 100 & 90 & 80 & 70 & 60 & 50 & 40 & 30 & 20 & 10 & 0 & 0\end{array}$

Figure S68. The ${ }^{13} \mathrm{C}\left\{{ }^{1} \mathrm{H}\right\}$ NMR spectrum of $[\mathbf{5 d}] \mathrm{BF}_{4}$. 


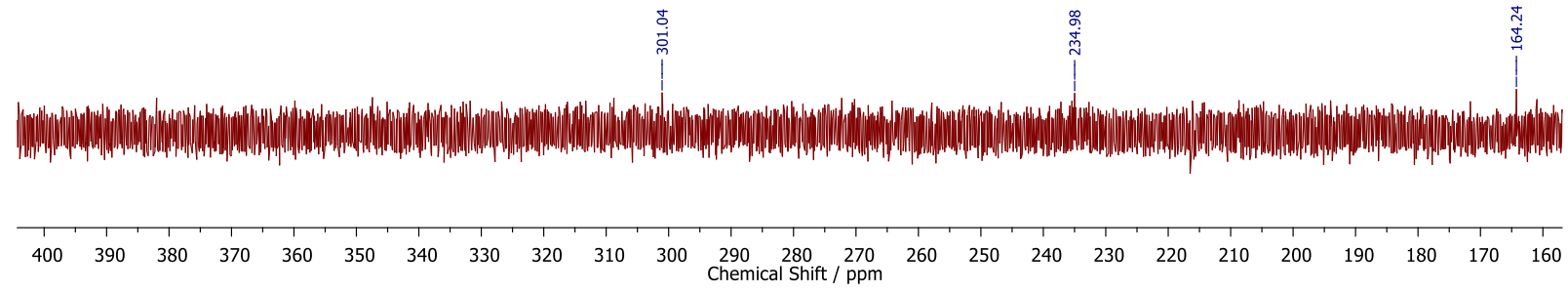

Figure S69. An expansion of the ${ }^{13} \mathrm{C}\left\{{ }^{1} \mathrm{H}\right\}$ NMR spectrum of $[\mathbf{5 d}] \mathrm{BF}_{4}$, showing the allenylidene resonances $C(\alpha), C(\beta)$ and $C(\gamma)$. 


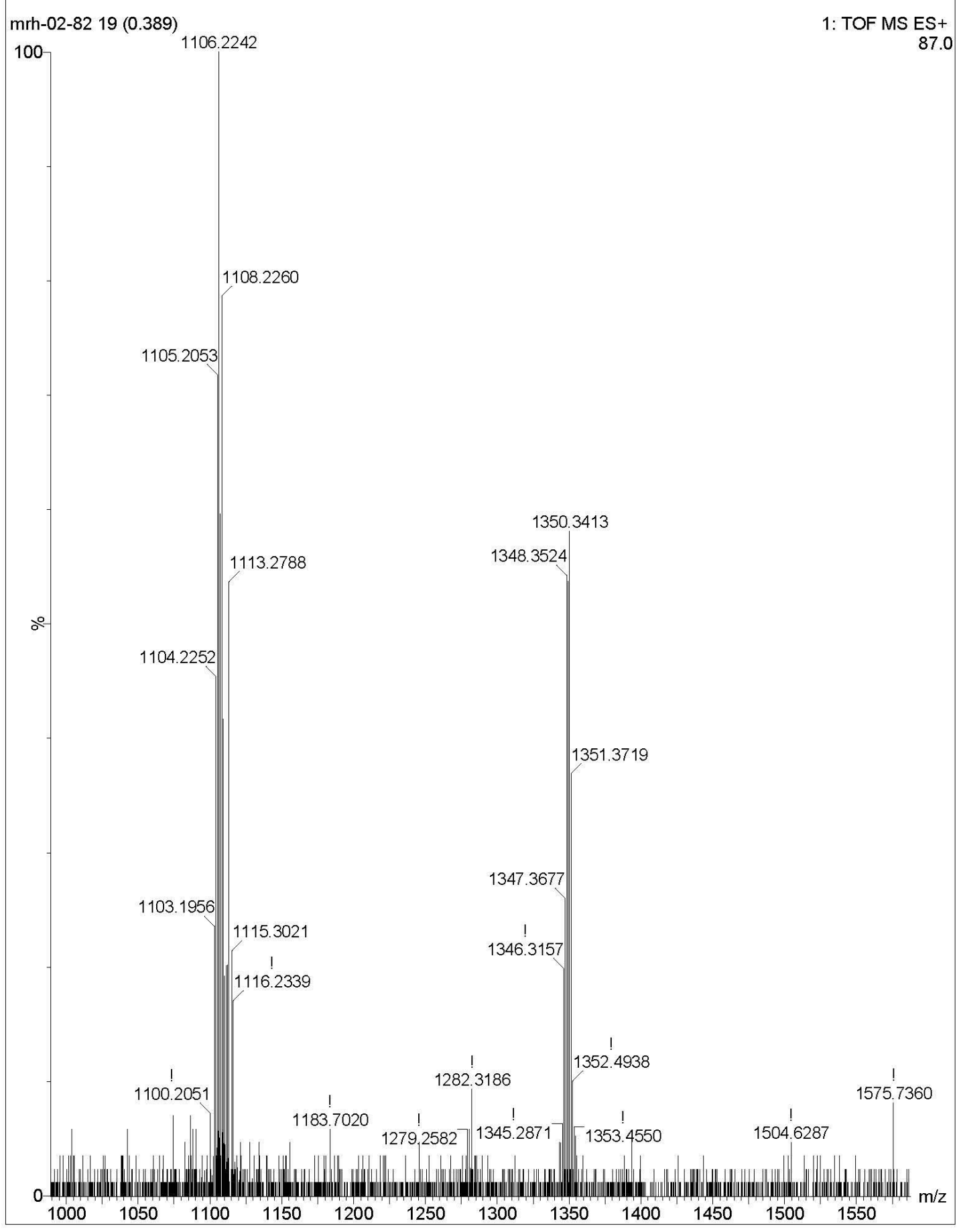

Figure S70. The ESI $(+)$ mass spectrum of $[\mathbf{5 d}] \mathrm{BF}_{4}$. 


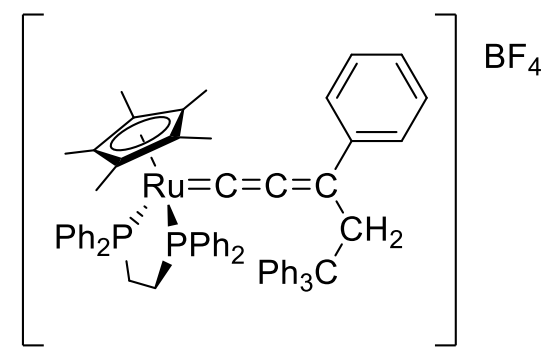

$\left[\mathrm{Ru}\left\{\mathrm{C}=\mathrm{C}=\mathrm{C}\left(\mathrm{CH}_{2} \mathrm{CPh}_{3}\right) \mathrm{Ph}\right\}(\mathrm{dppe}) \mathrm{Cp}^{*}\right] \mathrm{BF}_{4}\left([\mathbf{6 b}] \mathrm{BF}_{4}\right)$

mrh-02-75_f2_400_PROTON_cdcl3_20200304_001 mrh-02-75_f2

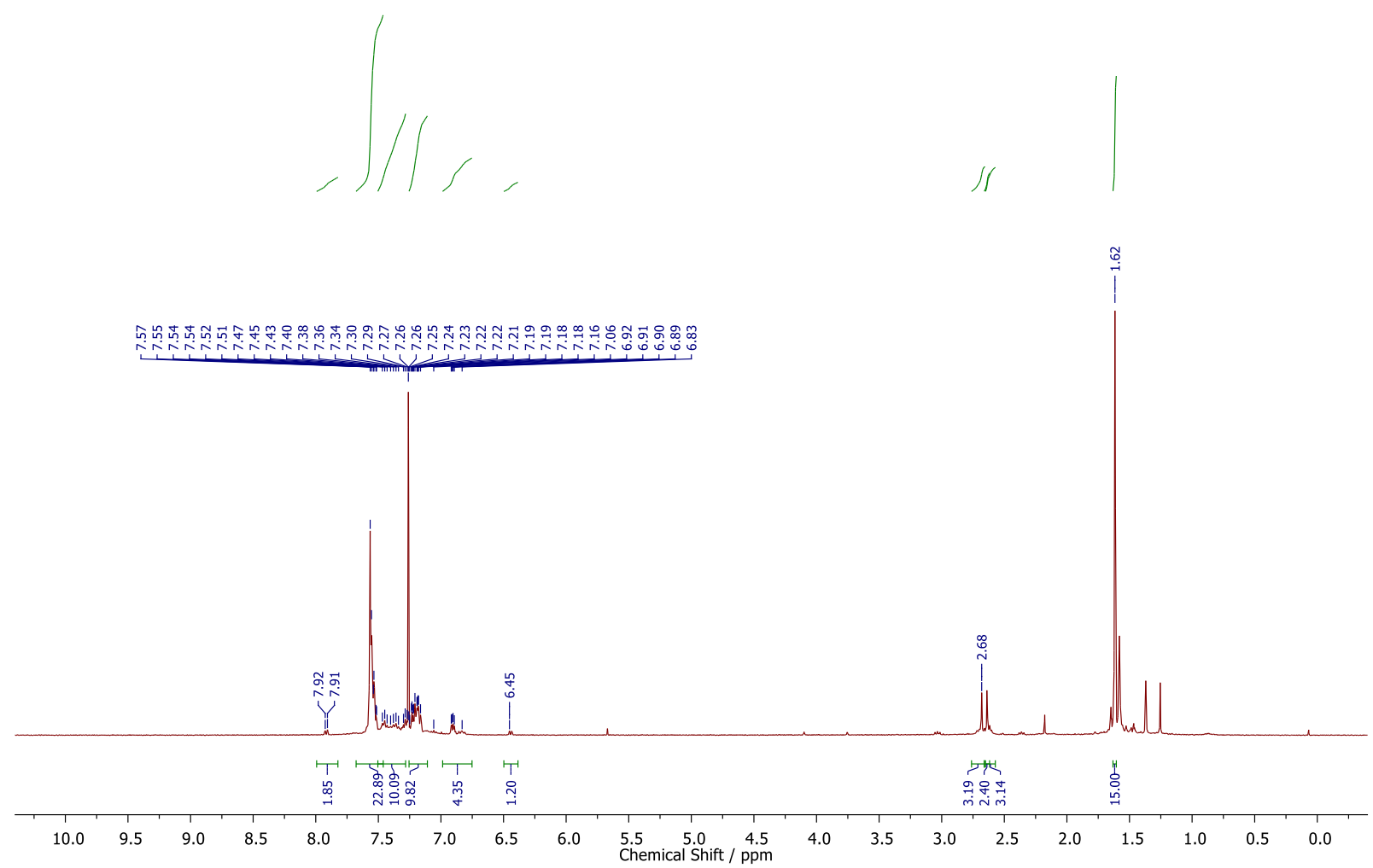

Figure S71. The ${ }^{1} \mathrm{H}$ NMR spectrum of $[\mathbf{6 b}] \mathrm{BF}_{4}$. 


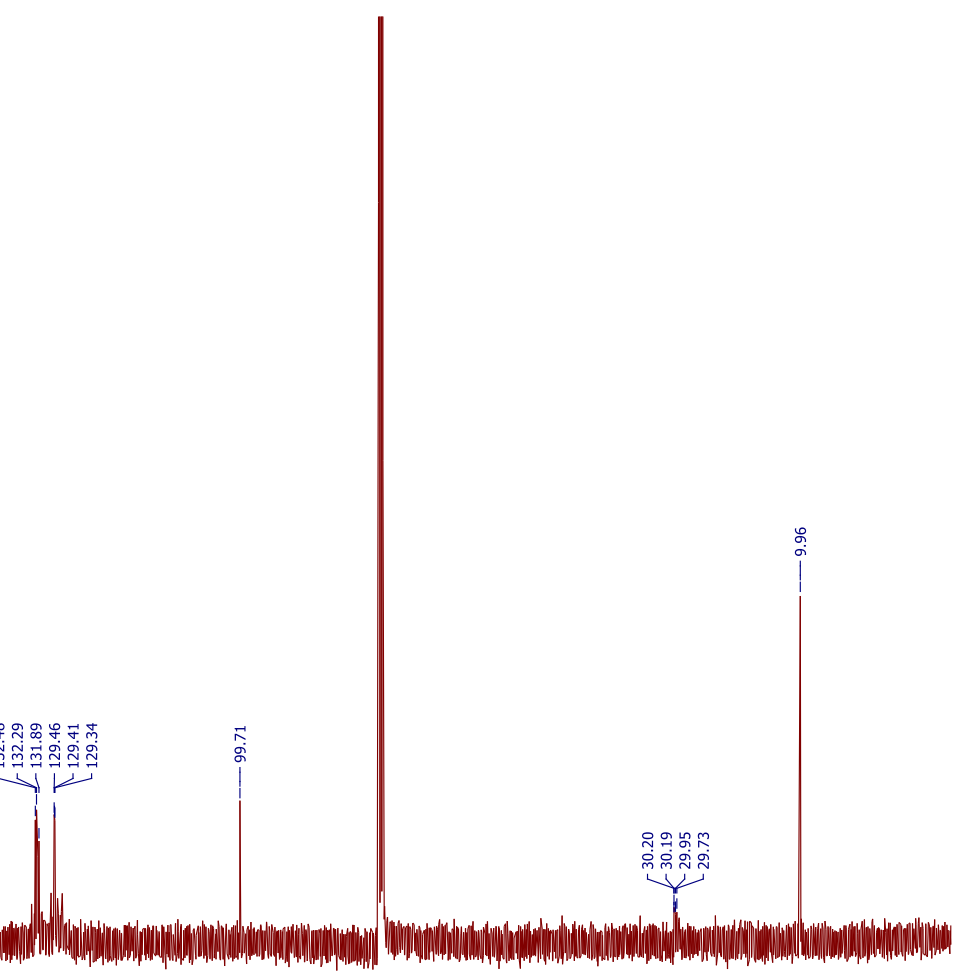

$\begin{array}{llllllllllllllllllllllllllllllllllll}230 & 220 & 210 & 200 & 190 & 180 & 170 & 160 & 150 & 140 & 130 & 120 & 110 & 100 & 90 & 80 & 70 & 60 & 50 & 40 & 30 & 20 & 10 & 0 & -10\end{array}$

Figure S72. The ${ }^{13} \mathrm{C}\left\{{ }^{1} \mathrm{H}\right\}$ NMR spectrum of $[6 \mathbf{b}] \mathrm{BF}_{4}$. 


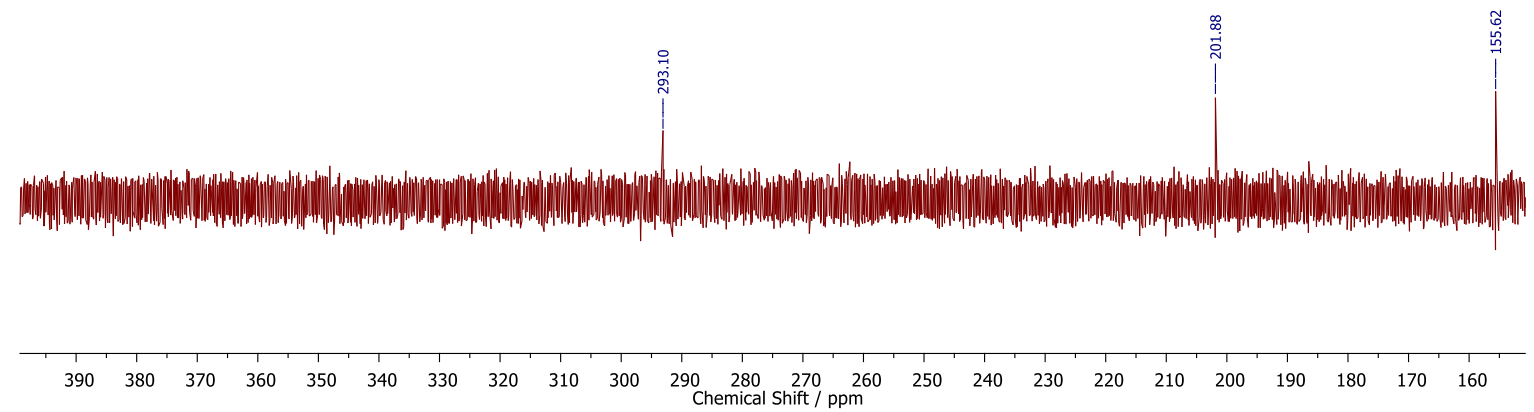

Figure S73. An expansion of the ${ }^{13} \mathrm{C}\left\{{ }^{1} \mathrm{H}\right\}$ NMR spectrum of $[\mathbf{6 b}] \mathrm{BF}_{4}$, showing the allenylidene resonances $C(\alpha), C(\beta)$ and $C(\gamma)$. 


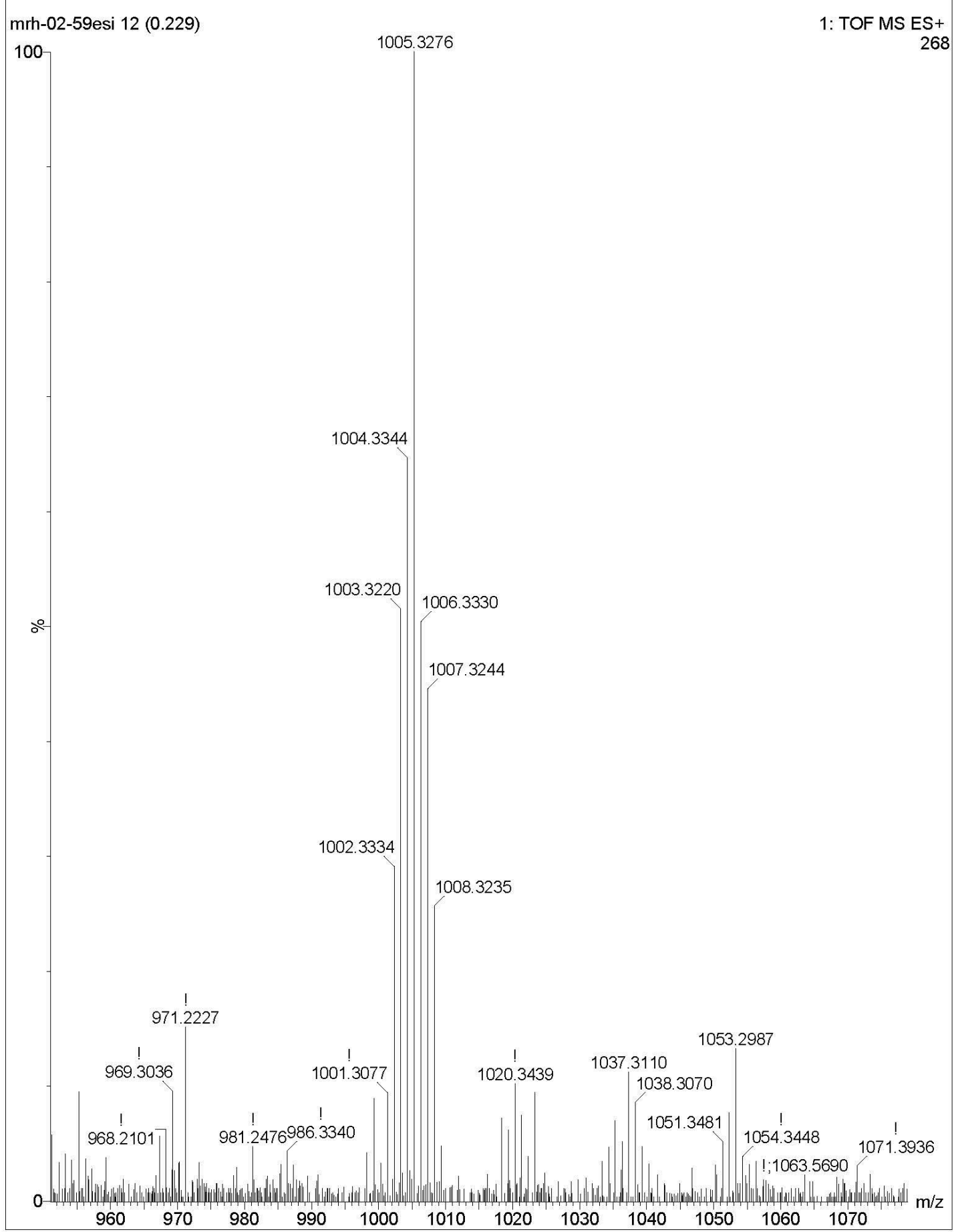

Figure S74. The ESI(+) mass spectrum of $[6 \mathbf{6 b}] \mathrm{BF}_{4}$. 


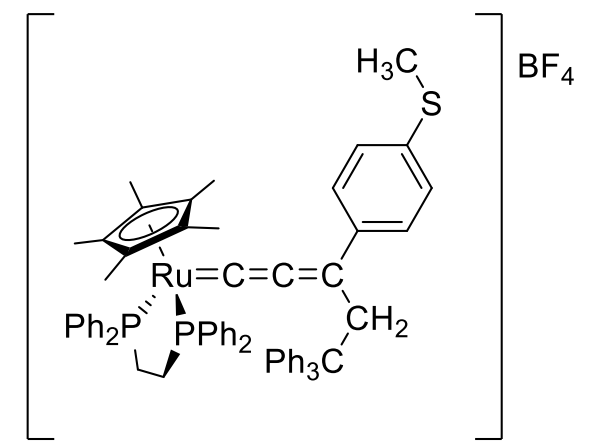

$\left[\mathrm{Ru}\left\{\mathrm{C}=\mathrm{C}=\mathrm{C}\left(\mathrm{CH}_{2} \mathrm{CPh}_{3}\right)\left(4-\mathrm{MeS}-\mathrm{C}_{6} \mathrm{H}_{4}\right)\right\}(\mathrm{dppe}) \mathrm{Cp}^{*}\right] \mathrm{BF}_{4}\left([\mathbf{6 d}] \mathrm{BF}_{4}\right)$
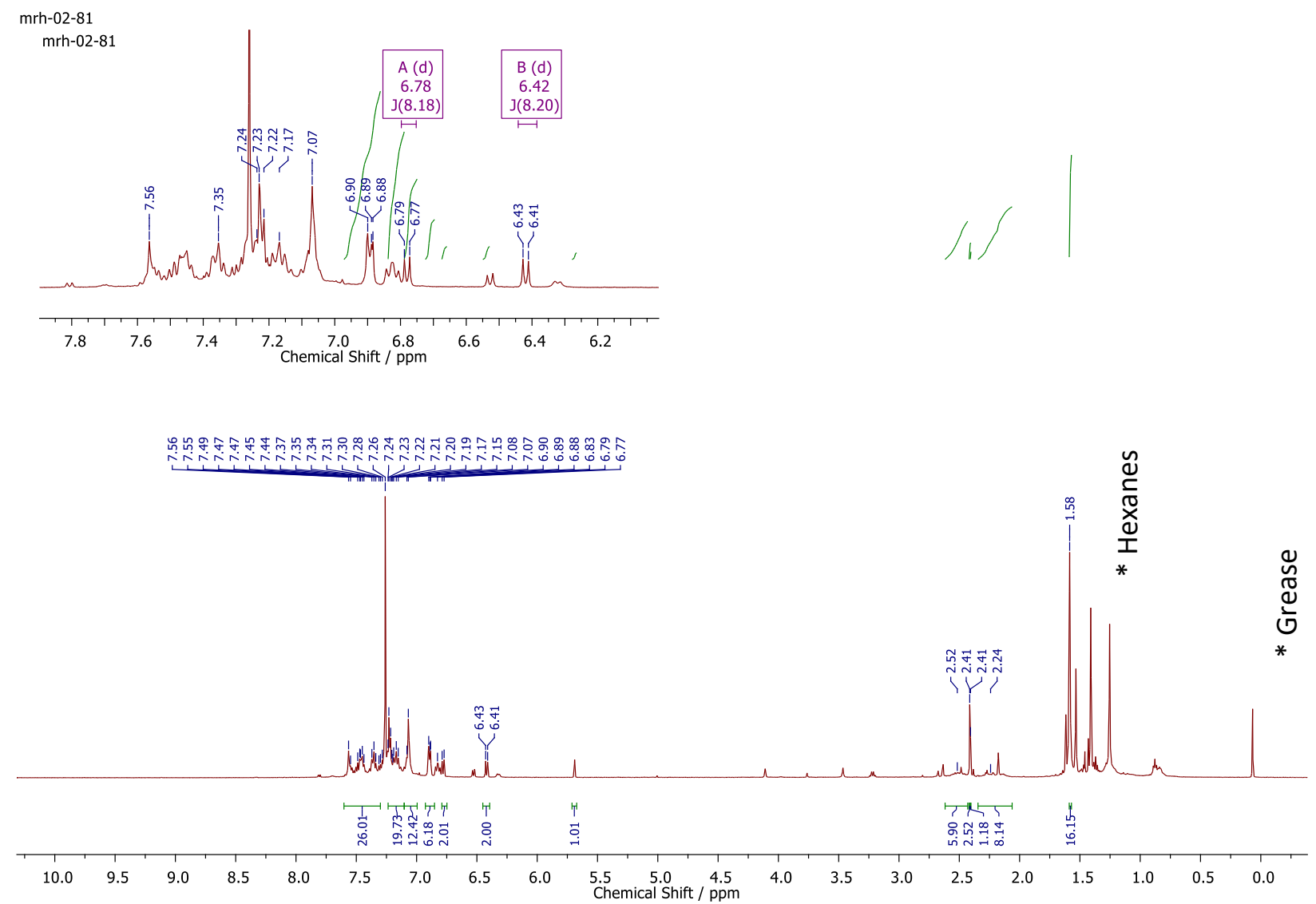

Figure S75. The ${ }^{1} \mathrm{H}$ NMR spectrum of $[\mathbf{6 d}] \mathrm{BF}_{4}$. 


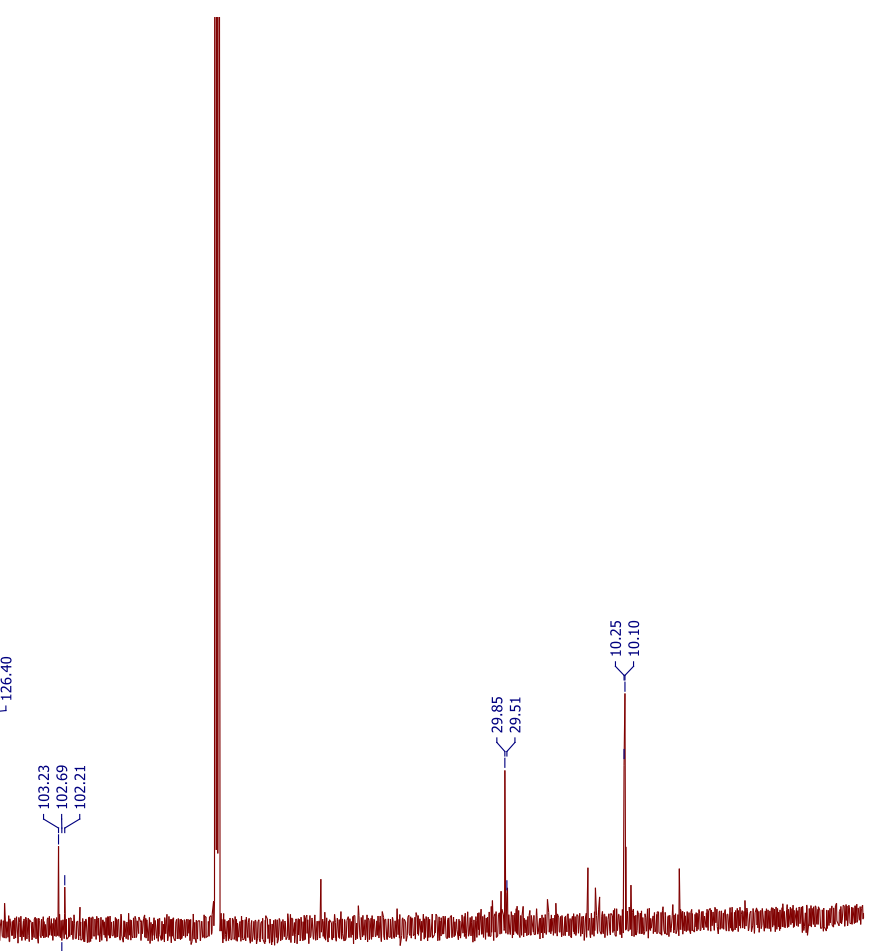

$\begin{array}{lllllllllllllllllllllllll}210 & 200 & 190 & 180 & 170 & 160 & 150 & 140 & 130 & 120 & 110 & 100 & 90 & 80 & 70 & 60 & 50 & 40 & 30 & 20 & 10 & 0 & -10 & -20\end{array}$

Figure S76. The ${ }^{13} \mathrm{C}\left\{{ }^{1} \mathrm{H}\right\} \mathrm{NMR}$ spectrum of $[\mathbf{6} \mathbf{d}] \mathrm{BF}_{4}$. 


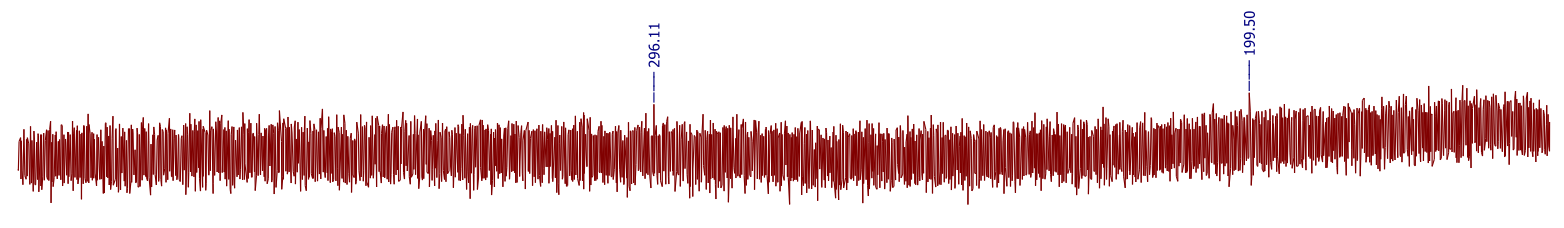

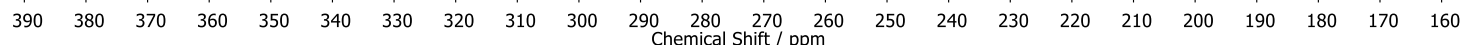

Figure S77. An expansion of the ${ }^{13} \mathrm{C}\left\{{ }^{1} \mathrm{H}\right\}$ NMR spectrum of $[\mathbf{6 d}] \mathrm{BF}_{4}$, showing the allenylidene resonances $C(\alpha)$ and $C(\beta)$. 


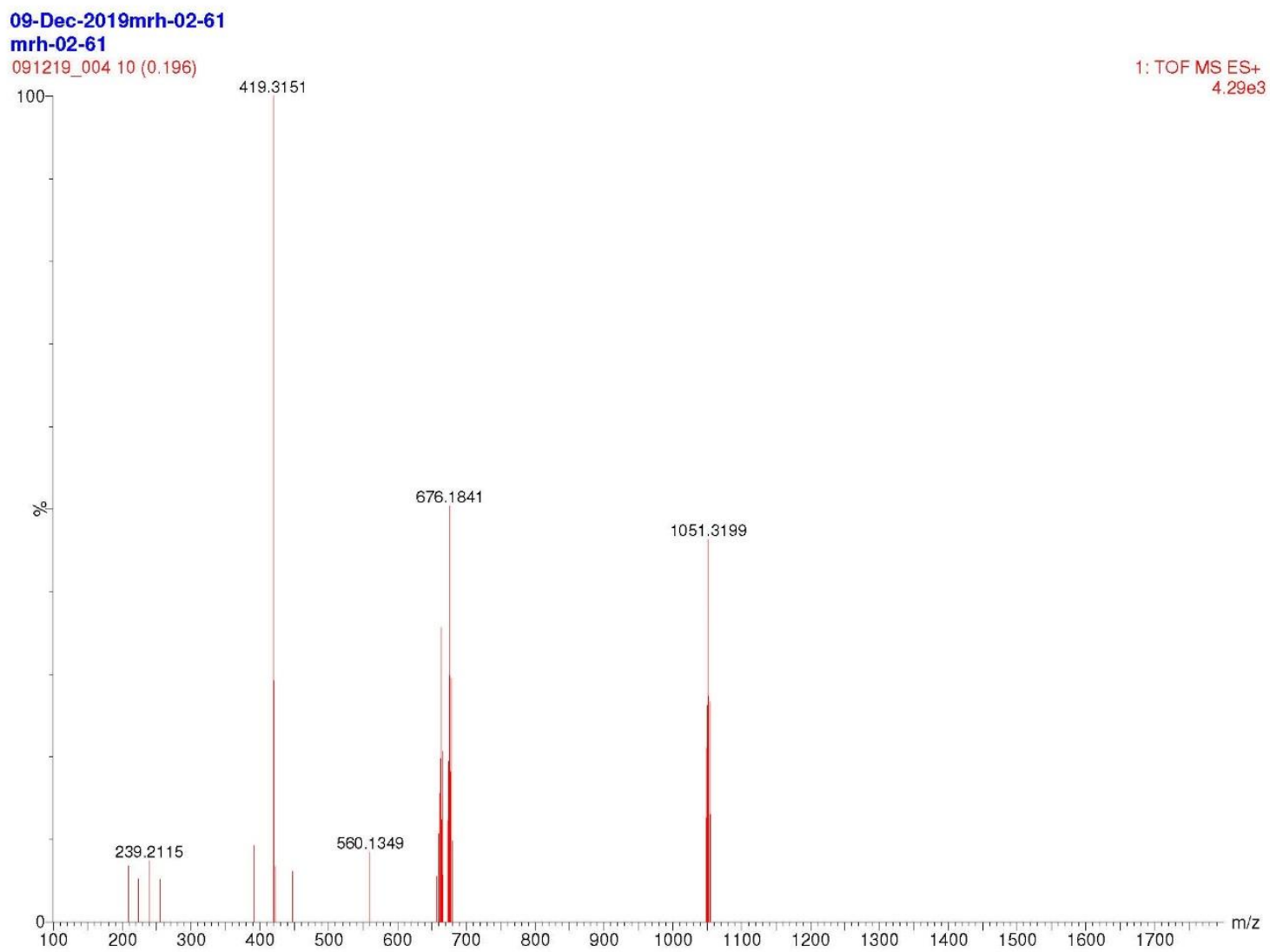

Figure S78. The ESI(+) mass spectrum of $[\mathbf{6 d}] \mathrm{BF}_{4}$. 


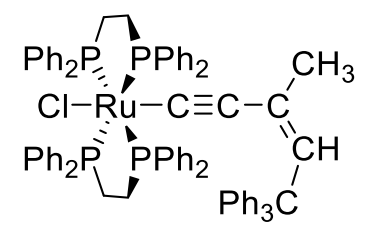

trans $-\left[\mathrm{Ru}\left\{\mathrm{C} \equiv \mathrm{CC}\left(=\mathrm{CHCPh}_{3}\right) \mathrm{Me}\right\} \mathrm{Cl}(\mathrm{dppe})_{2}\right](\mathbf{7 a})$

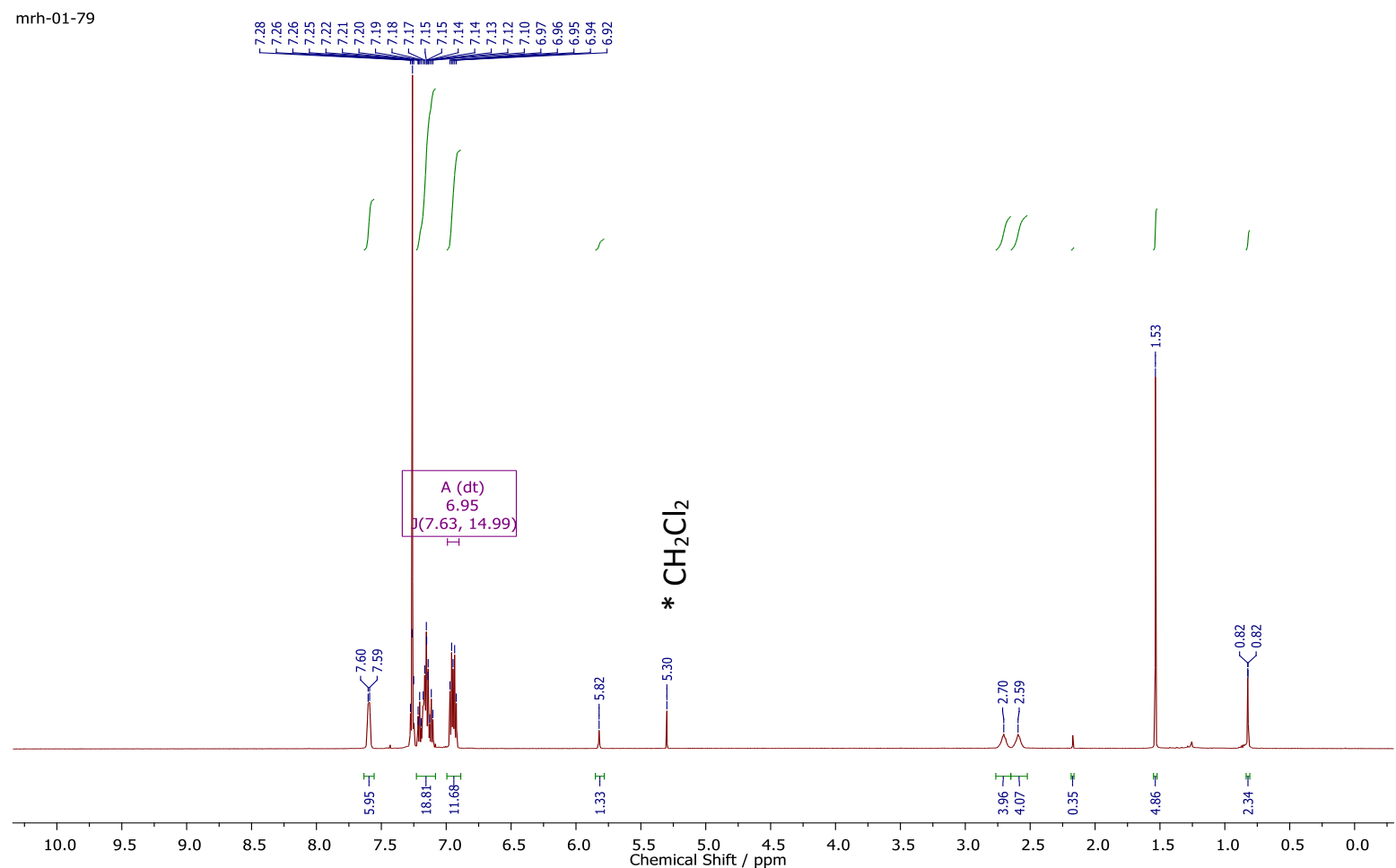

Figure S79. The ${ }^{1} \mathrm{H}$ NMR spectrum of $\mathbf{7 a}$. 

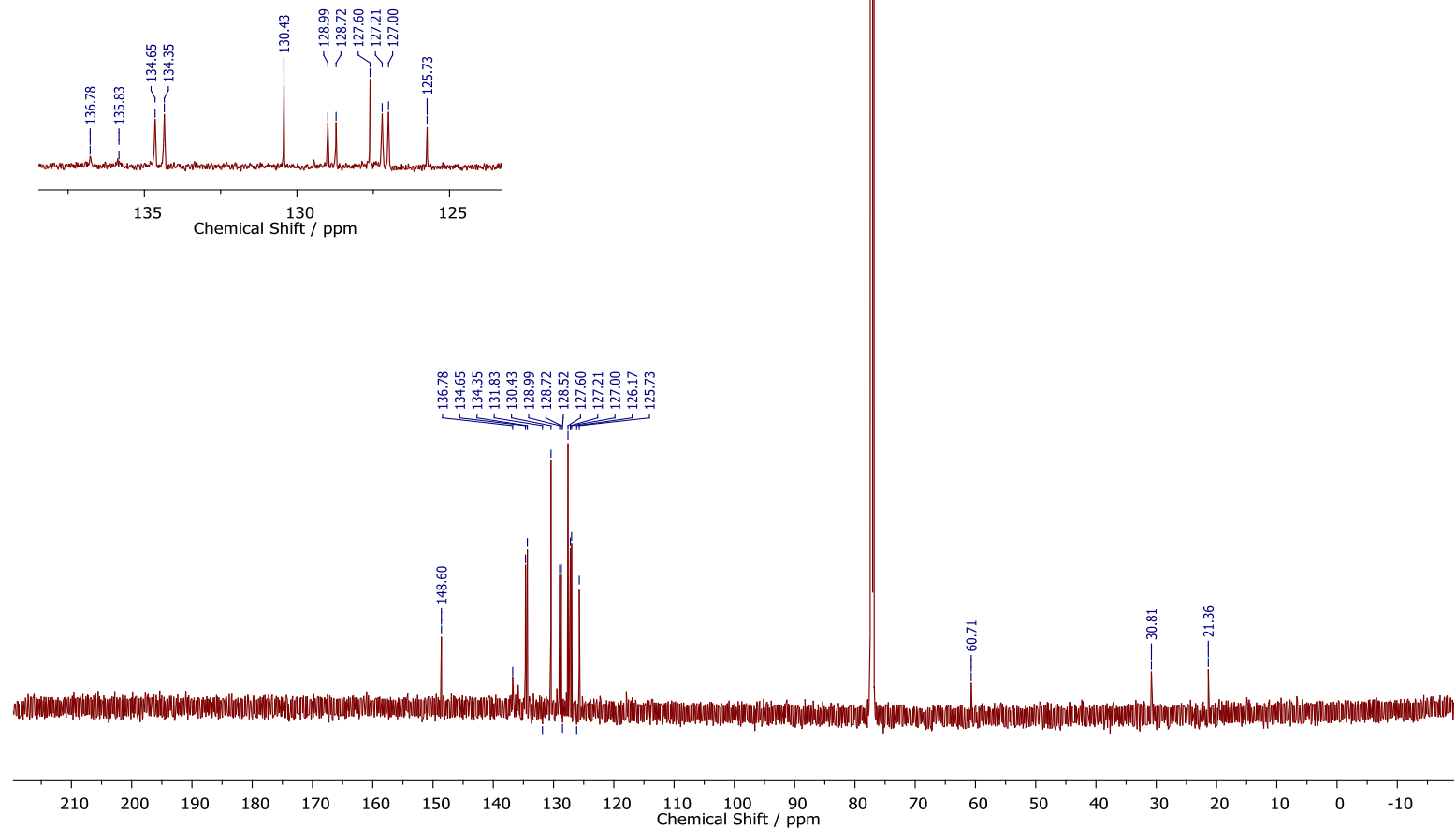

Figure S80. The ${ }^{13} \mathrm{C}\left\{{ }^{1} \mathrm{H}\right\}$ NMR spectrum of 7a. The inset shows an expansion of the aromatic carbon region for clarity 


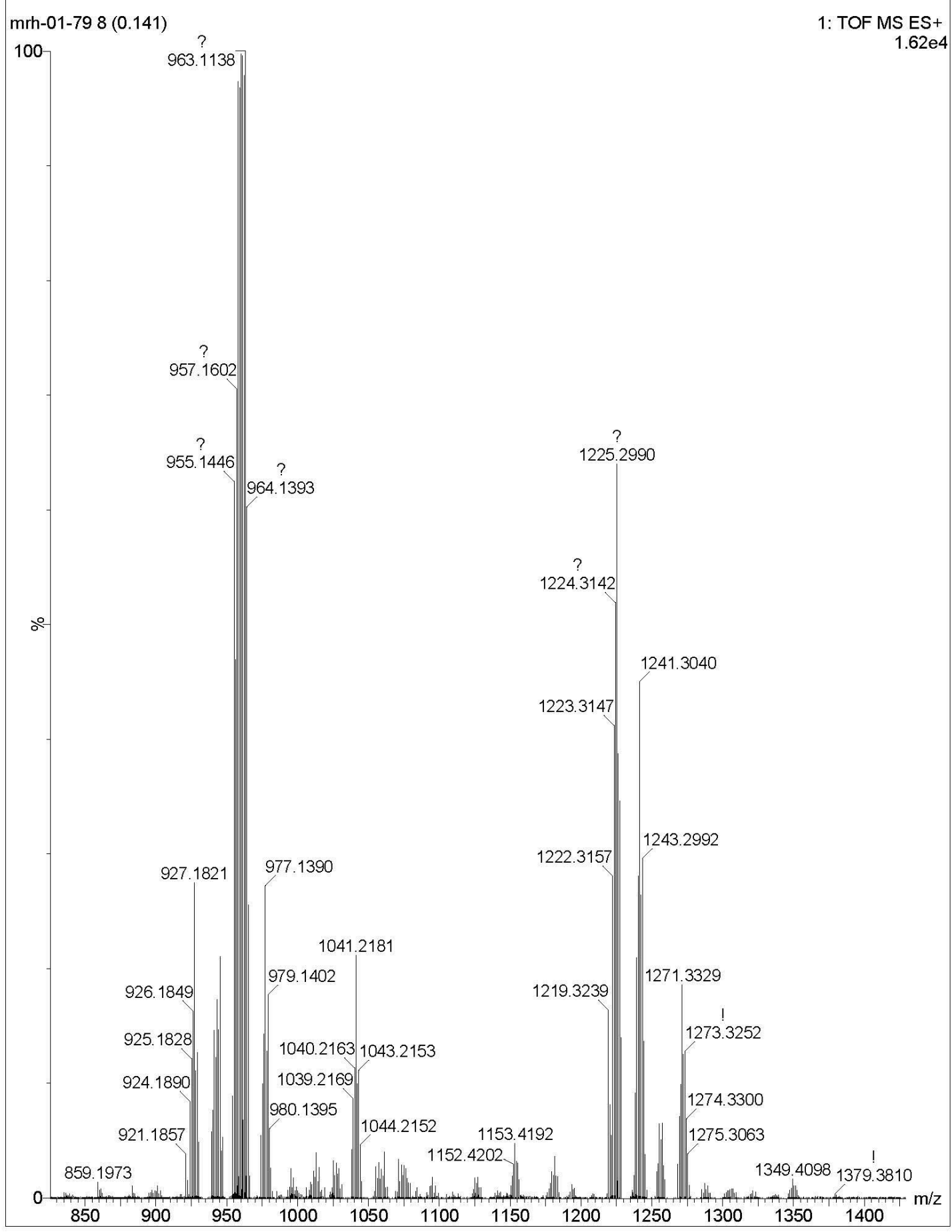

Figure S81. The ESI(+) mass spectrum of 7a. 
Tropylium Addition Products

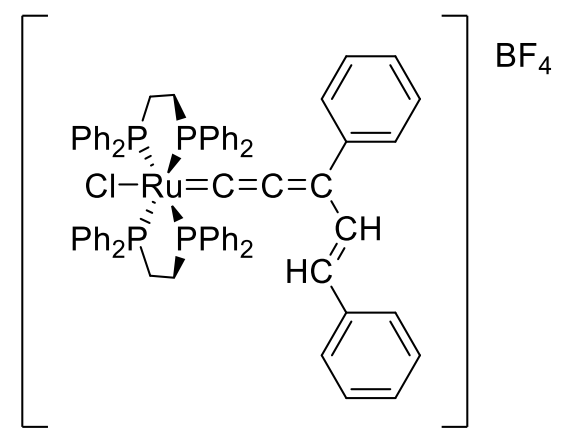

trans $-\left[\mathrm{Ru}\{\mathrm{C}=\mathrm{C}=\mathrm{C}(\mathrm{CH}=\mathrm{CHPh}) \mathrm{Ph}\} \mathrm{Cl}(\mathrm{dppe})_{2}\right] \mathrm{BF}_{4}\left([\mathbf{1 0 b}] \mathrm{BF}_{4}\right)$

mrh-02-30 purple $13 \mathrm{C}$

mrh-02-30 purple $13 \mathrm{C}$

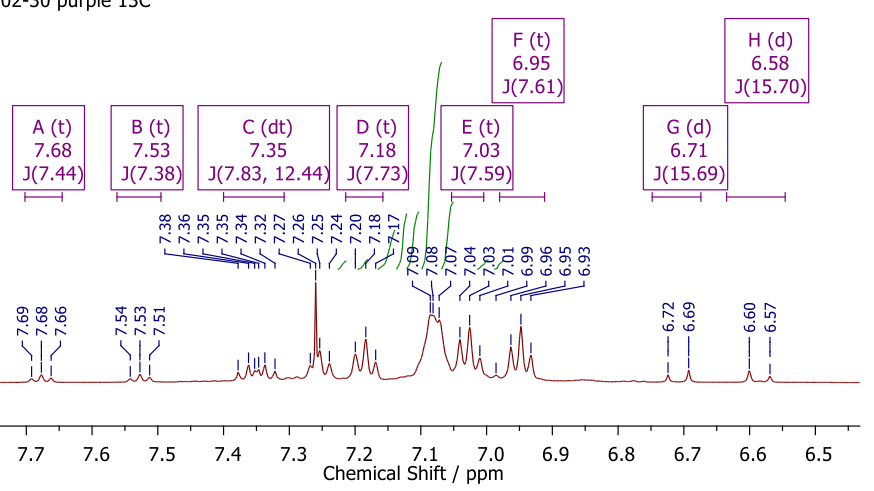

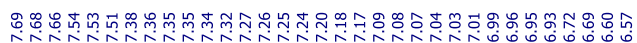

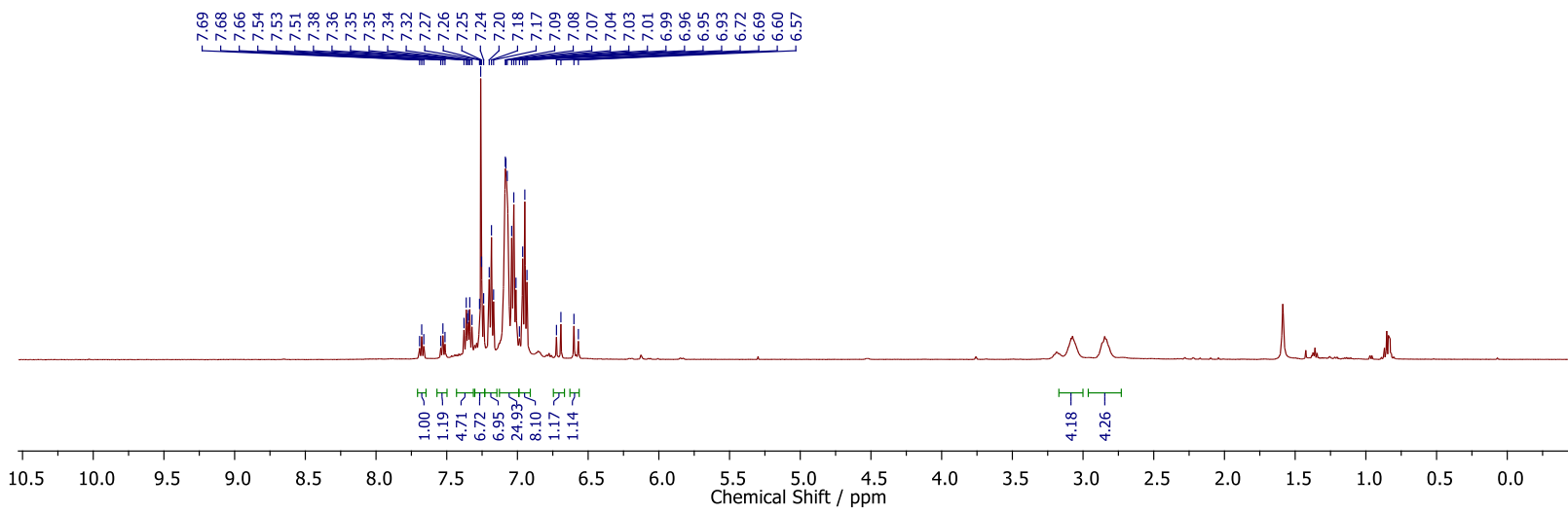

Figure S82. The ${ }^{1} \mathrm{H}$ NMR spectrum of $[\mathbf{1 0 b}] \mathrm{BF}_{4}$. The inset shows an expansion of the aromatic region for clarity. 

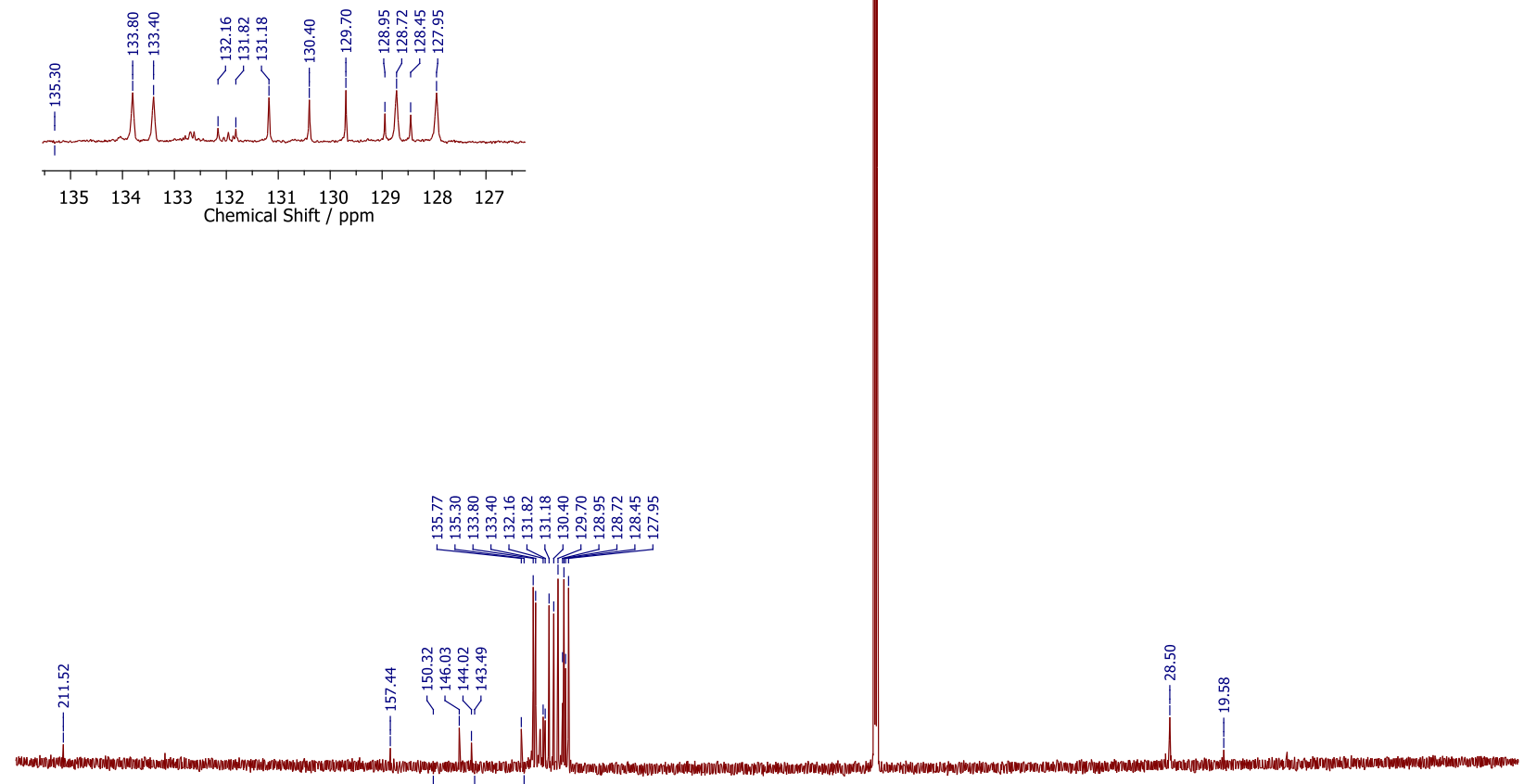

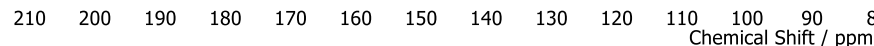

Figure S83. The ${ }^{13} \mathrm{C}\left\{{ }^{1} \mathrm{H}\right\}$ NMR spectrum of $[\mathbf{1 0 b}] \mathrm{BF}_{4}$. The inset shows an expansion of the aromatic carbon region for clarity. 
Figure S84. An expansion of the ${ }^{13} \mathrm{C}\left\{{ }^{1} \mathrm{H}\right\}$ NMR spectrum of $[\mathbf{1 0 b}] \mathrm{BF}_{4}$, showing the allenylidene $C(\alpha), C(\beta)$ and $C(\gamma)$ resonances. 


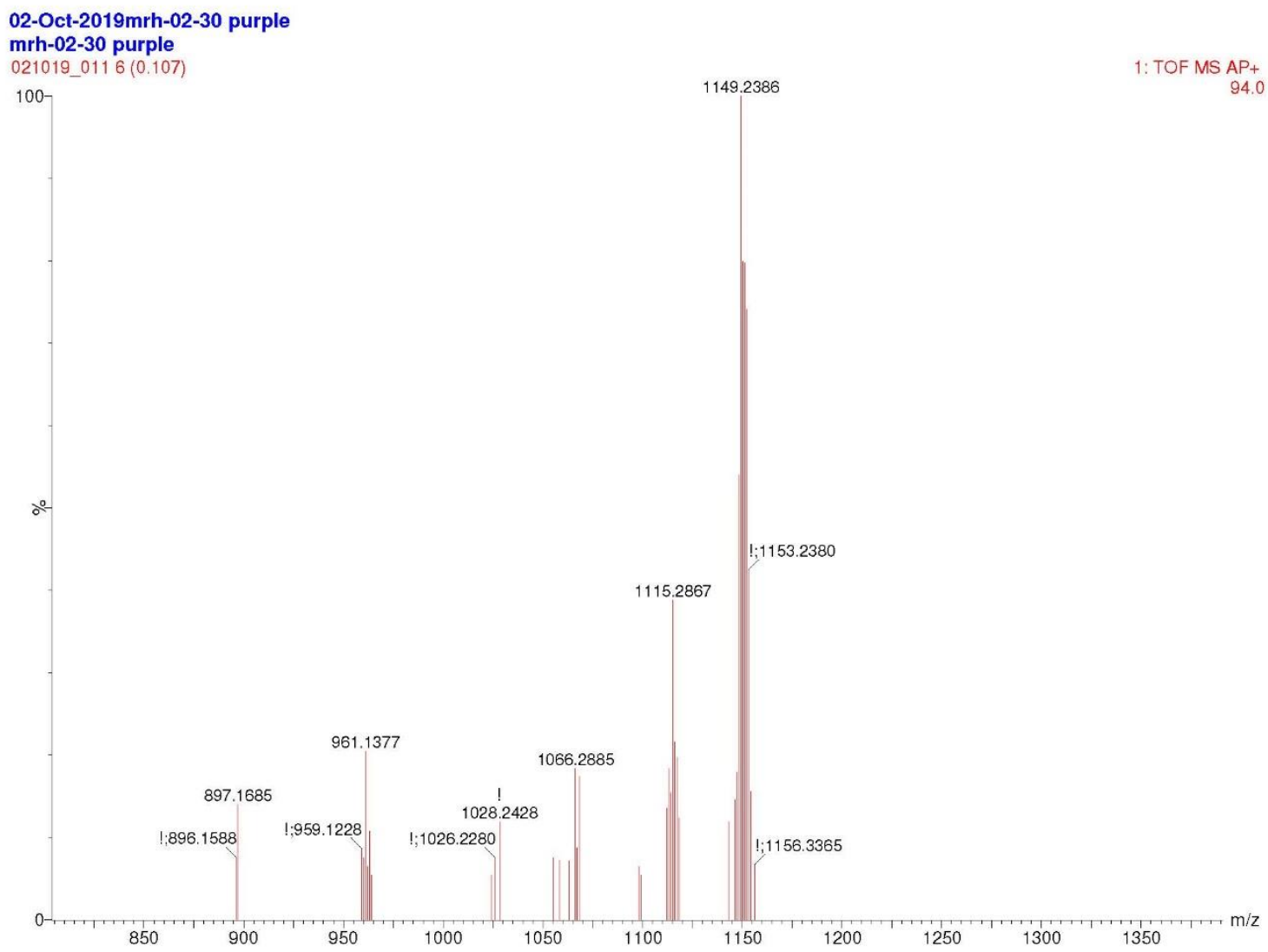

Figure S85. The APCI(+) mass spectrum of $[\mathbf{1 0 b}] \mathrm{BF}_{4}$. 


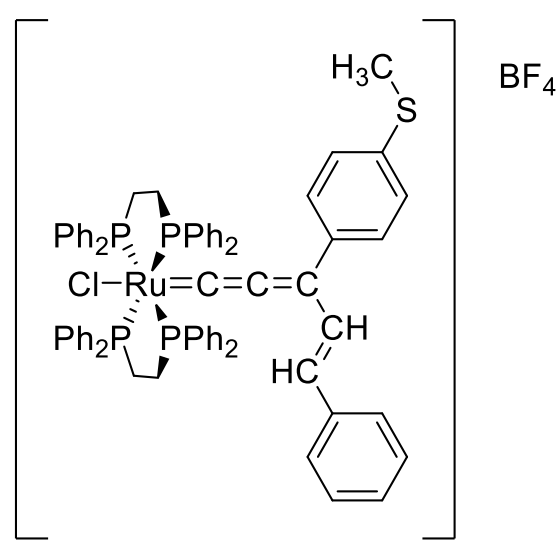

trans $-\left[\mathrm{Ru}\left\{\mathrm{C}=\mathrm{C}=\mathrm{C}(\mathrm{CH}=\mathrm{CHPh})\left(4-\mathrm{MeS}_{-} \mathrm{C}_{6} \mathrm{H}_{4}\right)\right\} \mathrm{Cl}(\mathrm{dppe})_{2}\right] \mathrm{BF}_{4}\left([\mathbf{1 0 d}] \mathrm{BF}_{4}\right)$

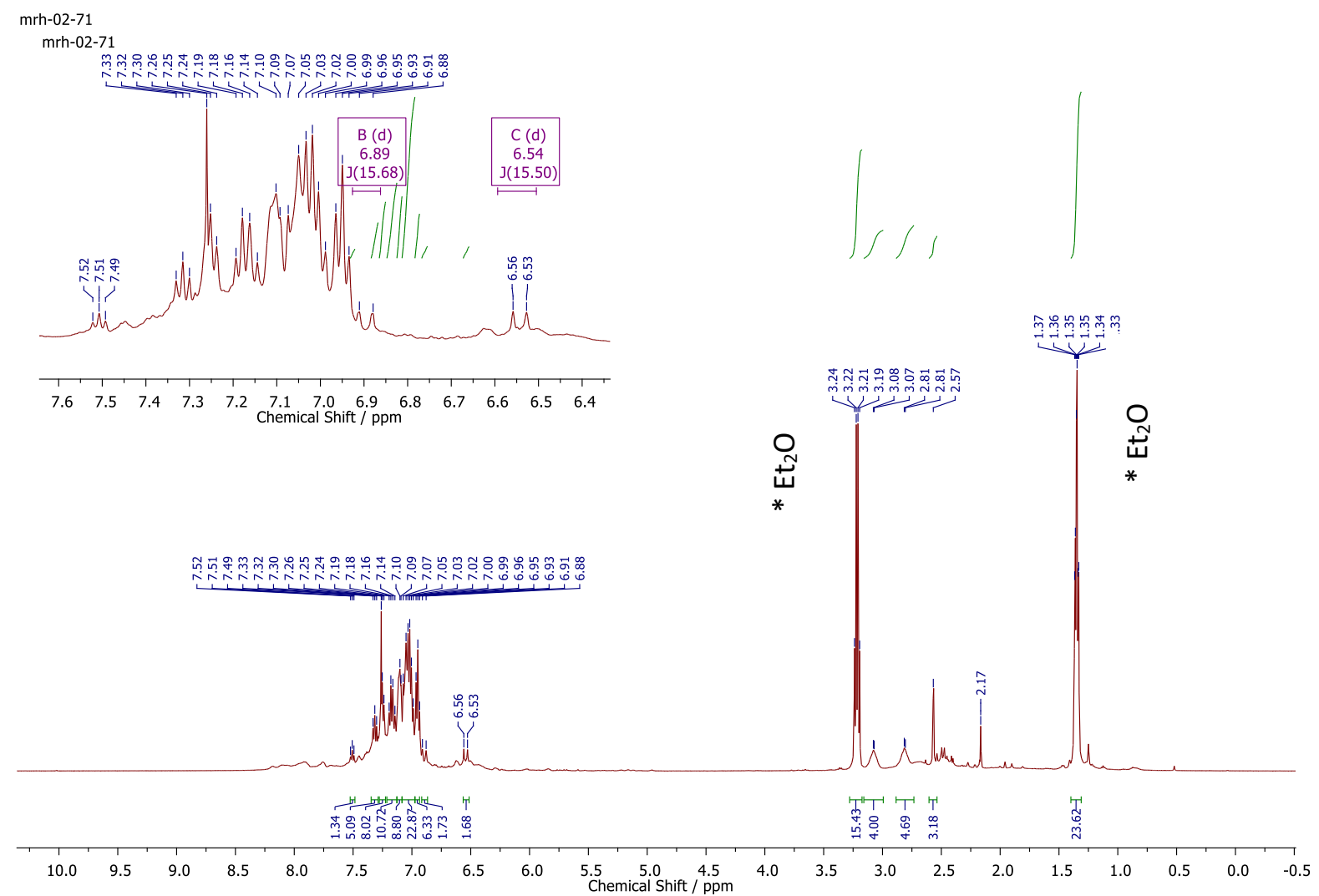

Figure S86. The ${ }^{1} \mathrm{H}$ NMR spectrum of $[\mathbf{1 0 d}] \mathrm{BF}_{4}$. The inset shows an expansion of the aromatic region for clarity. 

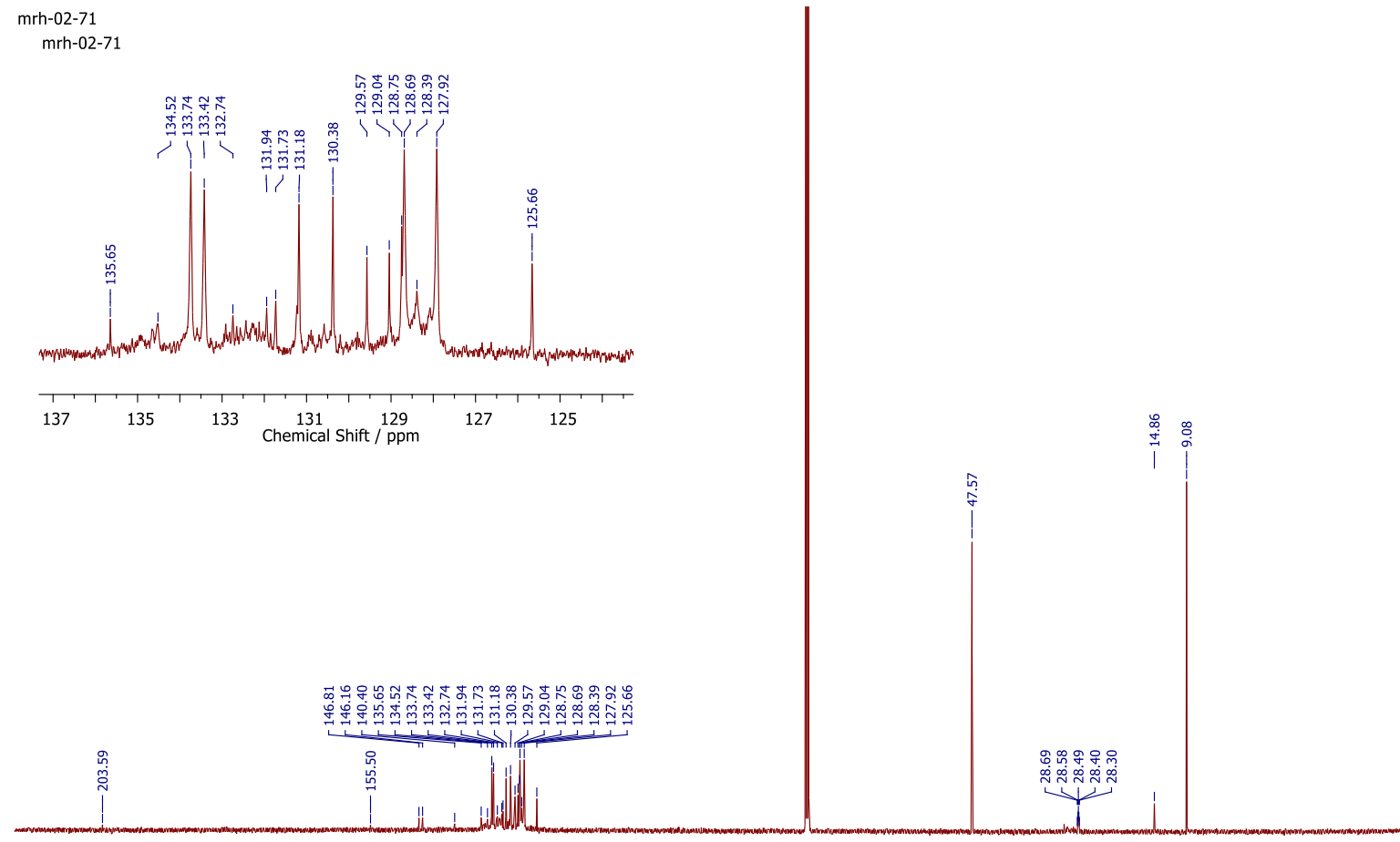

$\begin{array}{lllllllllllllllllllllllll}210 & 200 & 190 & 180 & 170 & 160 & 150 & 140 & 130 & 120 & 110 \begin{array}{c}100 \\ \text { Chemical Shift } / \mathrm{ppm}\end{array} & 70 & 60 & 50 & 40 & 30 & 20 & 10 & 0 & -10 & -20\end{array}$

Figure S87. The ${ }^{13} \mathrm{C}\left\{{ }^{1} \mathrm{H}\right\}$ NMR spectrum of $[\mathbf{1 0 d}] \mathrm{BF}_{4}$. The inset shows an expansion of the aromatic carbon region for clarity. 


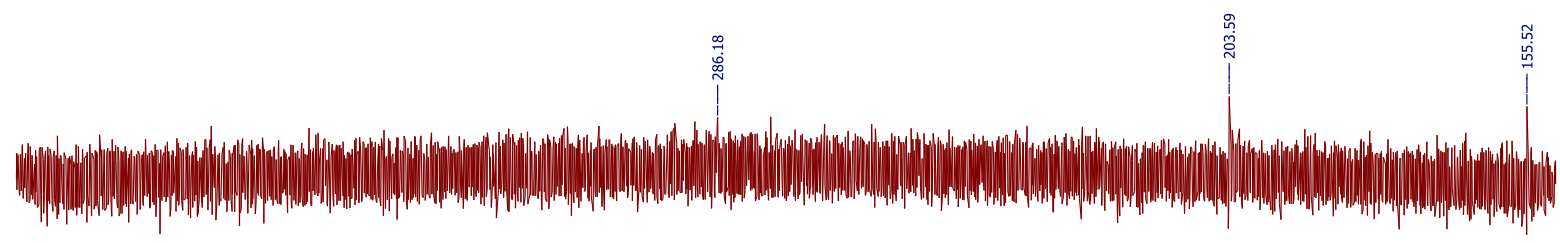

$\begin{array}{lllllllllllllllllllllllllllll}390 & 380 & 370 & 360 & 350 & 340 & 330 & 320 & 310 & 300 & 290 & 280 & 270 & 260 & 250 & 240 & 230 & 220 & 210 & 200 & 190 & 180 & 170 & 160\end{array}$

Figure S88. An expansion of the ${ }^{13} \mathrm{C}\left\{{ }^{1} \mathrm{H}\right\}$ NMR spectrum of $[\mathbf{1 0 d}] \mathrm{BF}_{4}$, showing the allenylidene resonances $C(\alpha), C(\beta)$ and $C(\gamma)$. 


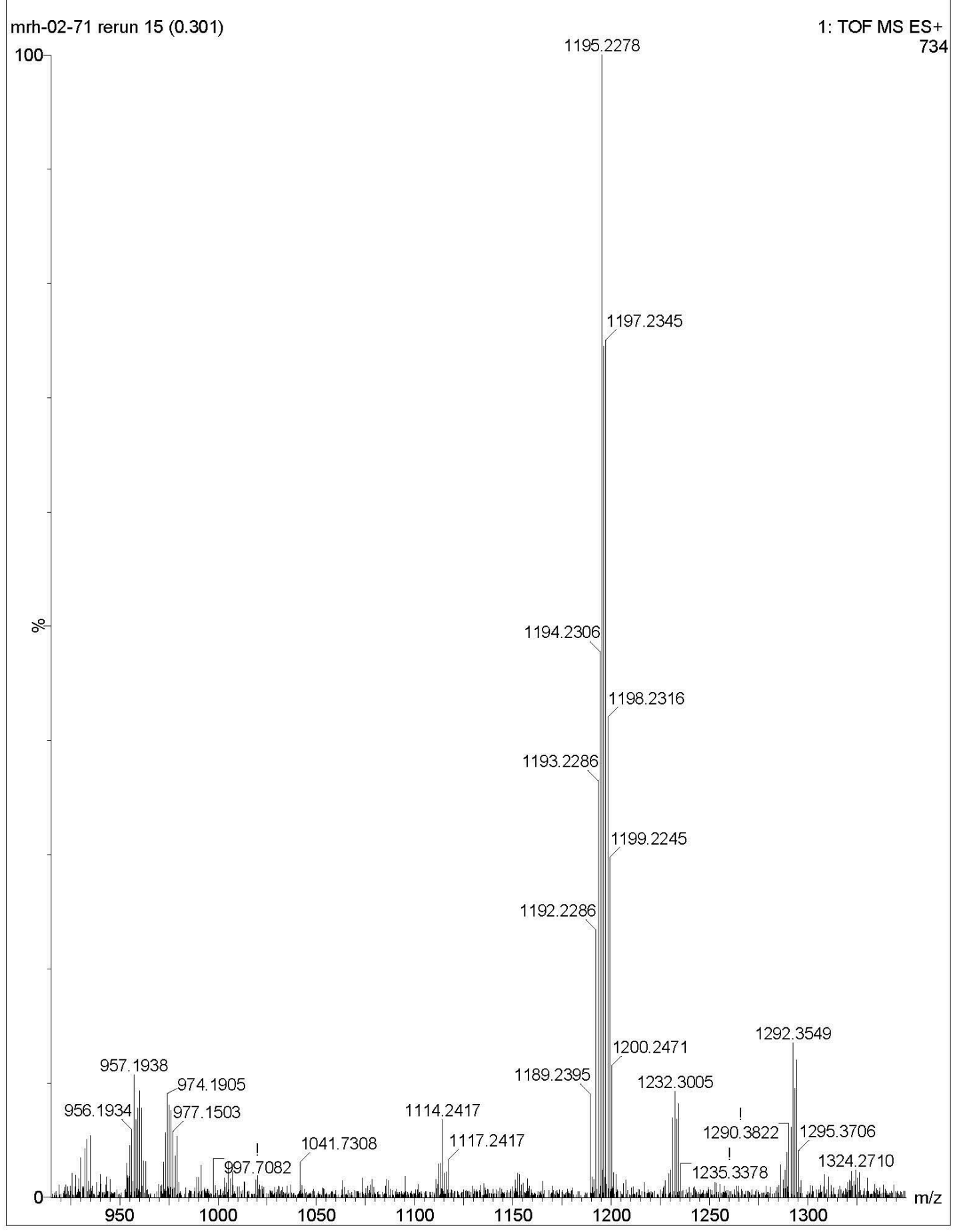

Figure S89. The APCI(+) mass spectrum of $[\mathbf{1 0 d}] \mathrm{BF}_{4}$. 


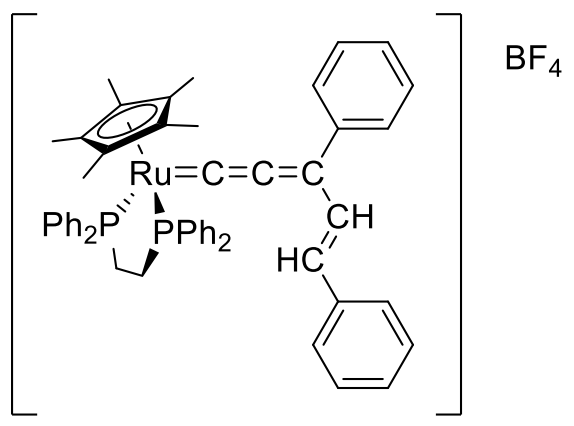

$\left[\mathrm{Ru}\{\mathrm{C}=\mathrm{C}=\mathrm{C}(\mathrm{CH}=\mathrm{CHPh}) \mathrm{Ph}\}(\mathrm{dppe}) \mathrm{Cp}^{*}\right] \mathrm{BF}_{4}\left([\mathbf{1 1 b}] \mathrm{BF}_{4}\right)$

mrh-02-60_400_PROTON_cdcl3_20200219_00

mrhmPR=62-60_400_PROTON_cdcl3_20200219_001

mrh-02-60

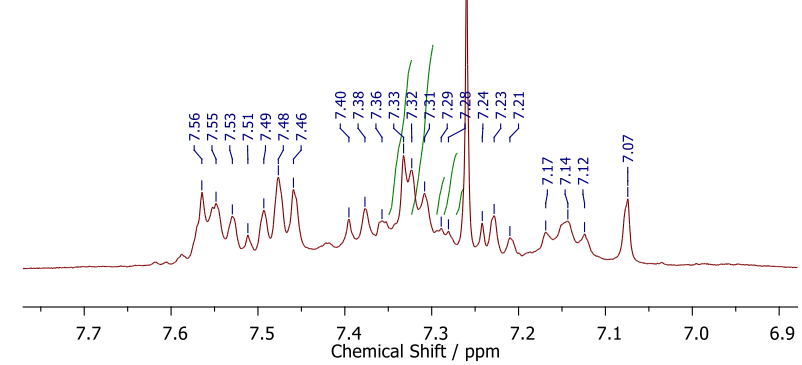

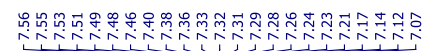

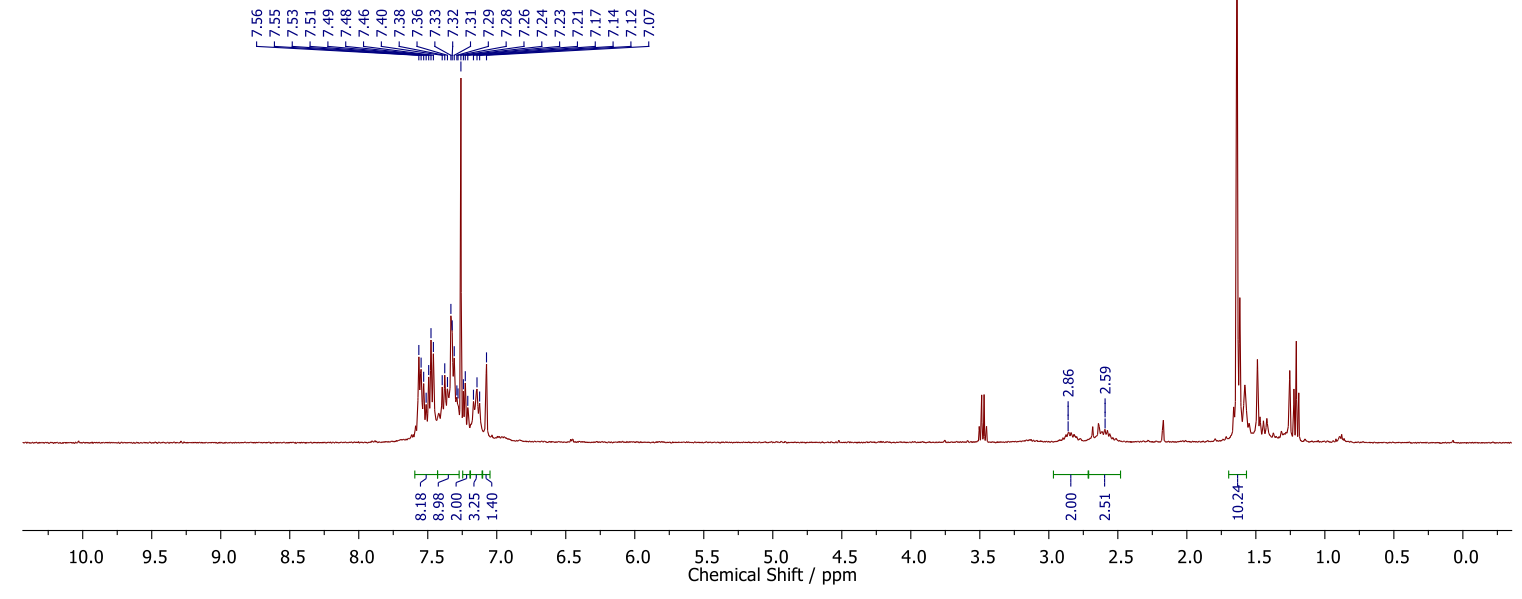

Figure S90. The ${ }^{1} \mathrm{H}$ NMR spectrum of $[\mathbf{1 1 b}] \mathrm{BF}_{4}$. The inset shows and expansion of the aromatic region for clarity. 

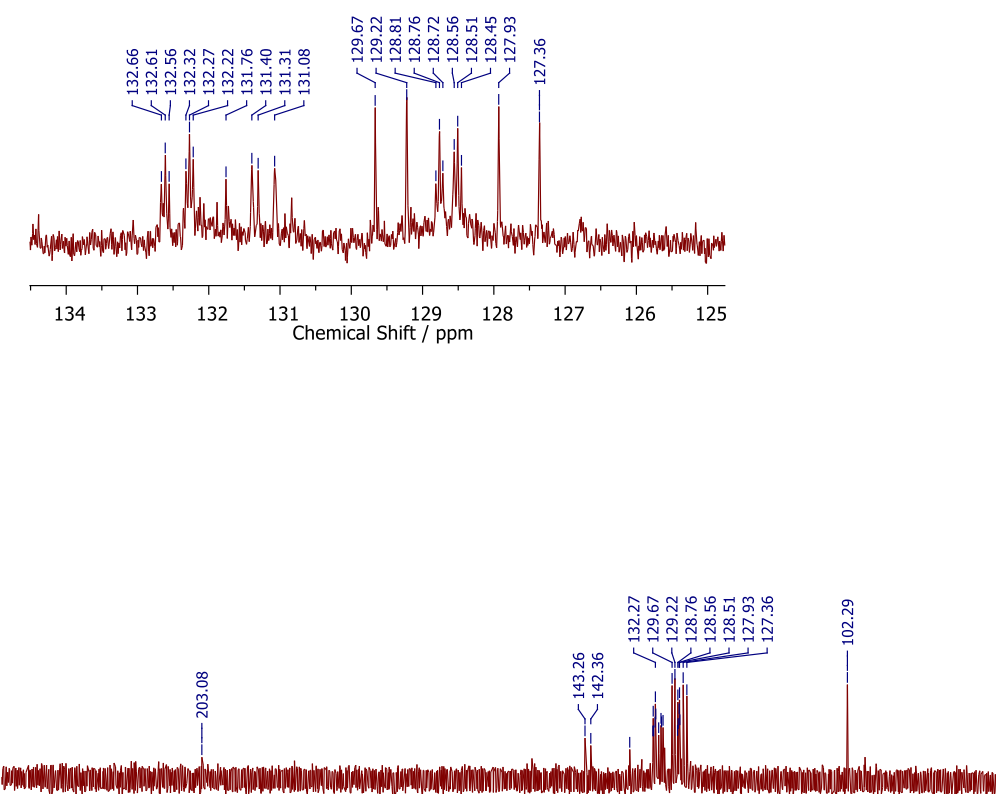

$\begin{array}{lllllllllllllllllllllllll}230 & 220 & 210 & 200 & 190 & 180 & 170 & 160 & 150 & 140 & 130 & 120 & 110 & 100 & 90 & 80 & 70 & 60 & 50 & 40 & 30 & 20 & 10 & 0 & -10\end{array}$

Figure S91. The ${ }^{13} \mathrm{C}\left\{{ }^{1} \mathrm{H}\right\}$ NMR spectrum of $[\mathbf{1 1 b}] \mathrm{BF}_{4}$. The inset shows and expansion of the carbon aromatic region for clarity. 
mrh-02-60_400_CARBON_cdcl3_20200220_001

mrh-02-60

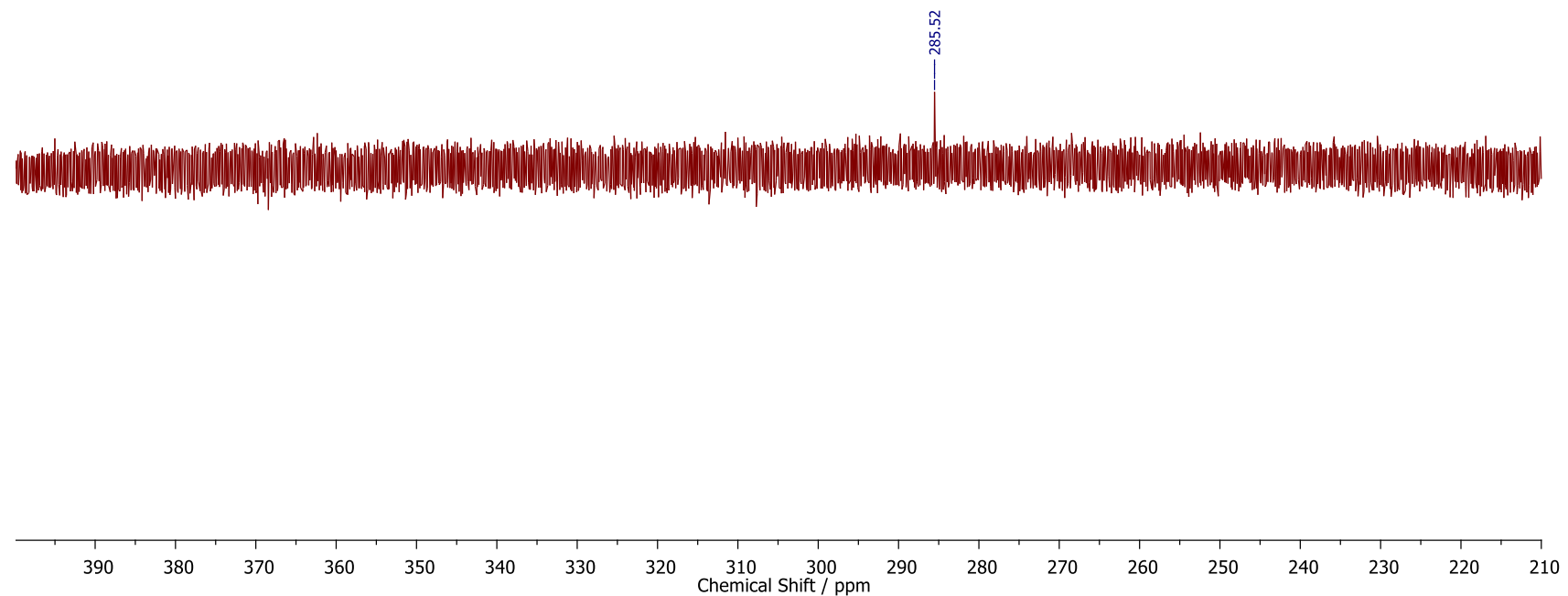

Figure S92. An expansion of the ${ }^{13} \mathrm{C}\left\{{ }^{1} \mathrm{H}\right\}$ NMR spectrum of $[\mathbf{1 1 b}] \mathrm{BF}_{4}$, showing the allenylidene resonance $C(\alpha)$. 


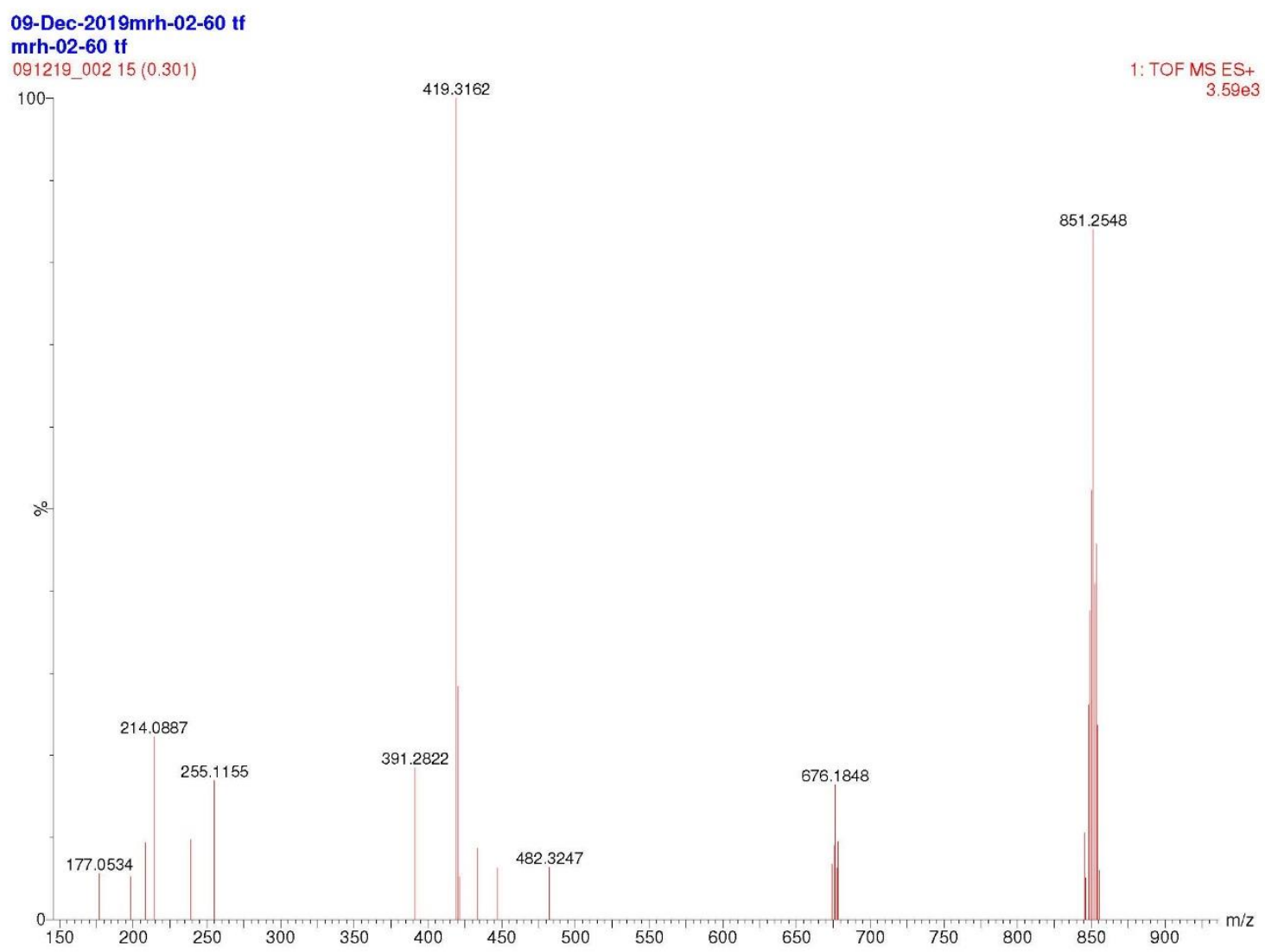

Figure S93. The ESI(+) mass spectrum of $[\mathbf{1 1 b}] \mathrm{BF}_{4}$. 


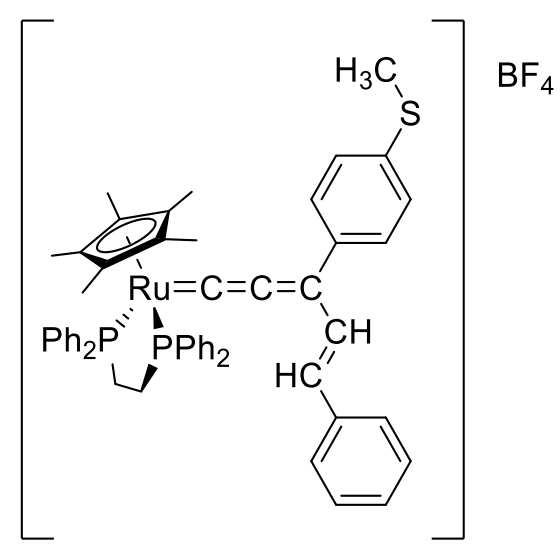

$\left[\mathrm{Ru}\left\{\mathrm{C}=\mathrm{C}=\mathrm{C}(\mathrm{CH}=\mathrm{CHPh})\left(4-\mathrm{MeS}_{-} \mathrm{C}_{6} \mathrm{H}_{4}\right)\right\}(\mathrm{dppe}) \mathrm{Cp}^{*}\right] \mathrm{BF}_{4}\left([\mathbf{1 1 d}] \mathrm{BF}_{4}\right)$

mrh-02-69_bf_400_PROTON_cdcl3_20200227_001

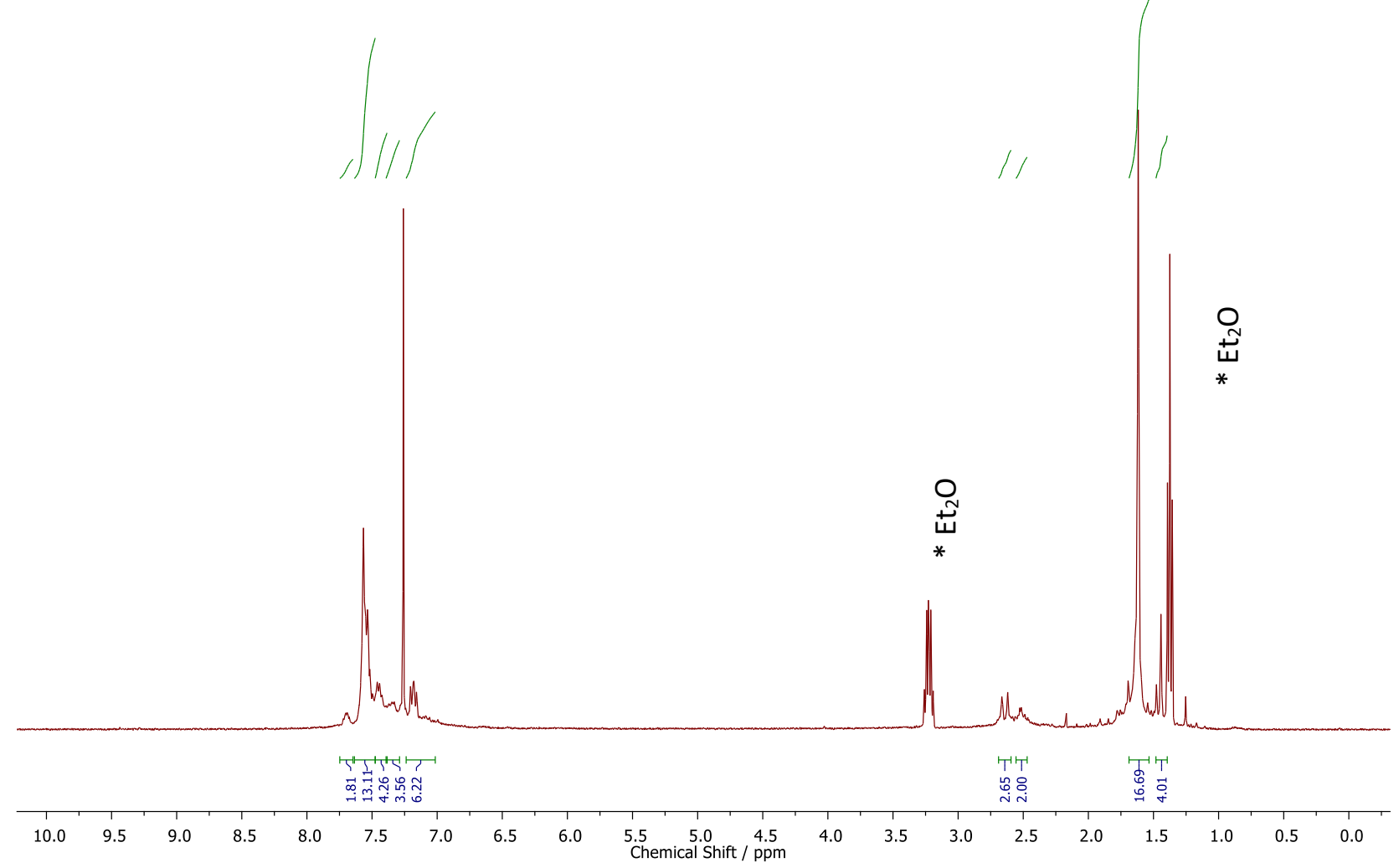

Figure S94. The ${ }^{1} \mathrm{H}$ NMR spectrum of $[\mathbf{1 1 d}] \mathrm{BF}_{4}$. 
mrh-02-69_bf_400_CARBON_cdcl3_20200229_001 $\mathrm{mrh}$ PPR $=62=69$ bf_400_CARBON_cdcl3_20200229_001 mrh-02-69_bf
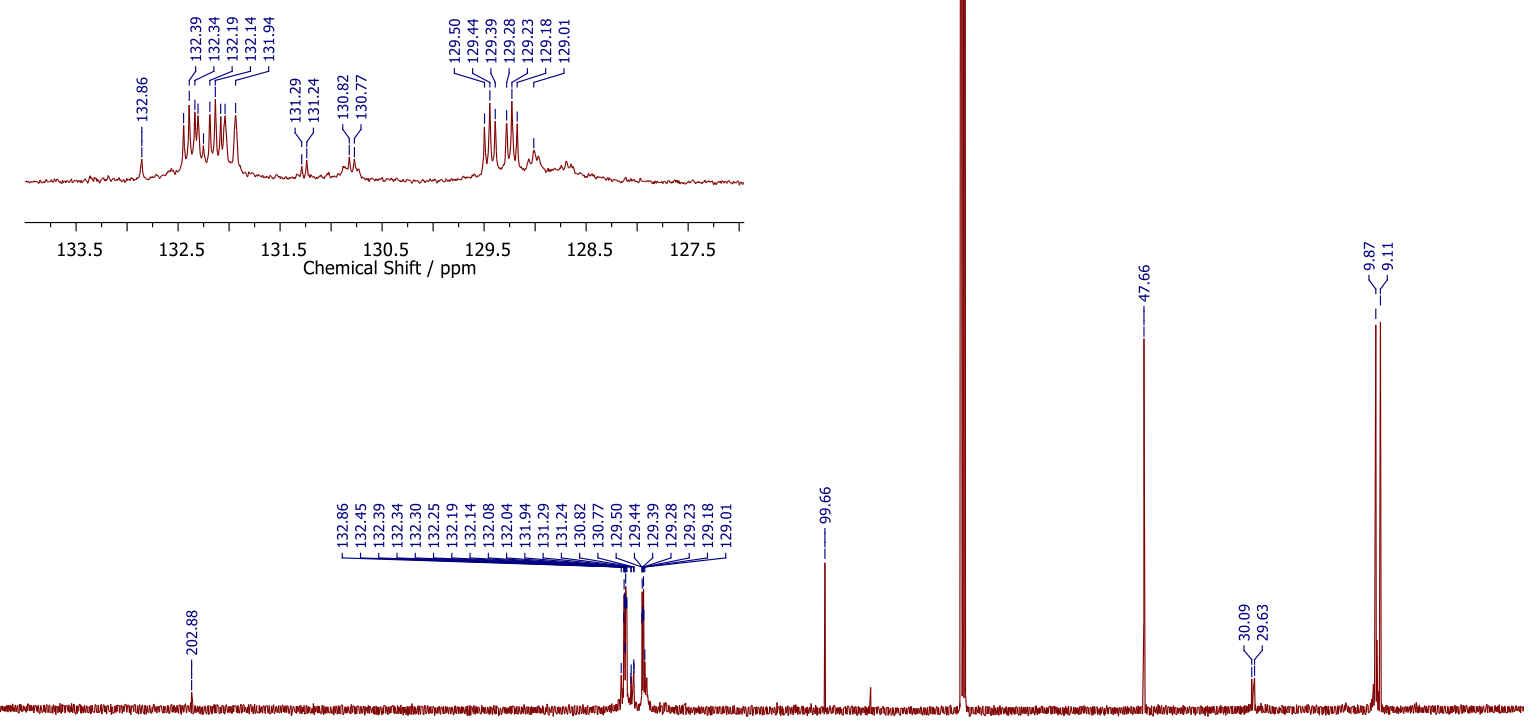

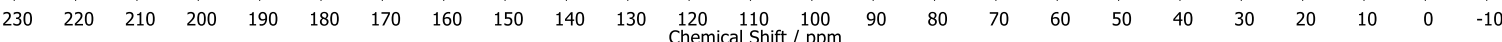

Figure S95. The ${ }^{13} \mathrm{C}\left\{{ }^{1} \mathrm{H}\right\}$ NMR spectrum of $[11 d] \mathrm{BF}_{4}$. 
mrh-02-69_bf_400_CARBON_cdcl3_20200228_001 mrh-02-69_bf

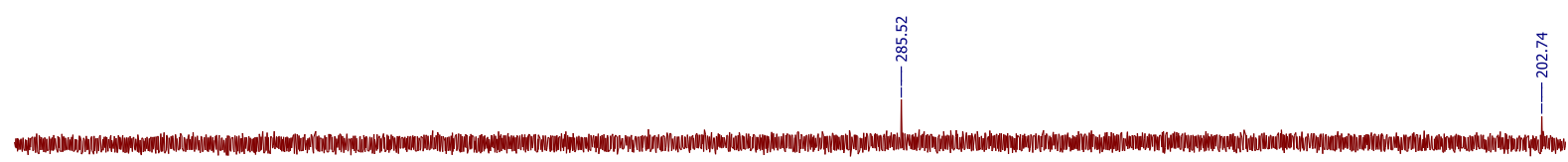

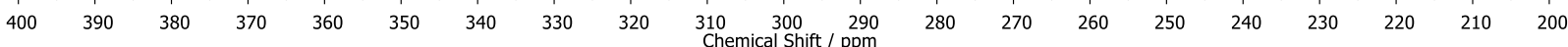

Figure S96. An expansion of the ${ }^{13} \mathrm{C}\left\{{ }^{1} \mathrm{H}\right\}$ NMR spectrum of $[\mathbf{1 1 d}] \mathrm{BF}_{4}$, showing the allenylidene resonances $C(\alpha)$ and $C(\beta)$. 


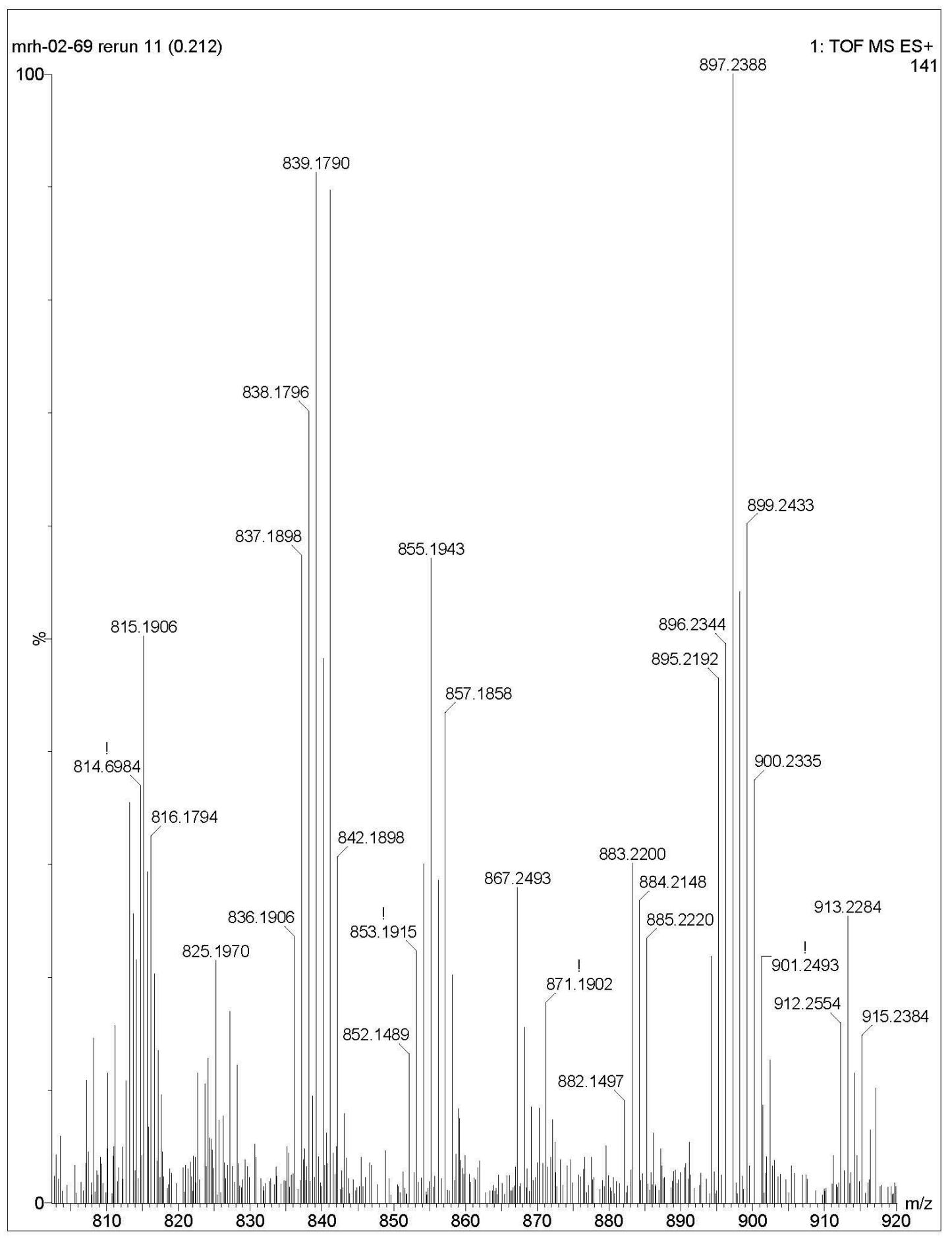

Figure S97. The APCI $(+)$ mass spectrum of $[\mathbf{1 1 d}] \mathrm{BF}_{4}$. 


\section{Crystallographic Data}

D $\left(\mathrm{HC} \equiv \mathrm{CC}(\mathrm{OH})(\mathrm{Me})\left(4-\mathrm{MeS}-\mathrm{C}_{6} \mathrm{H}_{4}\right)\right.$

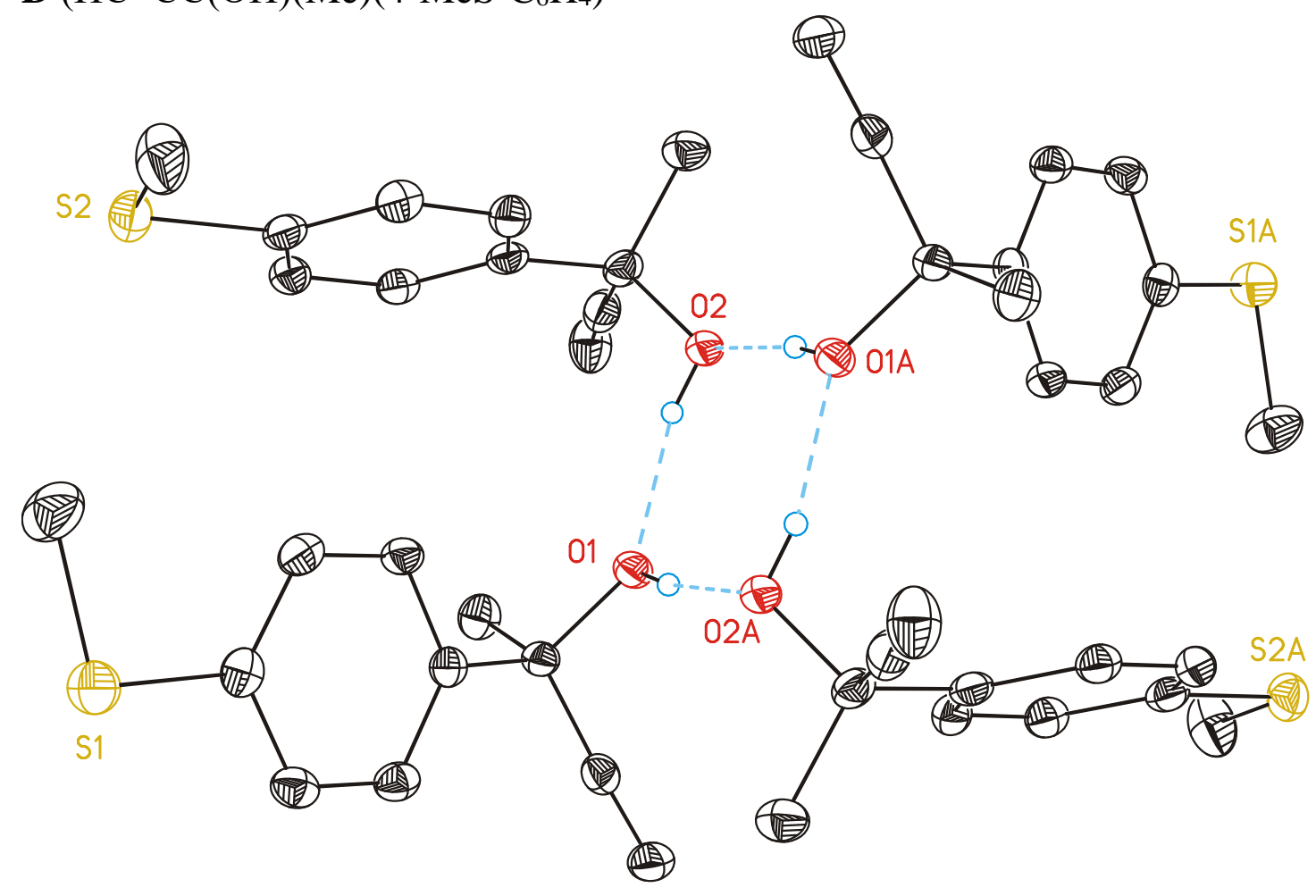

Figure S98. ORTEP drawing (50\% probability level) of the intermolecular hydrogen bond pattern the packing of alkyne D. $(\mathrm{O} 1 \cdots \mathrm{O} 2 \mathrm{~A}=2.7171(18) \AA$; O $2 \cdots \mathrm{O} 1=2.7043(18) \AA$; O1$\mathrm{H} 1 \mathrm{~A} \cdots \mathrm{O} 2=172^{\circ}$; O2-H2 $\cdots \mathrm{O} 1=162^{\circ}$; Symmetry operation: $\left.(\mathrm{A})=-\mathrm{x}, 2-\mathrm{y},-1-\mathrm{z}.\right)$ 